\title{
A new genus of Chamaemyiidae (Diptera: Lauxanioidea) predaceous on Adelgidae (Hemiptera), with a key to chamaemyiid species associated with Pinaceae-feeding Sternorrhyncha
}

\author{
STEPHEN D. GAIMARI ${ }^{1} \&$ NATHAN P. HAVILL ${ }^{2}$ \\ ${ }^{I}$ California State Collection of Arthropods, California Department of Food \& Agriculture, Plant Pest Diagnostics Branch, 3294 \\ Meadowview Road, Sacramento, California 95832-1448, USA. "sgaimari@gmail.com; (1) https://orcid.org/0000-0002-4240-7154 \\ ${ }^{2}$ United States Department of Agriculture - Forest Service, Northern Research Station, 51 Mill Pond Road, Hamden, Connecticut \\ 06514, USA. |=" nathan.p.havill@usda.gov; @ https://orcid.org/0000-0002-4004-8266
}

\begin{abstract}
A new genus of Chamaemyiidae (Diptera: Lauxanioidea) is described, namely Leucotaraxis gen. nov. (type species Leucopis atrifacies Aldrich; other included species Leucotaraxis argenticollis (Zetterstedt), comb. nov., Leucotaraxis piniperda (Malloch), comb. nov., and Leucotaraxis sepiola sp. nov.). These species are predators of Adelgidae (Hemiptera) infesting Pinaceae. Leucotaraxis argenticollis is Holarctic, while the other three species are Nearctic. The phylogeny of Leucotaraxis with other representatives of Chamaemyiidae was elucidated using mitochondrial and nuclear DNA sequences and the genus was found to be monophyletic. Egg and puparial stages are discussed or described and illustrated for all species except Leucotaraxis sepiola. A key is provided to all species of Chamaemyiidae known to attack Pinaceaeinfesting Sternorrhyncha, an annotated list of these taxa is provided, and a habitus photograph is provided for each genus with such species. In addition, a lectotype is designated for Leucopis olivacea Meijere, and it is synonymized under Neoleucopis obscura (Haliday), syn. nov.
\end{abstract}

Key words: new genus, new species, key, lectotype, new combinations, new synonym, immature stages, silver fly

\section{Introduction}

Chamaemyiidae (Diptera), or silver flies, represents a group of larval predators attacking sternorrhynchus Hemiptera, such as aphids, adelgids, scale insects, and mealybugs. Although the species of some chamaemyiid genera are quite general in their feeding habits, many genera are restricted to a particular sternorrhynchan prey lineage. There are currently 32 described genera and subgenera of Chamaemyiidae worldwide, with more than 340 valid species. The vast majority of species-level work has been undertaken in the Palearctic Region (e.g., Tanasijtshuk 1986). For the New World fauna, few comprehensive treatments have been published. Tanasijtshuk (2002) summarized the Nearctic species of Leucopis Meigen, published before 1965, and then Tanasijtshuk (2003, 2005, 2006) proceeded to describe 21 new species of Leucopis from this part of the world, leaving many more still in need of description, and with no keys to species. The Chamaemyiidae chapter (Gaimari 2010) in the second volume of the Manual of Central American Diptera includes a key to all New World genera. This paper serves to make available one of the recognized new genera (Leucotaraxis gen. nov., indicated there as "Undescribed Genus C") in that work, with several new combinations and one new species. One of the other undescribed genera from South America in that work (undescribed genus A) was described as Chamaeleucopis Gaimari (Gaimari 2012), and two others (undescribed genera B and D) were recently described as Vitaleucopis Gaimari and Chamaethrix Gaimari, respectively (Gaimari 2020).

The biology of species of Chamaemyiidae was reviewed by Gaimari (2010, 2021). A review of the use of chamaemyiids for biological control of adelgids was provided by Ross et al. (2011) and Gaimari (2021). Examples of adelgids that serve as prey for chamaemyiids in their native ranges include the balsam woolly adelgid, Adelges piceae (Ratzeburg) (Eichhorn 1968) and the pine adelgid, Pineus pini (Goeze) (Wilson 1938) in Europe, the fir 
adelgids A. knucheli Schneider-Orelli \& Schneider and A. joshii Schneider-Orelli \& Schneider in the Himalayas (Rao \& Ghani 1972), and the pine bark adelgid, Pineus strobi (Hartig), in eastern North America (Sluss \& Foote 1973; Wantuch et al. 2019). Chamaemyiids have been evaluated for introduction as biological control agents for several exotic adelgid species. In fact, the only instances of successful biological control of adelgids utilized chamaemyiids from Europe: Pineus boerneri Annand was regulated below economically injurious levels in pine plantations in Chile with Neoleucopis obscura (Haliday) (Mills 1990); and P. pini was controlled in Hawaii with N. obscura (Culliney et al. 1988) and in New Zealand with N. tapiae (Blanchard) (Zondag \& Nuttall 1989). Two species of Leucotaraxis discussed here, L. argenticollis (Zetterstedt) and L. piniperda (Malloch), are being evaluated as biological control agents of the hemlock woolly adelgid, Adelges tsugae Annand (Kohler et al. 2008; Grubin et al. 2011; Ross et al. 2011; Motley et al. 2017; Neidermeier et al. 2020; Dietschler et al. 2021). Additional details on the biology of chamaemyiids attacking Pinaceae-feeding Sternorrhyncha are provided herein, along with the description of Leucotaraxis gen. nov. containing four species, one of which is new. The four species are described or rediagnosed herein (noting that full descriptions of three of the species are in McAlpine \& Tanasijtshuk (1972) and Tanasijtshuk (2002)), and the phylogeny of Leucotaraxis, in context with other representatives of Chamaemyiidae, was elucidated using mitochondrial and nuclear DNA sequences. A key is provided to all known chamaemyiid species attacking Pinaceae-feeding Sternorrhyncha, as well as an annotated list of these species.

\section{Materials and methods}

Many specimens for this study were collected or reared by the authors and various colleagues (Table 1 contains the names of collectors for those specimens used in the molecular aspects of this work, for the Leucotaraxis species and the other included taxa). Additional material was provided from several insect collections, some of which maintain types for species included in this work, including: California Academy of Sciences, San Francisco, California, USA (CAS); California State Collection of Arthropods, Sacramento, California, USA (CSCA) and its associated Frozen Tissue Collection (CSCA-FTC); Canadian National Collection of Insects, Arachnids \& Nematodes, Agriculture \& Agri-Food Canada, Ottawa, Ontario, Canada (CNC); Cornell University Insect Collection, Ithaca, New York, USA (CUIC); Illinois Natural History Survey, Urbana, Illinois, USA (INHS); Lund University Museum of Zoology, Lund, Sweden (MZLU); Pacific Forestry Centre Arthropod Reference Collection, Canadian Forest Service, Victoria, British Columbia, Canada (PFCA); Collection Entomologique Ouellet-Robert, Université de Montréal, Montréal, Québec, Canada (QMOR); University of Arizona Insect Collection, Tucson, Arizona, USA (UAIC); National Museum of Natural History, Washington, DC, USA (USNM); and Peabody Museum of Natural History, Yale University, New Haven, Connecticut, USA (YPM). Additional collections housing types cited herein include: Dipartimento di Coltivazione e Difesa delle Specie Legnose, Sezione Entomologia Agraria, Università di Pisa, Italy (DCDS); Hungarian Natural History Museum, Budapest, Hungary (HNHM); Bangalore Biological Control Research Institute - Entomology, Bangalore, India (ICPR); Museo Argentino de Ciencias Naturales "Bernardino Rivadavia", Buenos Aires, Argentina (MACN); Museo di Zoologia, Univerità di Bologna, Italy (MZUB); Naturhistorisches Museum Wien, Vienna, Austria (NHMW); National Museum of Ireland, Dublin, Ireland (NMID); Zoological Institute, Russian Academy of Sciences, Saint Petersburg, Russia (ZISP); and Zoologisch Museum - Entomology, Instituut voor Taxonomische Zoologie, Universiteit van Amsterdam, Amsterdam, Netherlands (ZMAN).

For all specimens where abdomens were dissected and macerated using lactic acid, the partial abdomen and genitalia are stored in glycerin in a glass vial mounted on the same pin. Adult specimens in the Specimens examined sections indicated as "[molecular voucher]" are only the abdomen, head, wings and some legs (and puparium in some cases) in a glycerin vial mounted on a pin and deposited in the CSCA; the thorax of each was used in the molecular portions of this and other ongoing work. These specimens, along with other specimens being preserved for molecular work, are indicated with a unique "specimen \#", which correspond to an entry in the CSCA-FTC database. Some complete specimens in the CSCA-FTC are indicated with a unique "specimen \#", or for series in the same vial with a "voucher \#", which correspond to samples in the freezer and database, whether or not used in these analyses. Note, some pinned specimens in CSCA also have a "specimen \#", indicating their data being recorded in the CSCA-FTC database. Larval and puparial specimens indicated as "[molecular voucher]" are slide mounted in Canada balsam after non-destructive DNA extraction. Molecular vouchers with specimen numbers beginning with "ENT" are held in YPM. 


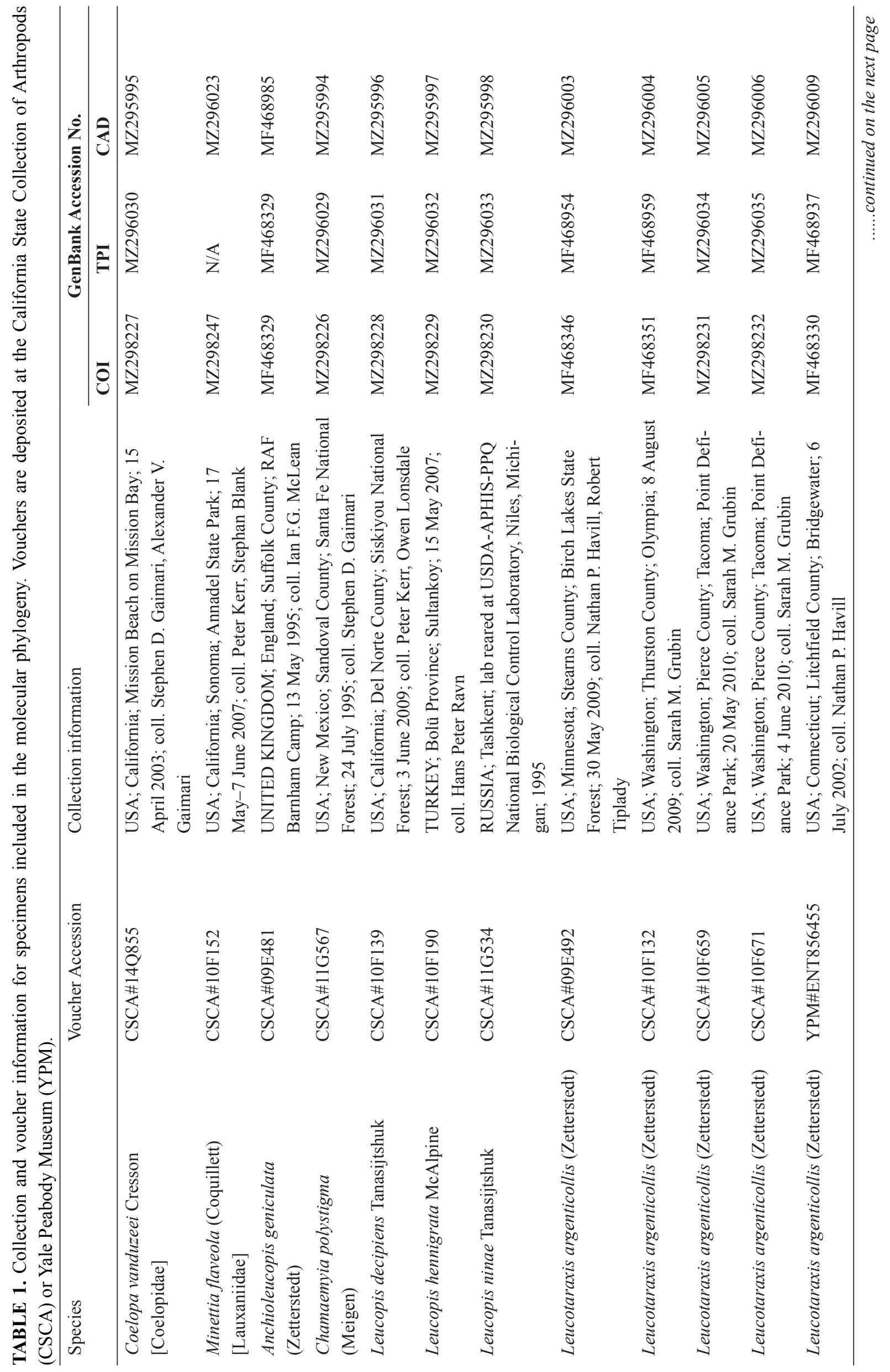




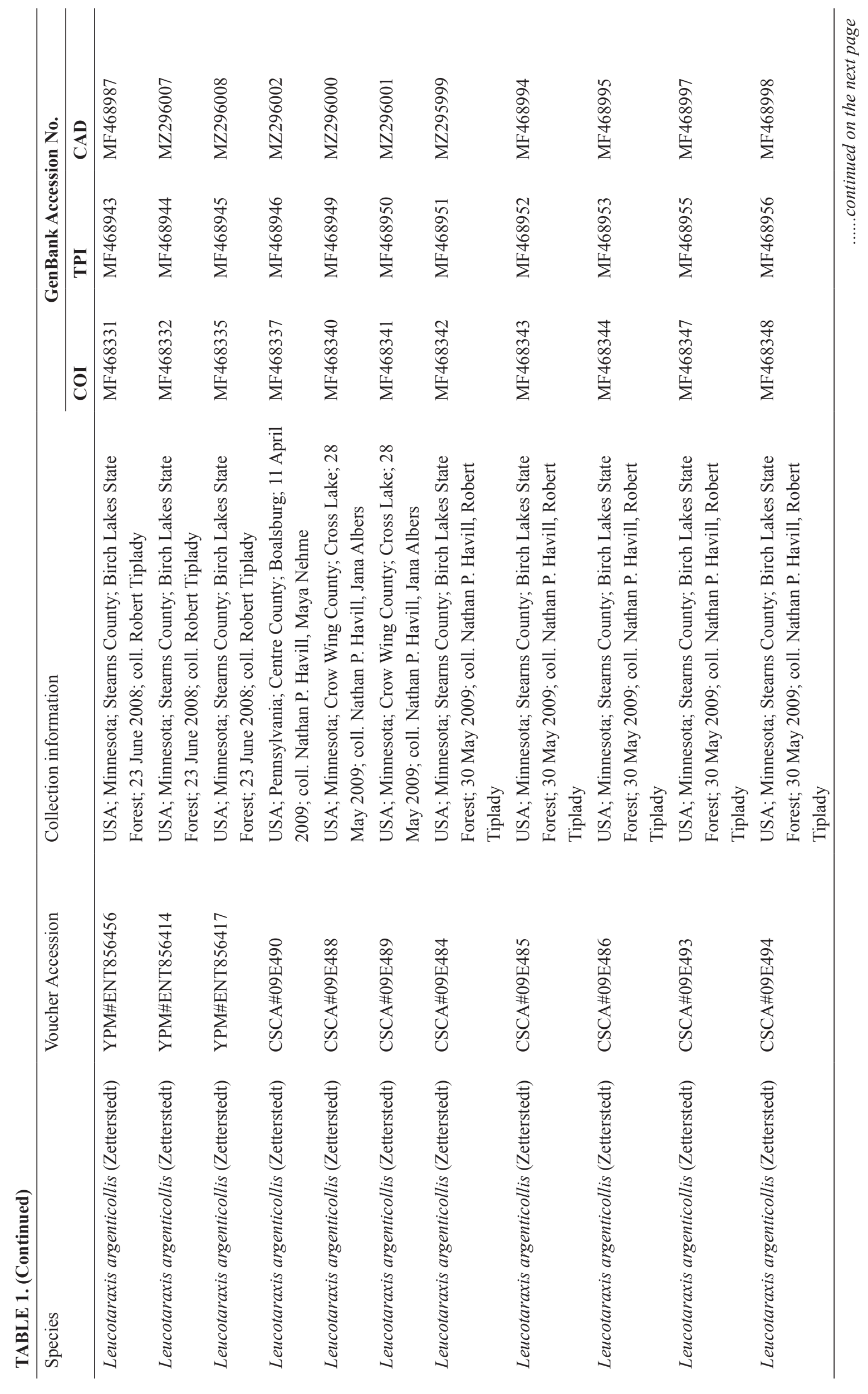




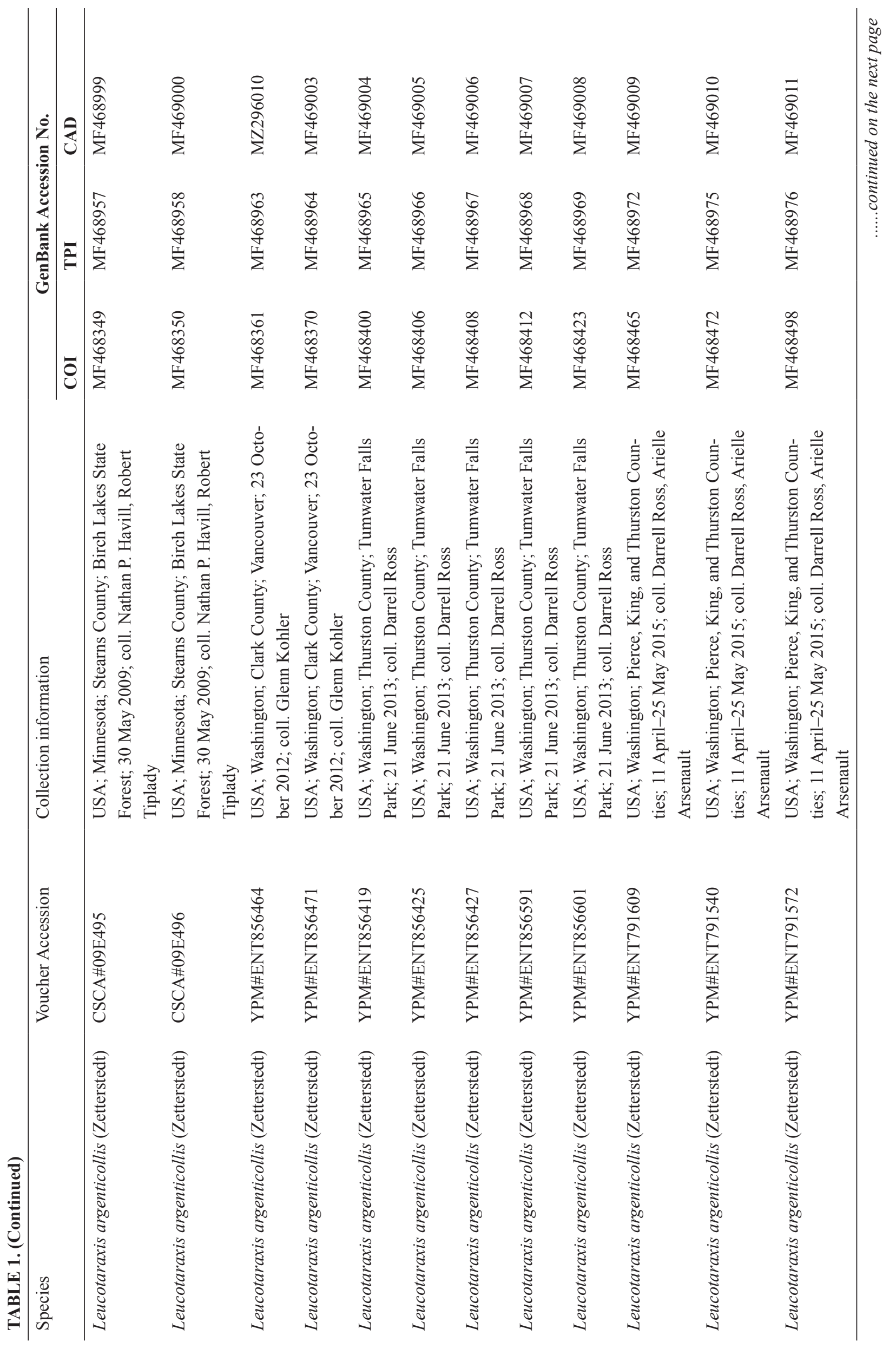




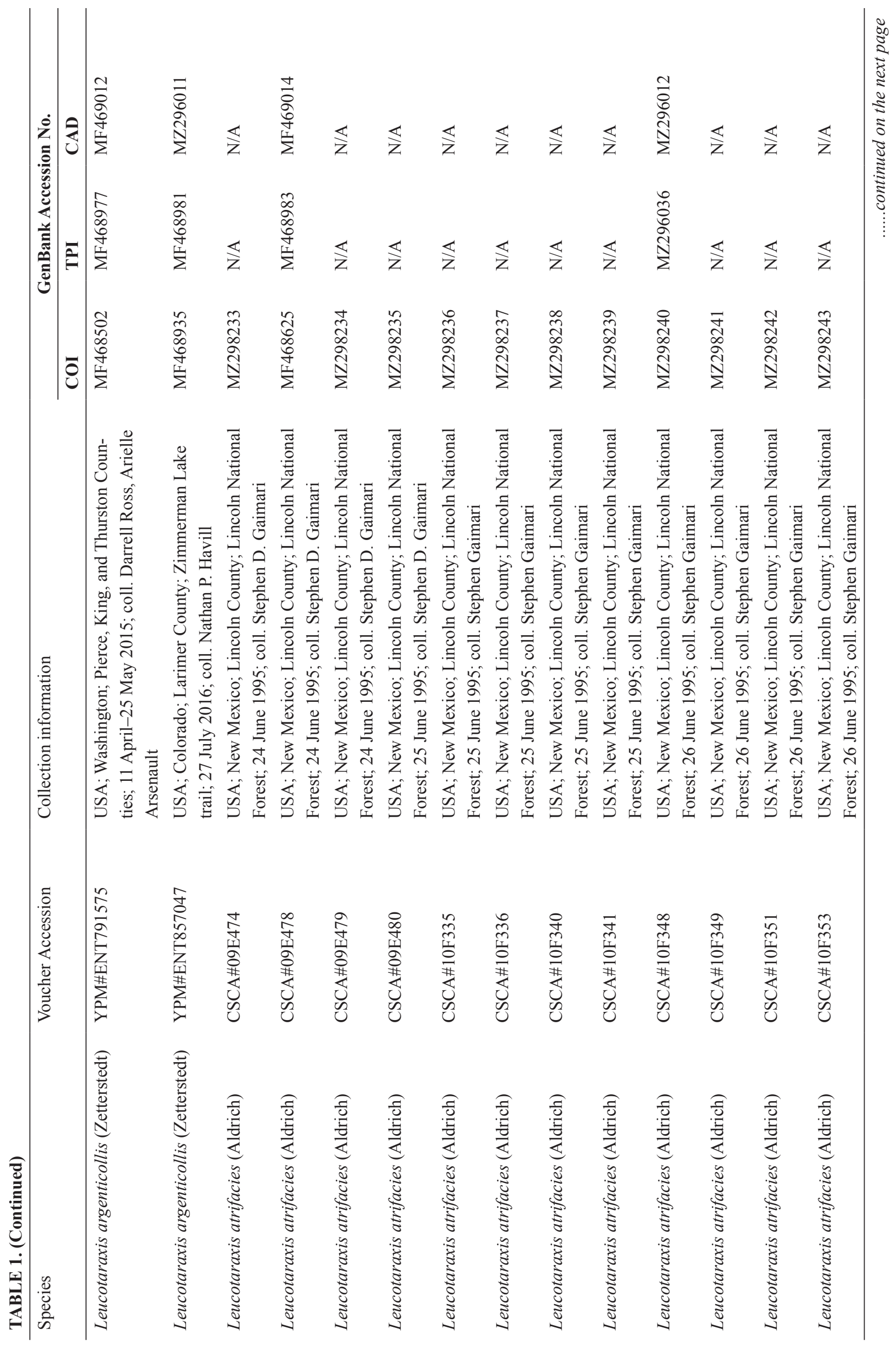




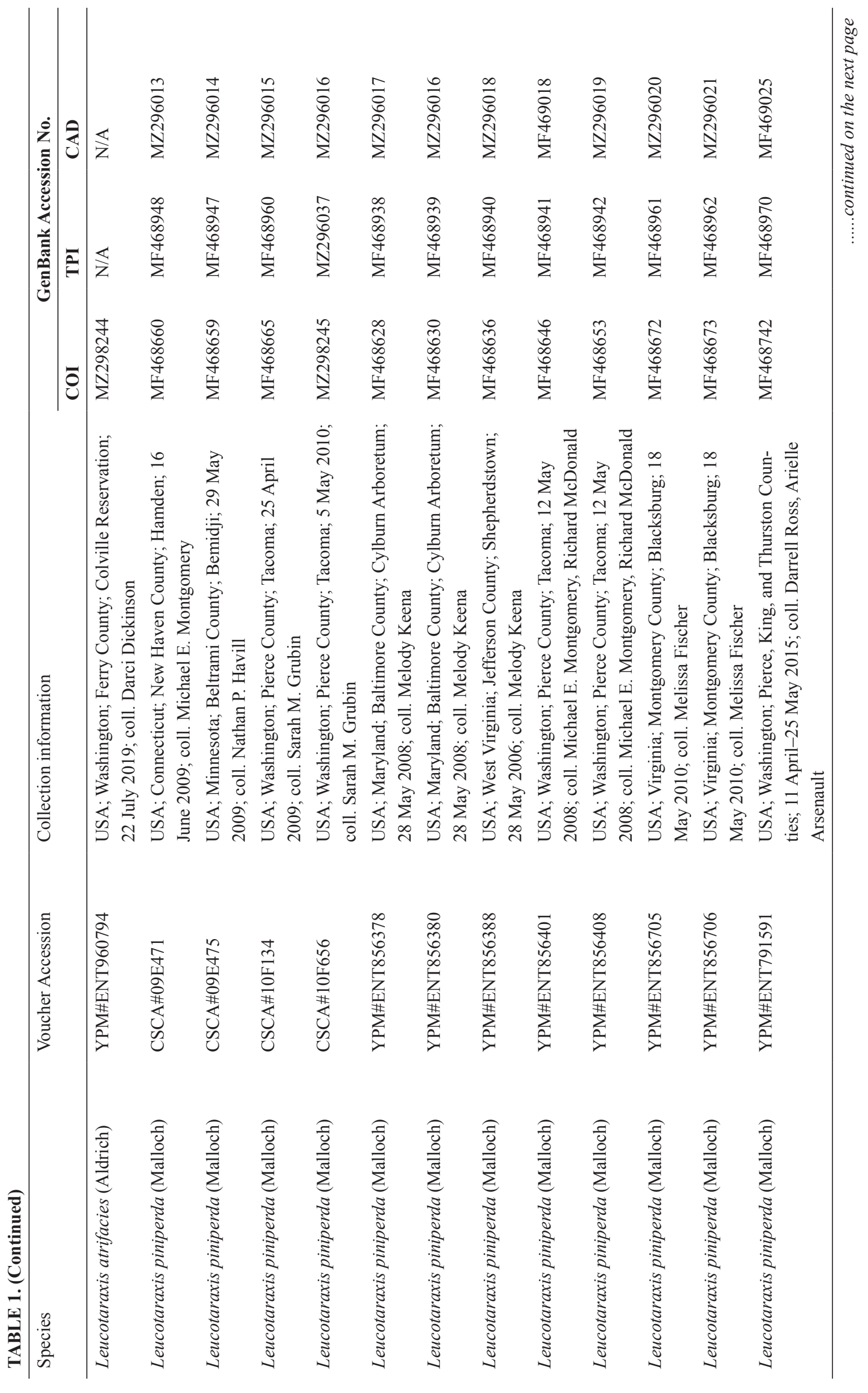




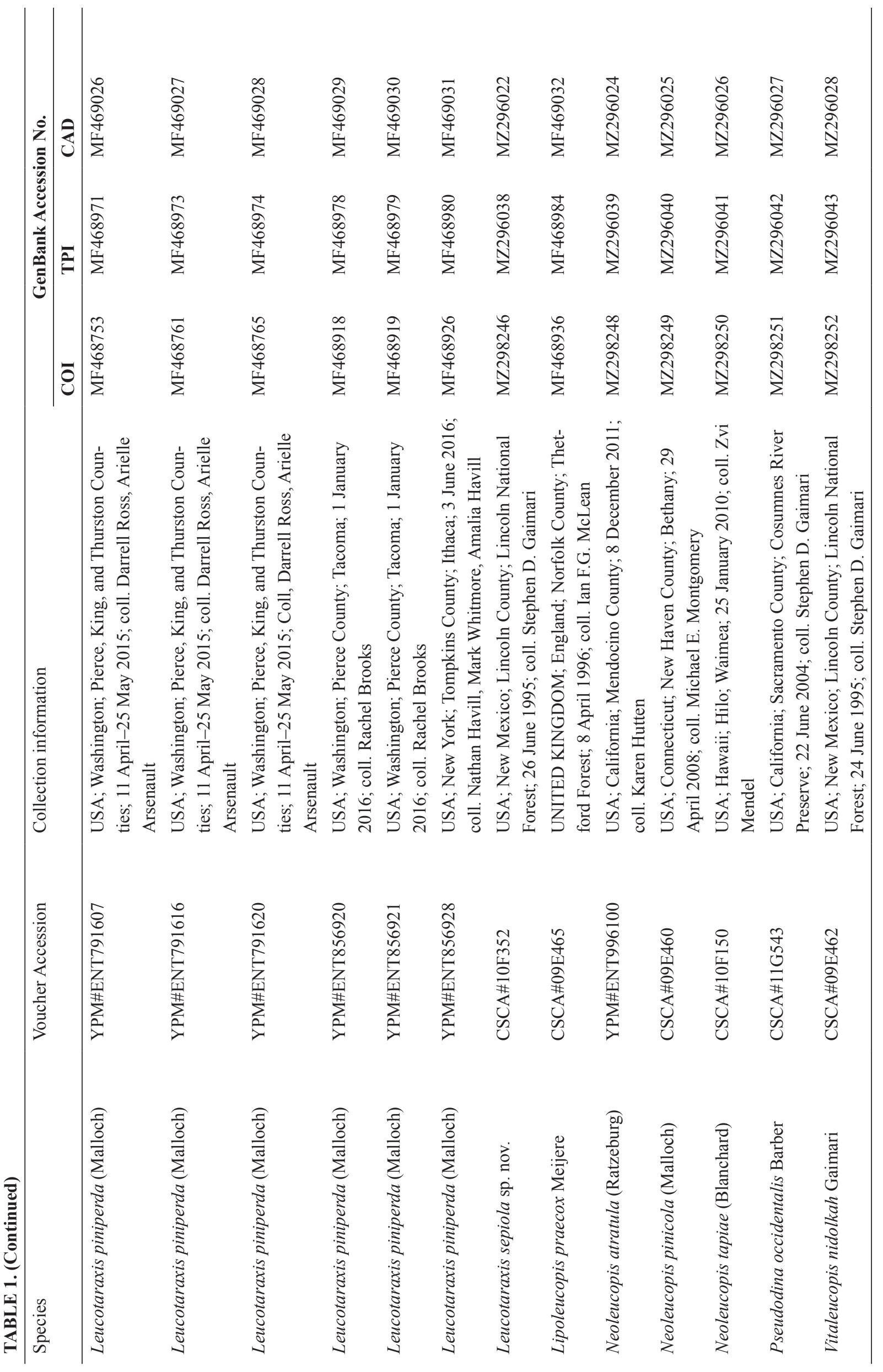


Terminology. Basic terminology follows Cumming \& Wood (2009) and Gaimari (2010). Body length was measured in lateral view by adding the length of the head (without antennae) through the thorax with the abdominal length, to account for differential curling of the abdomens. For head ratios: the head length and height were measured from a lateral view, respectively, from the lunule through the posterior occiput, and from the dorsal edge of the head through the ventral edge of the gena; the frons width and length were measured from an anterodorsal view, with the frons width through the anterior ocellus, and the frons length from the anterior ocellus through the anterior edge of the frons. On the thorax, the scutal width is measured at the level of the supra-alar setae, and the scutellar width is measured through the area of contact with the scutum. Wing width was measured at the widest level just proximal to the apex of $\mathrm{CuA}_{1}$. All other measurements were made through their maximum values.

All chamaemyiid taxa in the Annotated list of species of Chamaemyiidae feeding on Pinaceae-infesting Sternorrhyncha section appear with full authority and date information, current and original genus combinations, type information, and notes on distribution and biology. As such, the date is not given for those genus and species names in the text.

Molecular phylogeny. The phylogeny of Leucotaraxis with other representatives of Chamaemyiidae and two nonchamaemyiid outgroup taxa was elucidated using sequence data from one mitochondrial and two nuclear genes. For adult flies, DNA was extracted from the ground-up thorax. For larval flies, DNA was extracted non-destructively by cutting a small slit in the specimen with a scalpel and retaining the cuticle after proteinase $\mathrm{K}$ digestion. In both cases, extraction was performed using DNA IQ Extraction Kit (Promega). The 5' end of the mitochondrial cytochrome c oxidase subunit I gene (COI) was amplified using the primers LepF1 and LepR1 (Hebert et al. 2004). A portion of the nuclear triose phosphate isomerase (TPI) gene was amplified using primer 111Fb (Bertone et al. 2008), and Cham275R (GCCCAGACGGGCTYGTAGGC) modified from 275R (Bertone et al. 2008). A portion of the nuclear carbamoylphosphate synthetase domain of the CAD (rudimentary) gene was amplified in two overlapping fragments using the primers $787 \mathrm{~F}$ and Cham1098R, and 1057F and 1278R. Primers were designed by Moulton \& Wiegmann (2004) with the exception of Cham1098R (TTAGGTAGCTGCCCTCCCAT), which was modified from their primer 1098R. Sequencing reactions were performed using the BigDye Terminator kit (Applied Biosystems, Foster City, California) and analyzed on an Applied Biosystems 3730 automated sequencer at the DNA Analysis Facility on Science Hill at Yale University, New Haven, Connecticut. Sequences from each gene were aligned using MUSCLE 3.6 (Edgar 2004). Maximum likelihood analysis was performed using the concatenated sequence data using IQTREE v.2.1.3 (Nguyen et al. 2015). Node support was generated with 1,000 UFBoot replicates. Coelopa vanduzeei Cresson (Coelopidae) and Minettia flaveola (Coquillett) (Lauxaniidae) were included as outgroup taxa, the latter being a fellow member of the Lauxanioidea, and the former a member of the related superfamily Sciomyzoidea. Many of the Leucotaraxis sequences were reported previously in Havill et al. (2018). All new sequences generated for this study were deposited in GenBank, and collection and voucher data for included specimens are shown in Table 1.

\section{Leucotaraxis gen. nov.}

urn:lsid:zoobank.org:act:C920C4F9-D987-4926-B4FB-C5BB4DC5E7B4

"Undescribed Genus C" - Gaimari, 2010: 1005.

Type species. Leucopis atrifacies Aldrich, by present designation.

Etymology. The prefix Leuco-, in reference to the genus Leucopis, appended with the feminine Greek noun taraxis, meaning "confusion, disturbance." The name refers to the historical confusion surrounding the proper genus placement of the included species.

Diagnosis. The body is compact and small (2.1 mm or less), but more delicate than typical leucopines. Postocellar and ocellar setae are absent. The frons is flat and meets the lunule at nearly a $90^{\circ}$ angle. The fronto-orbital and median areas of the frons have long, erect white setulae, but lack setae. The lunule has a straight to slightly curved upper margin, appearing squared, and in some species is dark brown to black along with the face, parafacial and medial part of the gena. The face has deep antennal grooves and is either all black or all silvery pruinose. The mouthparts are very small and held within the oral cavity above the small cylindrical palpi. The antennae are black. The scutum is entirely silvery-grey pruinose, lacking dorsocentral vittae, and with 2 pairs of dorsocentral setae in 
the posterior part of the scutum. Prescutellar setae are absent. Prescutellum present. Scutellum concolorous with scutum. The abdominal tergites are dark silvery-grey pruinose, except the dorsal parts of syntergite $1+2$ and tergite 3 are bronzy pruinose. In the male genitalia, the phallus is always elongated, and can be either gently or strongly curved, and some species lack a pregonite. In the female, sternite 6 is wider than preceding sternites, tergite 7 is strap-like when present, sternite 7 is arcuate when present, all setulae of the pseudo-ovipositor are tiny, and spermathecae are $2+2$.

Immatures. The eggs and puparia are known for three of the species included in this genus, with the following generalities in common. Egg (Fig. 1A). With series of 11-13 longitudinal ridges frequently anastomosing into a diagonally reticulated pattern, most densely at posterior pole. Puparium (Fig. 1B). The puparium is barrel-shaped, slightly flattened, with a convex dorsal surface which is smooth except for tiny spicules. The dehiscent anterior segments (dorsal and ventral) each slope in lateral view into a thin anterior-most part. Anterior spiracle with slit-like spiracular opening at tip of each of 3-5 finger-like lobes. The posterior spiracles are on separated, raised tubercles with sharp strong spinules in the distal half (Figs 1C-D); distally, spiracle trilobed, with slit-like spiracular opening at tip of each finger-like lobe.

Biology. Species of this genus are known as larval predators of Adelgidae on Pinaceae, with three species also associated with aphids in the genus Cinara Curtis. Although never reared from Cinara as prey, adults have been collected from Cinara-infested pines.

Remarks. Contrary to Tanasijtshuk (1986) placing Leucopis adelgivora Tanasijtshuk in his "argenticollisgroup" with an implied close relationship, that species is a typical Leucopis (Leucopis) that happens to feed on adelgids and does not belong to this new genus. In describing Leucopis astonea McAlpine, McAlpine (1977) posited its relationship with the group of species now included in this genus. However, despite several characteristics held in common, it is included in the discrete genus Vitaleucopis, which differs in several substantial respects from Leucotaraxis, including egg and puparial morphology, as well as adult external and genitalic morphology. However, it does seem possible that both genera belong to a complex of related genera with similar feeding habits, also including Anchioleucopis Tanasijtshuk, Lipoleucopis Meijere and Neoleucopis Malloch. The key to species of Leucotaraxis is included as couplets 38-43 in the key to chamaemyiid species associated with Pinaceae-infesting Sternorrhyncha, below.

Leucotaraxis argenticollis (Zetterstedt), comb. nov.

(Figs 1B-C, 2A-B, 3A, 3D-E)

Leucopis argenticollis Zetterstedt 1848: 2714. Sweden. Gottlandia (LT Õ, MZLU). References - Czerny $1936: 10$ (key), 11 (redescription); McAlpine \& Tanasijtshuk 1972: 1865 (redescription), 1870 (lectotype designation), fig. 1 (head), fig. 3 (abdomen), figs 5-6 (female terminalia), figs 8-16, 19 (male genitalia), figs 20-27 (immatures); Tanasijtshuk 1986: 201 (redescription), figs 333-337 (male genitalia), figs 338-345 (larval); Papp 1979: 82 (key, description), fig. 54A (abdomen), fig. 54B (male genitalia); Kohler et al. 2008: 494 (biology); Grubin et al. 2011: 1410 (biology); Havill et al. 2018 (biology, population genetics); Neidermeier et al. 2020 (biology, biological control); Dietschler et al. 2021 (biology, biological control).

Leucopis orbitalis Malloch 1921: 352. United States. Illinois: Dundee (HT ô, INHS). References - McAlpine $1965: 709$ (catalog); McAlpine \& Tanasijtshuk 1972: 1865 (synonymy).

Leucopis sp. nr. orbitalis. References - Rao 1965: 43; McAlpine \& Tanasijtshuk 1972: 1865 (identity).

Diagnosis. The face and lunule (Fig. 2B) are silvery-grey pruinose. The postpronotum (Fig. 2A) has 1 to several long setulae (longer than the setulae on the scutum) medially from the postpronotal seta. In the male (see figs 8-16, 19 in McAlpine \& Tanasijtshuk 1972), the epandrial complex is simple, small, and yellowish- to silvery-grey pruinose, with no central epandrial process; the surstylar lobe is short and slender, the phallus (Fig. 3A) is broad in lateral view with a wedge-shaped anterobasal process at a $90^{\circ}$ angle from the thin elongate pointed process. In the female (Figs 3D-E), tergites (Fig. 3E) with tergite 6 enlarged and slightly less than $2 \mathrm{X}$ wider than long, tergite 7 present and strap-like, tergite 8 longer than wide, slightly tapering distally; sternites (Fig. 3D) with sternite 6 enlarged and about $2 \mathrm{X}$ wider than long, sternite 7 present and arcuate.

Immatures. Egg. Measurements as in Leucotaraxis atrifacies (Fig. 1A). Larvae. Described and figured in McAlpine \& Tanasijtshuk (1972). Puparium (Fig. 1B). Length 2.3-2.8 mm, width 0.9-1.0 mm. Dehiscent anterior segments (dorsal and ventral) $0.05-0.06 \mathrm{~mm}$ long. Raised posterior spiracular tubercles (Fig. 1C) $0.12-0.16 \mathrm{~mm}$ long, darkly sclerotized. 
Biology. Predators as larvae on species of Adelges Vallot and Pineus Shimer (Hemiptera: Adelgidae) on Pinaceae (Abies, Picea, Pinus, Tsuga). Specific records (including our own rearings) include: Adelges piceae on Abies balsamea; Adelges tsugae on western hemlock, Tsuga heterophylla (Kohler et al. 2008); Pineus abietinus Underwood \& Balch on Abies lasiocarpa; Pineus boerneri on Pinus henryi; Pineus coloradensis (Gillette) on Pinus banksiana, Pinus contorta, Pinus flexis, Pinus monticola, and Picea engelmannii; Pineus pineoides (Cholodkovsky) on Picea sp.; Pineus pini on Pinus sylvestris; Pineus similis (Gillette) on Picea glanca and Picea abies; Pineus strobi on Pinus strobus (Wantuch et al. 2019); Pineus spp. on Picea glauca, Pinus contorta, Pinus insularis, Pinus pentaphylla, Pinus resinosa, Pinus strobus and Pinus sylvestris (McAlpine \& Tanasijtshuk 1972).

Several specimens were swept from infestations of Cinara ponderosae (Williams) in young stands of Pinus ponderosa (e.g., height less than $5 \mathrm{~m}$ throughout the large stand), but despite rearing $>150$ chamaemyiid larvae from this host, none were this species but were instead Vitaleucopis nidolkah Gaimari and an undescribed species of Leucopis (Leucopis). It remains a possibility that Leucotaraxis argenticollis is also a predator in that system, whether on the Cinara aphids or on adelgids unseen by the first author while collecting.
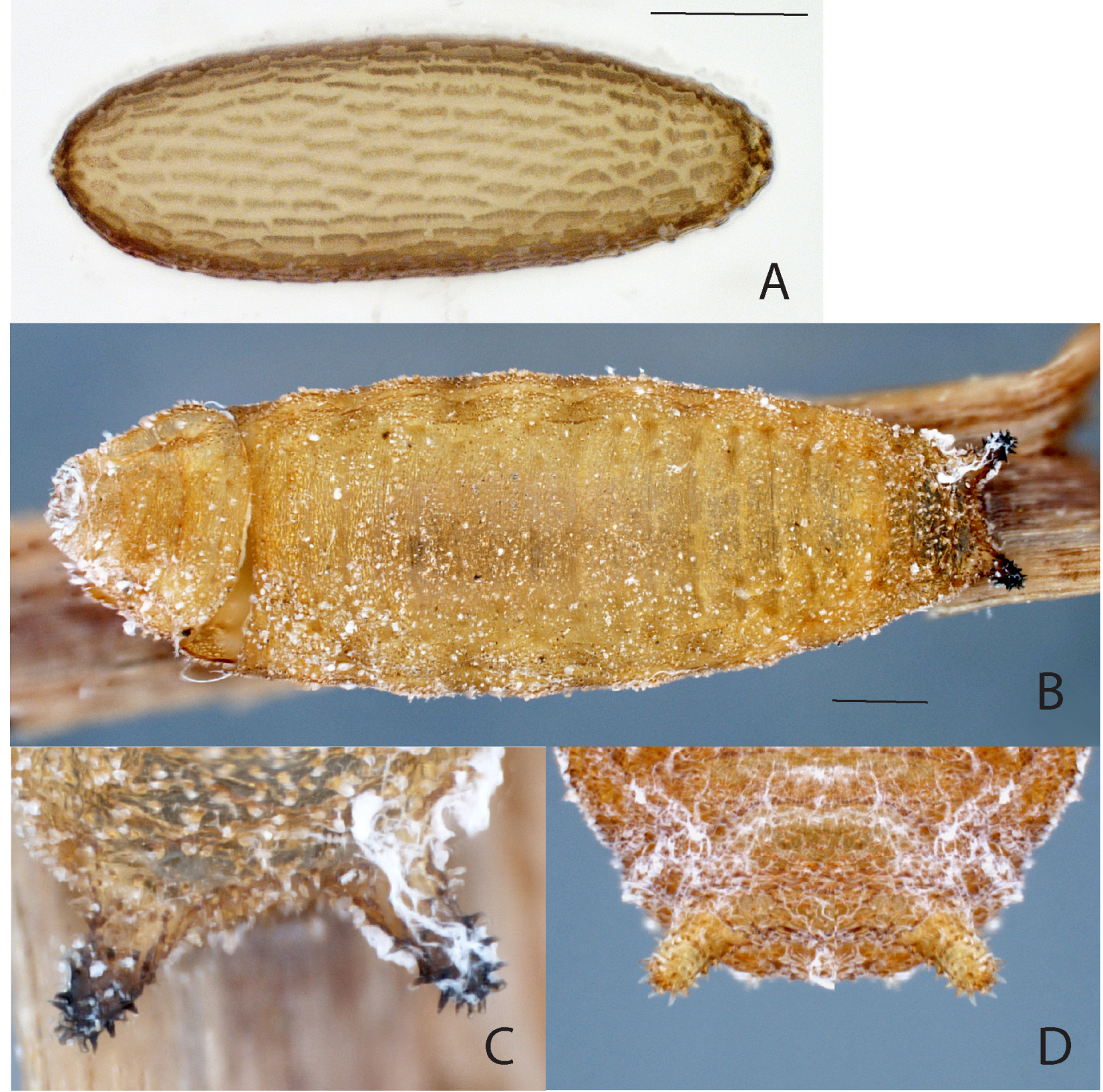

FIGURE 1. Immature stages of Leucotaraxis species. A. L. atrifacies, egg, dorsal view, posterior pole right (measure bar $=0.1$ $\mathrm{mm}$ ). B-C. L. argenticollis, puparium, dorsal view: B. habitus (measure bar =0.2 mm); C. posterior spiracles. D. L. piniperda, puparial posterior spiracles, dorsal view. 

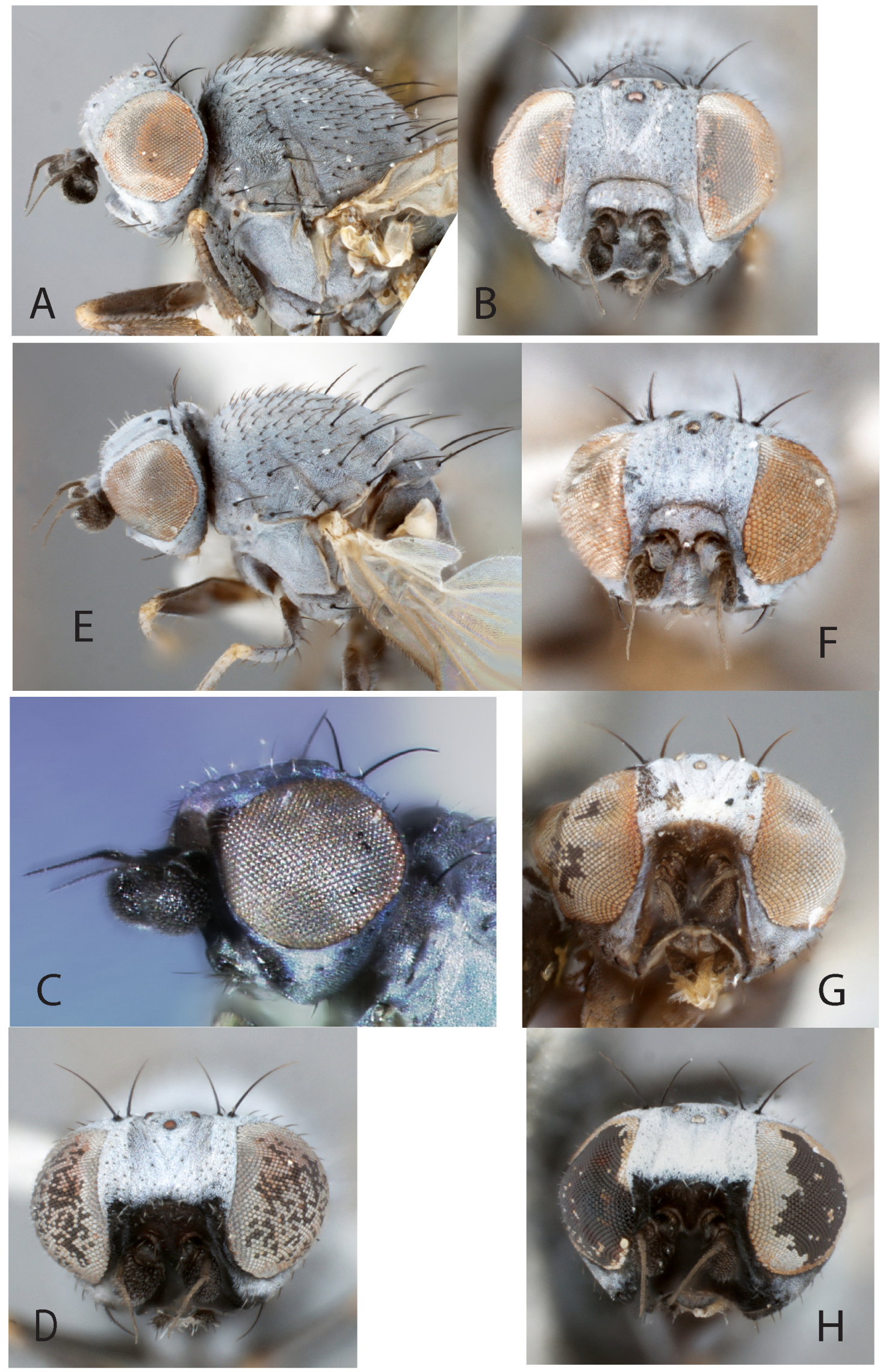

FIGURE 2. Leucotaraxis species. A-B. L. argenticollis: A. head and thorax, lateral view; B. head, anterior view. C-D. L. atrifacies: C. head and anterior thorax, lateral view; D. head, anterior view. E-H. L. piniperda: E. head and thorax, lateral view; F-H. heads, anterior view: F. eastern form; G. mixed form; H. western form. 

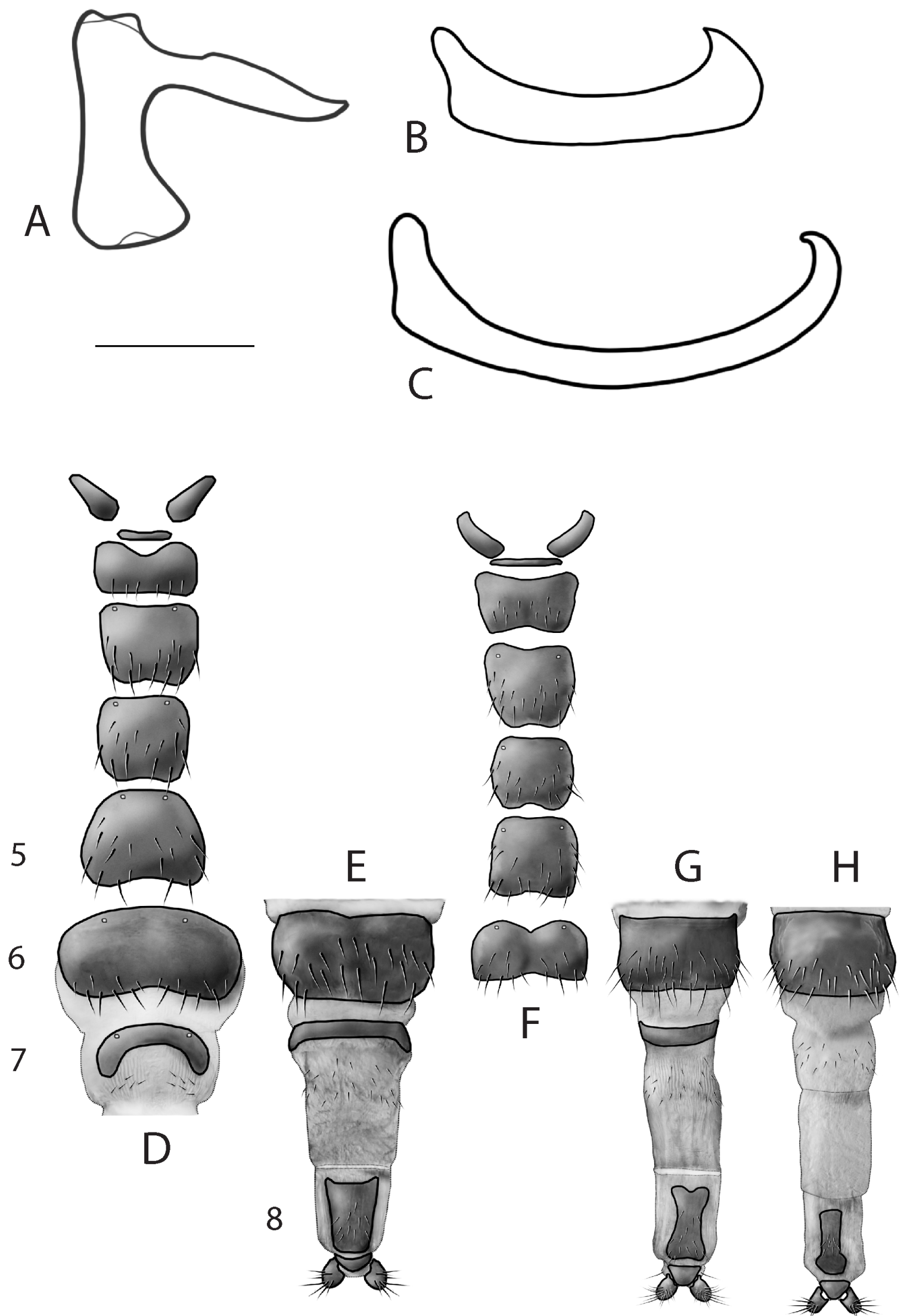

FIGURE 3. Terminalia of Leucotaraxis species. A-C. Male, phallus, oriented with distal part right (measure bar $=0.1 \mathrm{~mm})$ : A. L. argenticollis; B. L. atrifacies; C. L. piniperda. D-H. Female, terminalia. D-E. L. argenticollis: D. ventral view; E. dorsal view. F-G. L. atrifacies: F. ventral view; G. dorsal view. H. L. piniperda, dorsal view. Numbers to the left indicate segments (D, F are sternites; E, G, H are tergites). 
Remarks. At two different localities (one in New Mexico and one in Arizona), this species was collected together with Chamaethrix necopina Gaimari, Leucotaraxis atrifacies and Vitaleucopis nidolkah, and at the New Mexico locality also with Leucotaraxis sepiola. The puparial stage is distinguishable from that of Leucotaraxis atrifacies and L. piniperda by the slightly longer posterior spiracular tubercle, which is more darkly sclerotized distally in this species, and the slightly larger size. The three specimens from Coconino County, Arizona, were mistakenly listed by Tanasijtshuk (2002) as Leucopis piniperda.

Distribution. Nearctic: Canada (Alberta, British Columbia, Manitoba, Newfoundland, New Brunswick, Northwest Territories, Ontario, Quebec). USA (Alaska, Arizona, California, Colorado, Connecticut, Georgia, Idaho, Illinois, Massachusetts, Minnesota, Montana, New Hampshire, New Mexico, New York, North Carolina, Ohio, Oregon, Pennsylvania, Utah, Virginia, Washington, Wyoming). Oriental. India (Rao 1965). Palearctic: England (McLean 1982), Japan, Russia (McAlpine \& Tanasijtshuk 1972), Sweden.

Specimens examined. Nearly all specimens from McAlpine \& Tanasijtshuk (1972) were examined, with additional specimens as follows. CANADA: ALBERTA. Seele, $\mathrm{H}_{2} \mathrm{O}$ Rd, 12.i.1971, coll. L.S. Skaley, ex. duff around $P[$ inus]. contorta, 3916, 74-726 15 (1 9 , CNC). BRITISH COLUMBIA. Atlin, 2200 ft., 2.vi.1955, coll. H. Huckel (1 9 , CNC). Burns Lake, 8.vii.1993, coll. L.M. Humble, ex. Pinus contorta foliage, emerged 20.vii.1993, FIDS No. 93-0504-02 (1 q, PFCA). Kitimat, 2.vi.1960, coll. R. Pilfrey (1 ô, CNC), coll. J.G. Chillcott, ex. hemlock forest (1 q, CNC). Princeton, 19.v.1986, ex. pine leader (1 $\circ$, CNC). Saanichton, 26.iii.1993, coll. L.M. Humble, ex. beating of hemlock foliage infested with Adelges tsugae, FIDS No. 93-0005-01 (1 ô, 1 \%, CSCA; 1 o, 2 q, PFCA), 30.iv.1993, FIDS No. 93-0037-02 (2 ô, 2 ㅇ, PFCA), 11.vi.1993, FIDS No. 93-0204-01 (1 $\circ$, PFCA), 28.v.1993, ex. puparia in Adelges tsugae wool on Tsuga heterophylla, emerged 31.v.1993, FIDS No. 03-0102-01 (1 ô, 1 ㅇ, CSCA; 1 ô, 1 †, PFCA). Summit Lake, Mile 392 Alaska Highway, 4200 ft., 21.vii.1959, R.E. Leech (1 ô, 2 , CNC), 5000 ft., 6.vii.1959, coll. R.E. Leech (1 đ, CNC). ONTARIO. Ottawa, 4.vii.1963, coll. J.R. Vockeroth, ex. Pineus similis on Picea glauca, emerged 15.vii.1963 (1 \& with puparium, CNC). Ottawa, 17.vii.1963, coll. J.R.

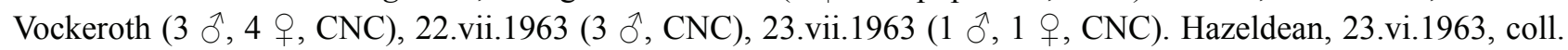
A.W. Steffan, ex. reared on Pineus similis on Picea abies, emerged 7.vii.1963 (1 9 , CNC). QUEBEC. Duchesnay, 21.vii.1942, coll. Jos. I. Beaulne (1 ठ, QMOR). Gatineau County, Masham Township, 21.v.1974, coll. D.M. Wood (1 9, CNC). USA: ALASKA. Matanuska-Susitna Borough, Big Lake, 10.vii.2020, coll. Jason Moan, ex. Pineus coloradensis on Pinus contorta (1 larva [molecular voucher], YPM; ENT996080). ARIZONA. Apache Co., Apache National Forest, 0.3 mi. S mi. 249 on US Route 191, 5 mi. S Alpine, along Coleman Creek, 33॰47’24”'N 109 $10^{\circ}$ '01”'W, 2500 m, 30.vi.1995, coll. S.D. Gaimari, ex. sweep Pinus ponderosa (2 9 , CSCA), 1.vii.1996 (1 + , CSCA); clearing 6.4 mi. N southern junction Forest Roads 24 \& 25 on Road 24, 33³9'22”N 109²1’38”W, 2725 m, 2.vii.1995, coll. S.D. Gaimari, ex. sweep vegetation, including Pinus ponderosa (2 q, CSCA). Coconino Co., Fort Valley Experiment Station, 13.iii.1929, Lot VII (1 ㅇ, USNM), 15.iii.1929, Lot VI (1 §̂, USNM), 18.iii.1929, Lot II (1 + , USNM). CALIFORNIA. Riverside Co., Riverside, UCR campus, 10.vi.1963, coll. R.C. Dickson (1 q, CNC). COLORADO. Larimer Co., Zimmerman Lake trail, 40.5397,-105.8792, 27.vii.2016, coll. Nathan Havill, ex. Pineus coloradensis on Picea engelmannii (1 larva [molecular voucher], YPM; ENT857047). CONNECTICUT. Hartford Co., Hartford, Cedar Hill Cemetery, 41.7266, -72.6932, 5.vi.2016, coll. M.E. Montgomery, ex. Pineus strobi on Pinus strobus (6 larvae [molecular voucher], YPM; ENT961206-11). Litchfield Co., Bridgewater, Skyline Ridge Rd., 41.4704, -73.3190, 6.vii.2002, coll. N. Havill, ex. Pineus strobi on Pinus strobus (1 puparium [molecular voucher], YPM; ENT856455). GEORGIA. Union Co., Byron H. Reese Trailhead, 34.7422, -83.9227, 20.v.2018, coll. Jim Sullivan, ex. Pineus strobi on Pinus strobus (7 larvae [molecular voucher], YPM; ENT996058-64). White Co., Helen, Chattahoochee National Forest, 34.7930,-83.7558, 13.ix.2019, coll. Jim Sullivan, ex. Pineus strobi on Pinus strobus (7 larvae [molecular voucher], YPM; ENT979185-88, ENT979191, ENT979199, ENT979204). IDAHO. Boise Co., Boise National Forest, 43.8963, -115.7125, 13.ix.2016, coll. Kelsey Bedford, ex. Adelges piceae on Abies lasiocarpa (1 larva [molecular voucher], YPM; ENT961177). Kootenai Co., Coeur d'Alene, 47.697, -116.772, 23.v.2013, coll. Gina Davis, ex. Adelges tsugae on Tsuga heterophylla (5 larvae [molecular voucher], YPM; ENT856473-77). MASSACHUSETTS. Franklin Co., Sunderland, Mt. Toby State Forest, 42.4892, -72.5314, 13.v.2018, coll. Ryan Crandall, ex. Pineus strobi on Pinus strobus (4 larvae [molecular voucher], YPM; ENT99606770). Worcester Co., Worcester, 42.2790, -71.7733, 12.v.2018, coll. Felicia Andre, ex. Pineus strobi on Pinus strobus (1 puparium, 3 larvae [molecular voucher], YPM; ENT996065-67). MINNESOTA. Crow Wing Co., Kettleson's, $46.65631^{\circ} \mathrm{N} 94.06856^{\circ} \mathrm{W}, 28 . v .2009$, coll. N. Havill \& J. Albers, ex. reared from Pineus strobi on Pinus strobus, N. Havill sample 09-135, Specimen \#09E489 (1 ठ̊ [molecular voucher], CSCA), Specimen \#09E488 (1 $\widehat{\partial}$ [molecular 
voucher], CSCA), Specimen \#09E504 (1 ð [molecular voucher], CSCA), Specimen \#09E525 (1 ㅇ, CSCA-FTC). Itasca Co., Grand Rapids, UMN North Central Research and Outreach Center, 47.2517, -93.5103, 28.v.2009, coll. Nathan Havill, Jana Albers, ex. Pineus strobi on Pinus strobus (1 larva [molecular voucher], YPM; ENT856650).

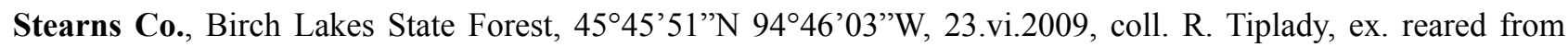
Pineus strobi on Pinus strobus (1 puparium, 2 adults [molecular voucher], YPM; ENT856456 (puparium), ENT856414, ENT856417), 30.v.2009, coll. N. Havill \& R. Tiplady, ex. reared from Pineus strobi on Pinus strobus,

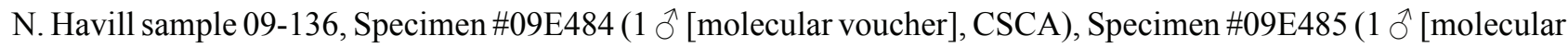
voucher], CSCA), Specimen \#09E486 (1 §̂ [molecular voucher], CSCA), Specimen \#09E487 (1 $\hat{\sigma}$ [molecular

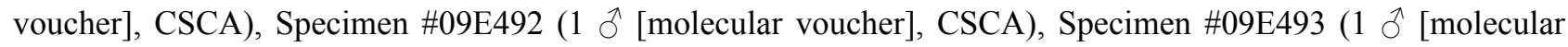
voucher], CSCA), Specimen \#09E494 (1 §̊ [molecular voucher], CSCA), Specimen \#09E495 (1 $\hat{\sigma}$ [molecular voucher], CSCA), Specimen \#09E496 (1 ð̊ [molecular voucher], CSCA), Specimen \#09E497 (1 ð [molecular

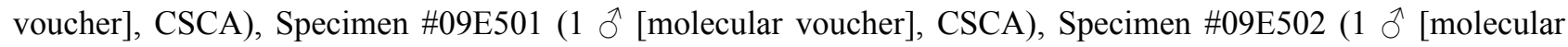
voucher], CSCA), Voucher \#09E509 (13 \&, CSCA-FTC). MONTANA. Park Co., Yellowstone National Park, Cascade Lake Trail, 44.7518,-110.4863, 19.ix.2016, coll. Gina Davis, Lee Pederson, ex. Pineus coloradensis on Pinus contorta (1 larva [molecular voucher], YPM; ENT96215). Teton Co., Choteau 47.8976, -112.5721, 24.viii.2017, coll. Gina Davis, ex. Pineus coloradensis on Pinus flexilis (2 larvae [molecular voucher], YPM; ENT996081-82). NEW HAMPSHIRE. Hillsborough Co., Hillsboro, Fox State Forest, 43.1316, -71.9286, 29.viii.2016, coll. Jennifer Weimer, ex. Pineus strobi on Pinus strobus (3 larvae [molecular voucher], YPM; ENT961212-14). Rockingham Co., Pawtuckaway State Park, 43.0869,-71.1574, 30.iv.2019, coll. Jennifer Weimer, ex. Pineus strobi on Pinus strobus (1 larva [molecular voucher], YPM; ENT961221). NEW MEXICO. Lincoln Co., Lincoln National Forest, 2.4 km W Angus, Mills Canyon, along Rio Bonito, 3327’05”N 10541’46”'W, 2130 m, 18-19.vi.1995, coll. S.D. Gaimari, ex. sweep colonies of Cinara ponderosae on Pinus ponderosa (1 J, CSCA), 26.vi.1995 (3 \&, CSCA-FTC). McKinley Co., Cibola National Forest, Zuni Mountains, 4.4 mi. SE Fort Wingate,

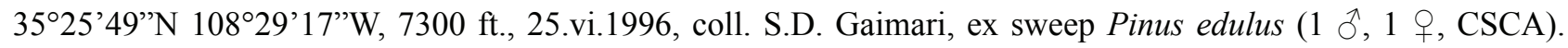
NEW YORK. Monroe Co., Rochester, Highland Park, 43.1278, -77.6122, 8.vii.2017, coll. Cynthia Smith, ex. Pineus strobi on Pinus strobus (1 puparium [molecular voucher], CUIC). OHIO. Portage Co., Kent, 13.vii.1969, coll. T.P. Sluss ( 1 J, UAIC). OREGON. Deschutes Co., Deschutes River, $1 \mathrm{mi}$. SW Pringle Falls, 4250 ft., 31.vii.1970, coll. Paul H. Arnaud, Jr., ex. flight trap (1 + , CAS). Lake Co., Fort Rock, Deschutes National Forest, 43.5651, -121.1768, 25.iv.2104, coll. Glenn Kohler, ex. Pineus coloradensis on Pinus contorta (1 puparium [molecular voucher], YPM; ENT996083). PENNSYLVANIA. Centre Co., Boalsburg, Shingletown Rd. \& West

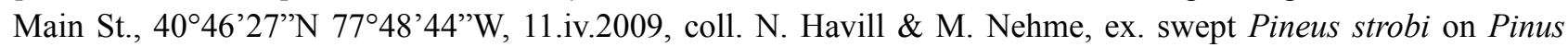

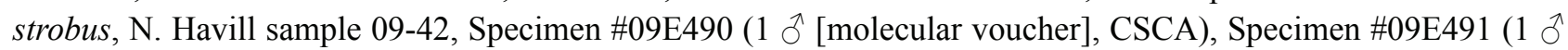
[molecular voucher], CSCA). UTAH. Weber County, Eden, 41.3715, -111.9228, iv.2020, coll. Justin Williams, ex. Adelges piceae on Abies lasiocarpa (1 larva [molecular voucher], YPM; ENT996084). VIRGINIA. Giles Co., Jefferson National Forest, Dismal Falls, 37.19263,-80.8923, 13.iv.2016, coll. Holly Wantuch, ex. Pineus strobi on Pinus strobus (6 larvae [molecular voucher], YPM; ENT906890, ENT906894-95, ENT906897, ENT906899-900). Pulaski Co., Pulaski, Gatewood Park and Reservoir, 37.0622,-80.8363, 2.vii.2014, coll. Holly Wantuch, ex. Pineus strobi on Pinus strobus (1 larva [molecular voucher], YPM; ENT906874). Wythe Co., Speedwell, Mt. Rogers National Recreation Area, 36.7722, -81.1752, 23.vi.2014, coll. Holly Wantuch, ex. Pineus strobi on Pinus strobus

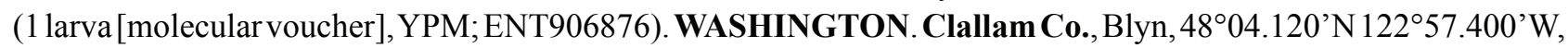
2.iv.2005, coll. Glenn Kohler (1 ㅇ (SDG dissection 1384), CSCA), 9.vi.2005 (1 § (SDG dissection 1274), CSCA). Seguim, $48^{\circ} 06.480^{\prime} \mathrm{N} 123^{\circ} 12.580^{\prime} \mathrm{W}, 25 . v i i .2005$, coll. Glenn Kohler (1 $\left.{ }_{+}, \mathrm{CSCA}\right)$. Clark Co., Vancouver, 45.7037, -122.6695, 23.x.2012, coll. Glenn Kohler, ex. Adelges tsugae on Tsuga heterophylla (2 larvae [molecular voucher], YPM; ENT856464, ENT856471). Island Co., Coupeville, $48^{\circ} 12.050^{\prime} \mathrm{N} 122^{\circ} 37.550^{\prime} \mathrm{W}$, 26.vii.2005, coll. Glenn

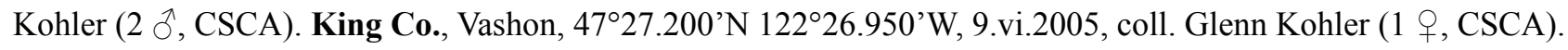
Pierce Co., Ruston, $47^{\circ} 18^{\prime} 02.86^{\prime}$ 'N 122 $2^{\circ} 31^{\prime} 01.31^{\prime \prime}$ W, 7.vii.2010, coll. S.M. Grubin, ex. reared, Adelges tsugae on Tsuga heterophylla, S. Grubin sample SU147, Specimen \#10F867 (1 ठ̊ with puparium [molecular voucher], CSCA),

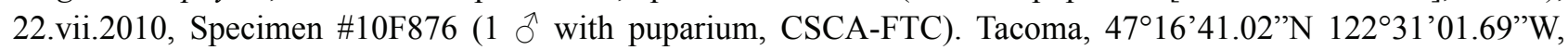
21.vi.2010, coll. S.M. Grubin, ex. Adelges tsugae on Tsuga heterophylla, S. Grubin sample L28 (1 9 with puparium, CSCA), 7.vii.2010, S. Grubin sample L40 (1 $\sigma^{7}$ with puparium, CSCA), 22.vii.2010, S. Grubin sample L42, Specimen \#10F877 ( $1+$ with puparium, CSCA-FTC), no date, S. Grubin sample L54 ( $1+$ with puparium, CSCA). Tacoma, Point Defiance, $47^{\circ} 18.246^{\prime}$ N, $122^{\circ} 30.979^{\prime}$ W, 4.v.2010, coll. S.M. Grubin, ex. reared, Adelges tsugae on 
Tsuga heterophylla, S. Grubin sample SP047, Specimen \#10F694 (1 $\odot$ with puparium, CSCA-FTC), S. Grubin sample SP059, Specimen \#10F693 (1 9 with puparium, CSCA-FTC), 20.v.2010, Specimen \#10F674 (1 $\delta^{\Uparrow}$ with puparium [molecular voucher], CSCA), Specimen \#10F675 (1 § with puparium, CSCA-FTC), S. Grubin sample L20, Specimen \#10F679 (1 $\&$ with puparium, CSCA-FTC), S. Grubin sample L22, Specimen \#10F681 (1 \& with puparium, CSCA-FTC), S. Grubin sample L24, Specimen \#10F680 (1 9 with puparium, CSCA-FTC), S. Grubin sample SP075, Specimen \#10F683 (1 §ै with puparium [molecular voucher], CSCA), S. Grubin sample SP077, Specimen \#10F682 (1 $\delta$ with puparium [molecular voucher], CSCA), 4.vi.2010, Specimen \#10F671 (1 $\delta^{\Uparrow}$ with puparium [molecular voucher], CSCA), Specimen \#10F672 (1 ô with puparium, CSCA-FTC), Specimen \#10F673 ( 1 ठै with puparium, CSCA), S. Grubin sample SP079, Specimen \#10F700 (1 $\delta$ with puparium [molecular voucher], CSCA). Tacoma, Point Defiance, $47^{\circ} 16^{\prime} 41.02$ 'N, 122 31 '1.69”'W, 20.v.2010, coll. S.M. Grubin, ex. reared, Adelges tsugae on Tsuga heterophylla, Specimen \#10F659 (1 $\delta$ with puparium [molecular voucher], CSCA), Specimen \#10F660 (1 $q$ with puparium [molecular voucher], CSCA), Specimen \#10F661 (1 $q$ with puparium, CSCA),

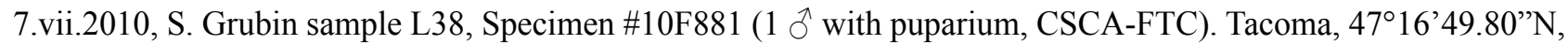
$122^{\circ} 30^{\prime} 58.96^{\prime}$ 'W, 24.iv.2010, coll. S.M. Grubin, ex. reared, Adelges tsugae on Tsuga heterophylla, S. Grubin sample SP009, Specimen \#10F688 (1 + , CSCA-FTC), S. Grubin sample SP029, Specimen \#10F687 (1 $q$ with puparium, CSCA-FTC), 4.v.2010, S. Grubin sample SP064, Specimen \#10F702 (1 $\widehat{\partial}$ with puparium [molecular voucher], CSCA), 9.iv.2010, S. Grubin sample SP011, Specimen \#10F686 (1 $\odot$ with puparium, CSCA), S. Grubin sample SP013, Specimen \#10F685 (1 \&, CSCA-FTC), S. Grubin sample SP017, Specimen \#10F684 (1 \&, CSCA-FTC), 22.vii.2010, S. Grubin sample L56 (1 9 with puparium, CSCA), Specimen \#10F875 (1 $\delta$ with puparium, CSCAFTC). Thurston Co., Olympia, 4701'03.42”N, 122 ${ }^{\circ} 54^{\prime} 10.50^{\prime \prime}$ W, 24.iv.2010, coll. S.M. Grubin, ex. reared, Adelges tsugae on Tsuga heterophylla, S. Grubin sample SP025, Specimen \#10F699 (1 + with puparium [molecular voucher], CSCA), S. Grubin sample SP039, Specimen \#10F695 (1 ô with puparium, CSCA), Specimen \#10698 (1 ô with puparium [molecular voucher], CSCA), S. Grubin sample SP041, Specimen \#10F697 (1 ठิ with puparium [molecular voucher, CSCA), S. Grubin sample SP042, Specimen \#10F696 (1 ô with puparium, CSCA), 5.v.2010, Specimen \#10F676 (1 ô with puparium [molecular voucher], CSCA), Specimen \#10F677 (1 $\&$ with puparium [molecular voucher], CSCA), S. Grubin sample SP060, Specimen \#10F691 (1 ठ̊ with puparium, CSCA-FTC), S. Grubin sample SP062, Specimen \#10F690 (1 + with puparium, CSCA-FTC), S. Grubin sample SP063, Specimen \#10F689 (1 $\delta^{\star}$ with puparium, CSCA-FTC), S. Grubin sample SP065, Specimen \#10F692 (1 + with puparium, CSCA), 20.v.2010, Specimen \#10F662 (1 $\delta^{\lambda}$ with puparium, CSCA), 21.vi.2010, S. Grubin sample SU088, Specimen \#10F869 (1 $\widehat{\delta}$

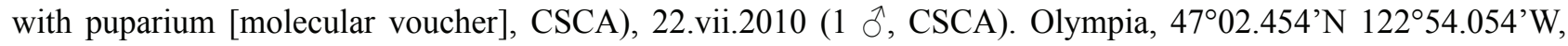
8.vii.2009, coll. S.M. Grubin, ex. reared from Adelges tsugae, N. Havill sample 10-01, Specimen \#10F131 (1 $\delta^{\lambda}$ [molecular voucher], CSCA), N. Havill sample 10-04, Specimen \#10F132 (1 $\lesssim$ [molecular voucher], CSCA), 24.vi.2009, N. Havill sample 10-03, Specimen \#10F130 (1 §ิ [molecular voucher], CSCA), no date, S. Grubin sample L30, Specimen \#10F873 (1 $\delta^{\wedge}$ with puparium, CSCA-FTC). Tumwater, Tumwater Falls Park, 47.0379, -122.896521 , vi.2013, coll. D. Ross, (2 larvae, 3 adults [molecular voucher], YPM; ENT856591, ENT856601 (larvae), YPM; ENT856419, ENT856425, ENT856427). Pierce, King, and Thurston Cos., 11.iv-25.v2015, from lab colony, coll. D. Ross, A. Arsenault, (4 adults [molecular voucher], YPM; ENT791609, ENT791540, ENT791572, ENT791575). WYOMING. Teton Co., Caribou-Targhee National Forest, 43.7047, -110.9847, 18.x.2017, coll. Laura Lowrey, ex. Pineus abietinus on Abies lasiocarpa (5 puparia [molecular voucher], YPM; ENT996085-89).

Leucotaraxis atrifacies (Aldrich), comb. nov.

(Figs 1A, 2C-D, 3B, 3F-G)

Leucopis atrifacies Aldrich 1925: 152. United States. California: San Francisco (HT q, USNM). References - McAlpine 1965: 709 (catalog); Cole \& Schlinger 1969: 376 (note); Tanasijtshuk 2002: 194 (redescription), figs 1-2 (head), figs 3-5 (ठ genitalia); Havill et al. 2018: 26 (relationships).

Diagnosis. The face and lunule (Figs 2C-D) are dark brown to black pruinose. The postpronotum (as in Fig. 2E) has 1 strong postpronotal seta, and no additional setulae longer than those on the scutum. In the male (see figs 3-5 in Tanasijtshuk 2002), the epandrial complex is simple, small, and yellowish- to silvery-grey pruinose, with no central epandrial process; the surstylar lobe is short and stout; the phallus (Fig. 3B) is long and thick in lateral view, less than $8 \mathrm{X}$ longer than its height at the middle, and is straight-sided until an abrupt distal curve to a pointed tip. In the 
female (Fig. 3G), tergite 6 enlarged and about $1.6 \mathrm{X}$ wider than long, tergite 7 present and strap-like, tergite 8 longer than wide, bone-shaped, narrowest through middle; sternites (Fig. 3F) with sternite 6 more than $2 \mathrm{X}$ wider than long and slightly concave medially on both anterior and posterior margins, sternite 7 absent.

Immatures. Egg (Fig. 1A). Length $0.42-0.47 \mathrm{~mm}$, width $0.14-0.17 \mathrm{~mm}$. Puparium. Length $1.9-2.2 \mathrm{~mm}$, width $0.7-0.9 \mathrm{~mm}$. Dehiscent anterior segments (dorsal and ventral) $0.04-0.06 \mathrm{~mm}$ long. Raised posterior spiracular tubercles 0.07-0.11 mm long, with sclerotization concolorous with remainder of puparium (as in Fig. 1D).

Biology. Predators as larvae on species of Adelges and Pineus on Pinaceae (Pinus, Tsuga). Specific records include their attacking Adelges piceae and a Pineus sp., and adelgids (presumably Pineus sp.) infesting Pinus radiata and Pinus edulus. A larva was collected from Pineus coloradensis on Pinus ponderosa. Many specimens were swept from infestations of Cinara ponderosae in young stands of Pinus ponderosa (e.g., height less than $5 \mathrm{~m}$ throughout the large stand), but despite rearing $>150$ chamaemyiid larvae from this host, none were this species but were instead Vitaleucopis nidolkah and an undescribed species of Leucopis (Leucopis). It remains a possibility that Leucotaraxis atrifacies is also a predator in that system, whether on the Cinara aphids or on adelgids unseen by the first author while collecting.

Remarks. This species was originally described from specimens reared by Eric Walther "in connection with Thecodiplosis pini-radiatce" (=Thecodiplosis piniradiatae (Snow \& Mills), Cecidomyiidae), the Monterey pine midge. This midge forms galls at the bases of needles of several species of Pinus including Pinus coulteri, P. radiata and P. sabiniana, and although they likely do not share a true association, it makes sense for them to be together on a tree infested with both the midge and adelgids.

At two different localities (one in New Mexico and one in Arizona), this species was collected together with Chamaethrix necopina, Leucotaraxis argenticollis and Vitaleucopis nidolkah, and at the New Mexico locality also with Leucotaraxis sepiola. This species was also collected at a different New Mexico locality with Leucotaraxis sepiola, and at the southern California locality along with the undescribed species of Vitaleucopis cited in Gaimari (2020). The puparial stage is indistinguishable from that of Leucotaraxis piniperda, both of which are only distinguishable from Leucotaraxis argenticollis by the shorter posterior spiracular tubercle which is not more darkly sclerotized distally, and the slightly smaller size.

Given the few specimens known from Mexico are from the south of the country and quite distant from other known specimens, it is expected that this species inhabits the areas dominated by Pinus in Mexico, at least as far south as the Popocatépetl volcano. More rearing and collecting in Mexico will be necessary to understand the extent of its distribution south of the USA.

Distribution. Mexico (Durango, Mexico State). USA (Arizona, California, Colorado, New Mexico, Washington).

Specimens examined. All specimens from Tanasijtshuk (2002) were examined, with additional specimens as follows. MEXICO: MEXICO. San Pedro Nexapa, nr. Amecameca, foot of Popocatépetl (volcano), 1904'23.89'N 98²'04.04”'W, 2955 m, 7.vii.2011, coll. N.P. Havill, W. Gloria, A. Gloria-Soria, ex. on Pinus sp. (5-needle) infested with Pineus sp. (2 $\widehat{\delta}$ with puparia, CSCA). USA: ARIZONA. Apache Co., Apache National Forest,

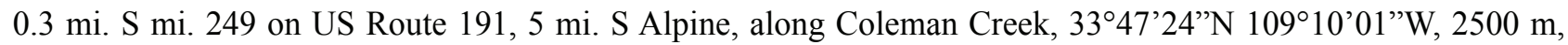
30.vi.1995, coll. S.D. Gaimari, ex. sweep Pinus ponderosa (1 \&, CSCA), 1.vii.1995 (1 q, CSCA); nr. Alpine, 3351'52”N 109¹0'18”'W, 2440 m, 28.vi.1995, coll. S.D. Gaimari, ex. sweep young Pinus ponderosa (1 q, CSCA). CALIFORNIA. Los Angeles Co., La Crescenta, Eagle Canyon, S base Mount Lukens, 29.vi.1994, coll. S.D. Gaimari, ex. Sharkey Malaise trap near stream (1 $\partial^{\lambda}$, CSCA). COLORADO. Alamosa Co., 21 mi. ENE Mosca, $37^{\circ} 45^{\prime} 02^{\prime} \mathrm{N} 105^{\circ} 30^{\prime} 14^{\prime \prime} \mathrm{W}, 8100 \mathrm{ft}$., 19-22.vi.1996, coll. S.D. Gaimari, ex. Malaise trap (1 9 , CSCA). NEW MEXICO. Lincoln Co., Lincoln National Forest, $2.4 \mathrm{~km}$ W Angus, Mills Canyon, along Rio Bonito, 33⒉ $7^{\prime} 05^{\prime}$ 'N 105'41'46”'W, 2130 m, 18-19.vi.1995, coll. S.D. Gaimari, ex. sweep colonies of Cinara ponderosae on Pinus

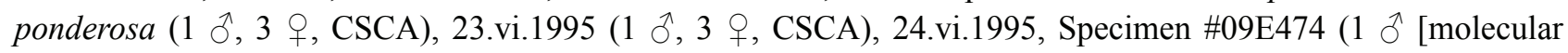
voucher], CSCA), Specimen \#09E478 (1 ठ̊ [molecular voucher], CSCA), Specimen \#09E479 (1 ô [molecular voucher], CSCA), Voucher \#09E519 (2 ð, 8 ค , CSCA-FTC), 25.vi.1995, Specimen \#09E480 (1 $\lesssim$ [molecular voucher], CSCA), Voucher \#09E513 (1 + (SDG dissection \#1379), CSCA-FTC), Specimen \#10F334 (1, CSCA), Specimen \#10F335 (1 q (SDG dissection \#1380), CSCA-FTC), Specimen \#10F336 (1 \& (SDG dissection \#1381), CSCA-FTC), Specimen \#10F337 (1 +, CSCA-FTC), Specimen \#10F338 (1 \&, CSCA-FTC), Specimen \#10F339 (1 + , CSCA-FTC), Specimen \#10F340 (1 + (SDG dissection \#1382), CSCA-FTC), Specimen \#10F341 (1 + (SDG dissection \#1383), CSCA-FTC), Specimen \#10F342 (1 , CSCA-FTC), Specimen \#10F343 (1 q, CSCA-FTC), 
Specimen \#10F344 (1 Ô, CSCA-FTC), Specimen \#10F345 (1 Ô, CSCA-FTC), 26.vi.1995, Specimen \#09E523 (1 $q$ (SDG dissection \#1372), CSCA-FTC), Specimen \#10F346 (1 ㅇ, CSCA-FTC), Specimen \#10F347 (1 q (SDG dissection \#1374), CSCA-FTC), Specimen \#10F348 (1 (SDG dissection \#1375), CSCA-FTC), Specimen \#10F349 (1 + (SDG dissection \#1376), CSCA-FTC), Specimen \#10F350 (1 q (SDG dissection \#1377), CSCAFTC), Specimen \#10F351 (1 + (SDG dissection \#1378), CSCA-FTC), Specimen \#10F353 (1 9 (SDG dissection \#1372), CSCA-FTC), Specimen \#10F726 (1 $\overbrace{}^{2}$, CSCA), Voucher \#09E515 (5 + , CSCA-FTC); White Mountains, along Fork Creek, 3.1 mi. W Alto, 33²3’31.2”N 10543'57.0”'W, 2365 m, 15.vi.2007, coll. S.D. Gaimari, ex. sweep Pinus ponderosa with Cinara ponderosae infestation (1 $\delta^{\lambda}, 1$, , CSCA). McKinley Co., Cibola National Forest,

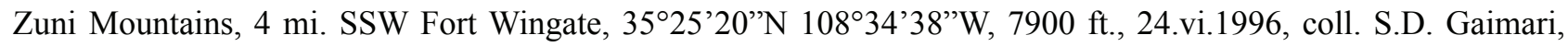

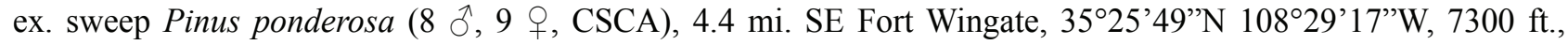
25.vi.1996, ex. sweep Pinus edulus (4 + , CSCA). WASHINGTON. Ferry Co., Colville Reservation, Inchelium, 48.3109 ${ }^{\circ}$ 118.2017 ${ }^{\circ}$ W, 22.vii.2019, coll. D. Dickenson, ex. Pineus coloradensis on Pinus ponderosa, sample 19176-05 (1 $\mathrm{o}^{\wedge}$, on slide, YPM; ENT960794).

\section{Leucotaraxis piniperda (Malloch), comb. nov.}

(Figs 1D, 2E-H, 3C, 3H)

Leucopis piniperda Malloch 1921: 351. United States. Illinois: Urbana (HT + , INHS). References - McAlpine 1965 : 709 (catalog); Cole \& Schlinger 1969: 376 (note); Tanasijtshuk 2002: 203 (redescription), figs 29-30 (head), figs 31-34 (ठ઼ genitalia). Kohler et al. 2008: 494 (biology, as Leucopis atrifacies); Grubin et al. 2011: 1410 (biology); Havill et al. 2018 (biology, population genetics); Neidermeier et al. 2020 (biology, biological control); Dietschler et al. 2021 (biology, biological control).

Diagnosis. The lunule, face and parafacial are either entirely silvery-grey pruinose (Fig. 2F, eastern form), entirely brown to black pruinose (Fig. 2H, western form), or the lunule and face are brown to black pruinose with the parafacial silvery-grey pruinose (Fig. 2G, mixed form). The postpronotum (Fig. 2E) has 1 strong postpronotal seta, and no additional setulae longer than those on the scutum. In the male (see figs 31-34 in Tanasijtshuk 2002), the epandrial complex is simple, small, and yellowish- to silvery-grey pruinose, with no central epandrial process; the surstylar lobe is short and stout; the phallus (Fig. 3C) is very long and thin in lateral view, more than $10 \mathrm{X}$ longer than its height at the middle, and is gently curved throughout to a pointed tip. In the female (Fig. $3 \mathrm{H}$ ), tergite 6 enlarged and about $1.5 \mathrm{X}$ wider than long, tergite 7 absent (position represented only by tiny setulae), tergite 8 longer than wide, parallel-sided, with distal end enlarged; sternites as in Leucotaraxis atrifacies (Fig. 3F).

Immatures. Egg and puparium as in Leucotaraxis atrifacies.

Biology. Predators as larvae on species of Adelges and Pineus on Pinaceae (Abies, Picea, Pinus). Specific records (including our own rearings) include: Adelges piceae on Abies grandis; Adelges tsugae on Tsuga heterophylla (Kohler et al. 2008); Pineus boerneri on Pinus densiflora; Pineus coloradensis on Pinus sp. (a 5-needle pine, possibly Pinus lambertiana) and Picea engelmannii; Pineus pini on Pinus sylvestris; Pineus similis on Picea glauca; Pineus strobi on Pinus strobus (Tanasijtshuk 2002; Wantuch et al. 2019); Pineus sp. on Pinus sylvestris. They have also been collected as adults from Pinus contorta and Pinus resinosa.

Remarks. Unfortunately, the few specimens from Oregon and Washington in the study by Kohler et al. (2008) were misidentified as Leucopis atrifacies. After examination of the specimens from this work and from Tanasijtshuk (2002), the color of pruinosity on the lunule, face and parafacial are variable, with a distinct distributional pattern. The specimens from eastern North America (Canada - New Brunswick, Quebec; USA - Connecticut, Illinois, Maryland, Minnesota, North Carolina, Ohio, Rhode Island, Virginia) all have uniformly silvery-grey pruinosity (Fig. 2F), while those in western North America (Canada - Alberta, British Columbia; USA - California, Colorado, Idaho, New Mexico, Oregon, Washington, Wyoming) all have uniformly brown to black pruinosity (Fig. $2 \mathrm{H}$ ). The east-west divergence is also displayed in molecular data (see Havill et al. 2018). Only the specimens from Ontario, Canada, have a mixed state (Fig. 2G), with the lunule and face being brown to black pruinose with the parafacial silvery-grey pruinose. Both the male and female genitalia, as well as other external characteristics, make the identity of this species unambiguous despite this variation. The puparial stage is indistinguishable from that of Leucotaraxis atrifacies, both of which are only distinguishable from Leucotaraxis argenticollis by the shorter posterior spiracular tubercle that is not heavily sclerotized distally, and the slightly smaller size. 
Distribution. Canada (Alberta, British Columbia, New Brunswick, Ontario, Quebec, Saskatchewan). USA (Arizona, California, Colorado, Connecticut, Idaho, Illinois, Maryland, Massachusetts, Michigan, Minnesota, New Mexico, New York, North Carolina, Ohio, Oregon, Pennsylvania, Rhode Island, Utah, Virginia, Washington, West Virginia).

Specimens examined. All specimens from Tanasijtshuk (2002) were examined, with additional specimens as follows. CANADA: ALBERTA. Seebe, 20.i.1971, ex. duff around C. com. infected $P[$ inus]. contorta, \#2670 (1 + , CNC). ONTARIO. Chalk River, 1.viii.1951, coll. J.M. Anderson, ex. Pissodes strobi (1 + CNC). Ottawa, 29.vi.1994, coll. J.R. Vockeroth, ex. damp second-growther Acer-Betula woods (1 q, CNC). Sault Ste. Marie, 18. vii.1951, coll. L. Lyons, ex. red pine [=Pinus resinosa], No. R-70-19 (1 9 , CNC). SASKATCHEWAN. Smeaton, 53.6181, -104.7409, 9.vi.2010, coll. N. Havill, ex. Pineus on Picea sp. (1 larva [molecular voucher], YPM; ENT764124). USA. CALIFORNIA. EI Dorado Co., Eldorado National Forest, 38.9148, -120.3904, 31.v.2010, coll. Nathan Havill, Stephen Gaimari, ex. Pineus coloradensis on Pinus sp. (5-needle) (1 larva [molecular voucher], YPM; ENT790140). COLORADO. Boulder Co., Boulder, Flagstaff Canyon, 5800 ft., 10.vi.1961, coll. C.H. Mann, ex. on side of stream (1 $\left.{ }^{\top}, \mathrm{CNC}\right)$. Larimer Co., Zimmerman Lake trail, 40.5397, -105.8792, 27.vii.2016, coll. Nathan Havill, ex. Pineus coloradensis on Picea engelmannii (1 larva [molecular voucher], YPM; ENT857046). CONNECTICUT. Hartford Co., Hartford, Cedar Hill Cemetery, 41.7266, -72.6932, 5.vi.2016, coll. M.E. Montgomery, ex. Pineus strobi on Pinus strobus (8 larvae [molecular voucher], YPM; ENT961079-86). New Haven Co., Hamden, Exeter Rd. \& Deerfield Dr., $41.426^{\circ} \mathrm{N} 72.936^{\circ} \mathrm{W}$, 16.vi.2009, coll. M.E. Montgomery, ex. reared from Pineus sp. on Pinus sylvestris, N. Havill sample 09-134, Specimen \#09E471 (1 $\hat{\delta}$ [molecular voucher], CSCA). IDAHO. Idaho Co., Warm Springs Point, 13.viii.1969, 51-488b (2 + , USNM). ILLINOIS. Champaign Co. Urbana, 12.vi.1967, coll. J. Appleby, ex. larvae in wax mass of pine aphid (1 $q$ with puparium, 2 , USNM). Morgan Co., Meredosia, 29.v.1917 (1 +, INHS). MARYLAND. Baltimore Co., Baltimore, Cylburn Arboretum, 39.532, -76.653, 28.v.2008, coll. Melody Keena, ex. Pineus boerneri on Pinus densiflora (7 larvae [molecular voucher], YPM; ENT856378-84). MASSACHUSETTS. Hampshire Co., Amherst, 42.3928, -72.5323, 20.v.2018, coll. Ryan Crandall, ex. Pineus strobi on Pinus strobus (1 larva [molecular voucher], YPM; ENT996097). Worcester Co., Worcester, 42.2790, -71.7733, 12.v.2018, coll. Felicia Andre, ex. Pineus strobi on Pinus strobus (1 larva [molecular voucher], YPM; ENT996096). MICHIGAN. Benzie Co., Lake Ann, 44.7436, -85.9131, 6.xi.2018, coll. Scott Lint, ex. Pineus strobi on Pinus strobus (2 puparia [molecular voucher], YPM; ENT996098-99). MINNESOTA. Beltrami Co., Bemidji, visitor center nr. Paul Bunyan statue, 47²8’13”N 9452’43”W, 23.v.2009, coll. N. Havill, ex. old gall of Adelges sp. on Picea sp., N. Havill sample 09-123, Specimen \#09E475 (1 ठ [molecular voucher], CSCA). NEW MEXICO: San Miguel Co., Las Vegas Hot Springs, 7.viii, coll. H.S. Barber (1 $\partial^{\lambda}$, USNM). NEW YORK. Cayuga Co., McIlroy Bird Sanctuary, 42.6661, -76.2834, 2.vii.2019, coll. Nicholas Dietschler, Marshall Lefebvre, Katharine O'Connor, ex. Pineus strobi on Pinus strobus (1 puparium [molecular voucher], CUIC). Monroe Co., Rochester, Highland Park, 43.1278, -77.6122, 8.vii.2017, coll. Cynthia Smith, ex. Pineus strobi on Pinus strobus (3 larvae, 13 puparia [molecular voucher], CUIC). Steuben Co., Addison, McCarthy Hill State Forest, 42.0975, -77.1938, 26.vii.2018, coll. Nicholas Dietschler, Marshall Bigler-Lefebvre, ex. Pineus strobi on Pinus strobus, (7 larvae, 2 puparia [molecular voucher], CUIC). Tompkins Co., Ithaca, Cornell campus, 42.4454, -76.4755, 3.vi.2016, coll. Nathan Havill, Mark Whitmore, Amalia Havill, ex. Pineus strobi on Pinus strobus (12 larvae [molecular voucher], YPM; ENT856925-36). Ulster Co., Woodstock, Overlook Mountain Forest, 42.0760, -74.1259, 31.v.2018, coll. Nicholas Dietschler, Marshall Bigler-Lefebvre, ex. Pineus strobi on Pinus strobus (5 larvae [molecular voucher], CUIC). NORTH CAROLINA. Macon Co., Highlands, Wightman College, 10. vii.1987, coll. W.W. Wirth, ex. UV light (1 \&, USNM). Transylvania Co., Sapphire, 20.vii.1990, coll. W.W. Wirth, ex. UV light trap (2 q, USNM). OHIO. Morgan Co., Beverly, 39.6431,-81.7060, 26.vi.2019, coll. Page Weckbacher, ex. Pineus strobi on Pinus strobus (1 larva, 4 puparia [molecular voucher], YPM; ENT961088-92). Portage Co., Kent, 16.vii.1969, coll. T.P. Sluss, biological note 6914 (1 ڤึ, UAIC). OREGON. Benton Co., Corvallis, 12.v.1951, coll. R.G. Mitchell, ex. reared, predaceous on Adelges piceae (1 ô, CNC). Multnomah Co., Portland, Grant Park, $45^{\circ} 32.450^{\prime} \mathrm{N} 122^{\circ} 37.800^{\prime} \mathrm{W}, 14$. iv.2006, coll. G. Kohler, ex. reared from field collected puparium on Adelges tsugae (1 $\delta^{\lambda}$ with puparium, CSCA), 12.v.2006, ex. flight caught ( 2 , CSCA). PENNSYLVANIA. Greene Co., Mt. Morris, 39.7730, -80.1475, 19.vi.2015, coll. Andrew Liebhold, ex. Pineus strobi on Pinus strobus (2 larvae [molecular voucher], YPM; ENT856919, ENT856697). RHODE ISLAND. Washington Co., University of Rhode Island, Kingston, 12.vi.1982, coll. R. Casagrande (1 $\widehat{\jmath}$, USNM). UTAH. Davis Co., Farmington Canyon, 40.9932, -111.8186, 5.ix.2017, coll. Danielle Malesky, ex. Adelges piceae on Abies lasiocarpa (1 larva [molecular voucher], 
YPM; ENT996095). VIRGINIA. Fairfax Co., Alexandria, 14.vi.1952, coll. W.W. Wirth (1 \&, USNM), 15.vi.1952 (1 ô, USNM). Montgomery Co., Blacksburg, Coal Mining Heritage Park, 37.1870, -80.427, 18.v.2010, coll. Melissa Fischer, ex. Pineus strobi on Pinus strobus. (9 larvae [molecular voucher], YPM; ENT856988-89, ENT856702-08). WASHINGTON. Clark Co., Vancouver, 45.7031, -122.6707, 21.vi.2013, coll. Darrell Ross, ex. Adelges tsugae on Tsuga heterophylla (1 larva [molecular voucher], YPM; ENT856663). Island County; Camano Island, 48.1474,-122.4411, 4.iv.2017, coll. Mark Whitmore, Isis Caetano, ex. Adelges tsugae on Tsuga heterophylla

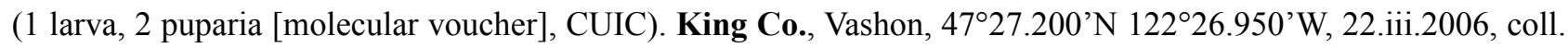
G. Kohler, ex. reared from field collected puparium on Adelges tsugae ( 1 with puparium, CSCA), S. Grubin sample L48, Specimen \#10F865 (1 ô with puparium [molecular voucher], CSCA), 4.viii.2010, coll. S.M. Grubin, ex. reared, Adelges tsugae on Tsuga heterophylla, Specimen \#10F880 ( 1 q with puparium, CSCA-FTC). Pierce Co., Ruston, $47^{\circ} 18^{\prime} 02.86^{\prime}$ N $122^{\circ} 31^{\prime} 01.31^{\prime \prime W}, 22$.vii.2010, coll. S.M. Grubin, ex. reared, Adelges tsugae on Tsuga

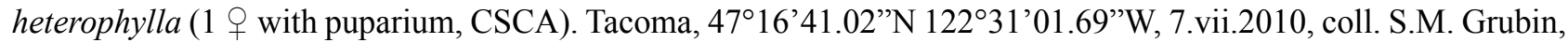
ex., reared, Adelges tsugae on Tsuga heterophylla, S. Grubin sample L44 (1 Oे, CSCA), S. Grubin sample SU132 (1 $\widehat{\partial}$ with puparium, CSCA), 22.vii.2010 (2 $\widehat{\partial}$ with puparia, 1 \& with puparium, CSCA), S. Grubin sample L50 (1 $\delta$ with puparium, CSCA), S. Grubin sample SU180 (1 ठิ with puparium, CSCA), S. Grubin sample SU181, Specimen 10F864 ( $1 \hat{\sigma}$ with puparium [molecular voucher], CSCA), Specimen \#10F874 (1 + with puparium, CSCA-FTC),

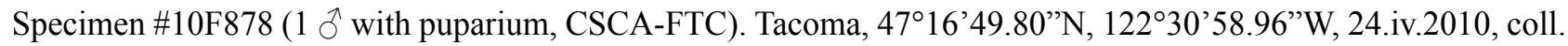
S.M. Grubin, ex. reared, Adelges tsugae on Tsuga heterophylla ( 2 o with puparia, 2 q with puparia, CSCA), Specimen \#10F663 (1 $\delta$ with puparium [molecular voucher], CSCA), Specimen \#10F664 (1 $\delta$ with puparium [molecular voucher], CSCA), Specimen \#10F665 (1 $\hat{\jmath}$ with puparium, CSCA). Tacoma, Masonic Memorial Cemetery, 1.i.2016, coll. Rachel Brooks (2 larvae [molecular voucher], YPM; ENT856920-21). Tacoma, Point Defiance Park, 47.304, -122.516, 12.v.2008, coll. Michael E. Montgomery, Richard McDonald (2 adults [molecular

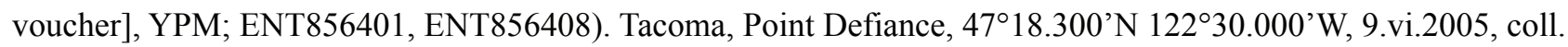
G. Kohler (1 +, CSCA). Tacoma, Point Defiance, $47^{\circ} 18.246^{\prime}$ N $122^{\circ} 30.979^{\prime} W, 25 . i v .2009$, coll. S.M. Grubin, ex. reared, Adelges tsugae on Tsuga heterophylla, N. Havill sample 10-05.1, Specimen \#10F135 (1 $q$ [molecular voucher], CSCA), N. Havill sample 10-05.2, Specimen \#10F133 (1 ㅇ [molecular voucher], CSCA), N. Havill sample 10-05.3, Specimen \#10F138 (1 ठ ${ }^{\lambda}$ [molecular voucher], CSCA), N. Havill sample 10-05.4, Specimen \#10F134 (1 q [molecular voucher], CSCA), N. Havill sample 10-05.5, Specimen \#10F137 (1 ठ̊ [molecular voucher], CSCA), 24.iv.2010, S. Grubin sample SP023, Specimen \#10F655 (1 ô with puparium, CSCA), 5.v.2010, Specimen \#10F656 (1 $\delta$ with puparium [molecular voucher], CSCA), Specimen \#10F657 (1 $\&$ with puparium [molecular voucher], CSCA), Specimen \#10F658 ( 1 q with puparium, CSCA-FTC). Thurston Co., Olympia, 4701'03.42”N, 122 54'10.50”'W, 24.iv.2010, coll. S.M. Grubin, ex. reared, Adelges tsugae on Tsuga heterophylla, Specimen \#10F666 (1 $\delta$ with puparium [molecular voucher], CSCA), Specimen \#10F667 (1 q with puparium [molecular voucher], CSCA), Specimen \#10F668 (1 q with puparium, CSCA-FTC), Specimen \#10F669 (1 $\delta$ with puparium, CSCA), Specimen \#10F670 (1 $q$ with puparium, CSCA), 5.v.2010, Specimen \#10F678 (1 q with puparium [molecular voucher], CSCA), 21.vi.2010, S. Grubin sample SU120, Specimen \#10F868 (1 $\delta^{\lambda}$ with puparium [molecular voucher], CSCA), 7.vii.2010, S. Grubin sample SU166 (1 $q$ with puparium, CSCA), S. Grubin sample SU162, Specimen \#10F879 ( 1 o with puparium, CSCA-FTC), 22.vii.2010 ( 1 q with puparium, CSCA). Olympia, $47^{\circ} 00^{\prime} 48.30^{\prime} \mathrm{N} 122^{\circ} 54^{\prime} 18.21^{\prime \prime} \mathrm{W}, 8$.vii.2010, coll. S.M. Grubin, ex. reared, Adelges tsugae on Tsuga heterophylla, S. Grubin sample L34 (1 $\&$ with puparium, CSCA). Olympia, $47^{\circ} 02.454^{\prime} \mathrm{N} 122^{\circ} 54.054^{\prime} \mathrm{W}, 29$.vii.2009, coll. S.M. Grubin, ex. reared from Adelges tsugae, N. Havill sample 10-02, Specimen \#10F136 (1 \& [molecular voucher], CSCA). Pierce, King, and Thurston Cos., 11.iv-25.v.2015, from lab colony, coll. Darrell Ross, Arielle Arsenault, (4 adults [molecular voucher], YPM; ENT791591, ENT791607, ENT791616, ENT791620). WEST VIRGINIA. Jefferson Co., Shepherdstown, U.S. Fish \& Wildlife National Conservation Training Center, 39.486, -77.805, 28.v.2008, coll. Melody Keena, ex. Pineus strobi on Pinus strobus (3 9 [molecular voucher], YPM; ENT85638789). MISC. Oregon/Washington. Cage reared on Adelges tsugae, v-vii.2006, G. Kohler (1 $\jmath^{\jmath}, 3$, , CSCA). 
Leucotaraxis sepiola sp. nov.

urn:lsid:zoobank.org:act:462348DE-B22C-4463-A4CB-91FB7D1F4AD0

(Figs 4A-H, 5A-C)

Etymology. From the diminutive of the Latin noun sepia, referring to squid ink, in reference to the large, distinctive, shiny black epandrium and cerci in the male of this species; a noun.

Diagnosis. The face and lunule (Figs 4B, D) are dark brown to black pruinose. The postpronotum (Figs 4A, G) has 1 strong postpronotal seta, and no additional setulae longer than those on the scutum. In the male genitalia (Figs $5 \mathrm{~A}-\mathrm{C}$ ), the epandrial complex is large, conspicuous and polished black, with the epandrium extending into a central process bearing the cerci at a distinct upward angle; the surstylar lobe is articulated with the epandrium and is long and thin.

Adults, $\widehat{O}$ ( $q$ unknown). Body length $1.8 \mathrm{~mm}$.

Head (Figs 4B-F). 1.4 X higher than long; $1.3 \mathrm{X}$ wider than high; mostly dark silvery grey with exceptions following. Vertex with outer vertical seta longer than inner one by $1.5 \mathrm{X}$. Postocellar setae absent. Ocellar triangle tapering to about midpoint of frons, slightly raised from fronto-orbital plate; posterior ocelli farther apart than distance to anterior ocellus by $1.5 \mathrm{X}$; anterior ocellus slightly smaller than posterior; posterior ocelli placed slightly anterior to vertex, with area between and behind posterior ocelli lacking setulae. Ocellar setae absent. Eye with length and width subequal; height $2.6 \mathrm{X}$ genal height. Frons with reddish grey strip along edge of ocellar triangle (Fig. 4F); $1.3 \mathrm{X}$ wider than long; with lateral edges only slightly diverging anteriorly, $1.1 \mathrm{X}$ wider at level of lunule than at level of anterior ocellus; meeting lunule at $90^{\circ}$ angle. Fronto-orbital setae lacking; area setulose (setulae erect, white) distally (Figs 4C, E). Lunule (Figs 4B-D) dark brown pruinose above antennae; anterior edge straight, height $0.5 \mathrm{X}$ frons length; with few small, fine setulae. Antennae entirely dark brown to black; separated by distance less than $0.5 \mathrm{X}$ antennal socket width, lacking carina, with area between antennal bases darkening to black pruinose ventrally (as in face); 1st flagellomere short, rounded, covered with short brown hairs; arista with distal segment 3.0 X longer than basal. Face black pruinose; with deep antennal grooves. Parafacial black pruinose; about half width of facial width. Gena with one strong genal seta in addition to one strong setula and several small setulae behind. Clypeus black with sparse covering of dark grey pruinosity; small, exposed. Palpus dark brown; cylindrical; setulose. Mouthparts very small and held within oral cavity above palpi; prementum dark, small; labellum small, yellow.

Thorax (Figs 4A, D). Scutum uniformly dark silvery-grey pruinose; $1.3 \mathrm{X}$ longer than wide; $4.0 \mathrm{X}$ scutellar length; setulose; dorsocentral vittae absent. Prescutellum present. Scutellum concolorous with scutum; $1.7 \mathrm{X}$ wider than long. Pleuron concolorous with scutum. Chaetotaxy: 0+2 dorsocentral setae, posterior seta $1.5 \mathrm{X}$ longer than anterior one; one postpronotal seta; two notopleural setae, in anterior and posterior corners, anterior one $3.0 \mathrm{X}$ longer than posterior one; one pre- and one postsutural supra-alar seta; two postalar setae; prescutellar acrostichal seta absent; proepisternum, anepisternum and anepimeron lacking setae; one strong katepisternal seta along upper edge, with 3 or 4 small setulae in row anterior to seta; two pairs scutellar setae. Legs. Entirely dark brown, except for femora and tibiae dark grey pruinose with orange distal tips of femora and basal parts of tibiae, with basal parts of basotarsomeres lighter brown. Wing. Length $1.6 \mathrm{~mm} ; 2.6 \mathrm{X}$ longer than wide. Hyaline, with veins brown. Veins $\mathrm{R}_{2+3}, \mathrm{R}_{4+5}$ and $\mathrm{M}_{1}$ parallel in distal half of wing. Crossvein r-m located slightly basad of halfway point of wing length, and at $3 / 5$ point of cell dm length. Vein $\mathrm{CuA}_{1}$ extends to wing margin; apical section $2.0 \mathrm{X}$ longer than crossvein dm-cu. Halter yellow, with stalk slightly darker.

Abdomen (Fig. 4H). Tergites uniformly setulose, except setulae very slightly enlarged along posterior margin and laterally. Syntergite $1+2$ and tergite 3 bronzy pruinose, except lateral parts dark silvery-grey pruinose; tergites 4-6 dark silvery-grey pruinose. Syntergite $1+2$ and tergite 3 lacking patch of microtrichiae on lateral edge. Sternites dark silvery-grey pruinose.

Male genitalia (Figs 5A-C). Epandrium large, convex posteriorly, entirely shiny black, with series of very small setulae along posterior edge; extending distomedially into blunt projection which bears cerci on ventral surface, with small central depression on anterodorsal surface; with long, narrow, medially-oriented surstylar lobe. Cercus large, padlike; shiny black, oriented downwards from posterior surface of distomedial extension of epandrium; in lateral view, subequal in size and general shape to hypandrium. (Note, phallus complex severely over-macerated after soaking in $\mathrm{KOH}$ with heavy and dark epandrial complex, resulting in the structures shrivelling and becoming twisted. As such, the following characteristics were not illustrated, but are described as well as possible after thorough examination, to be verified when this species is again collected: Hypandrium in dorsal view subovate, $1.3 \mathrm{X}$ longer than wide, 


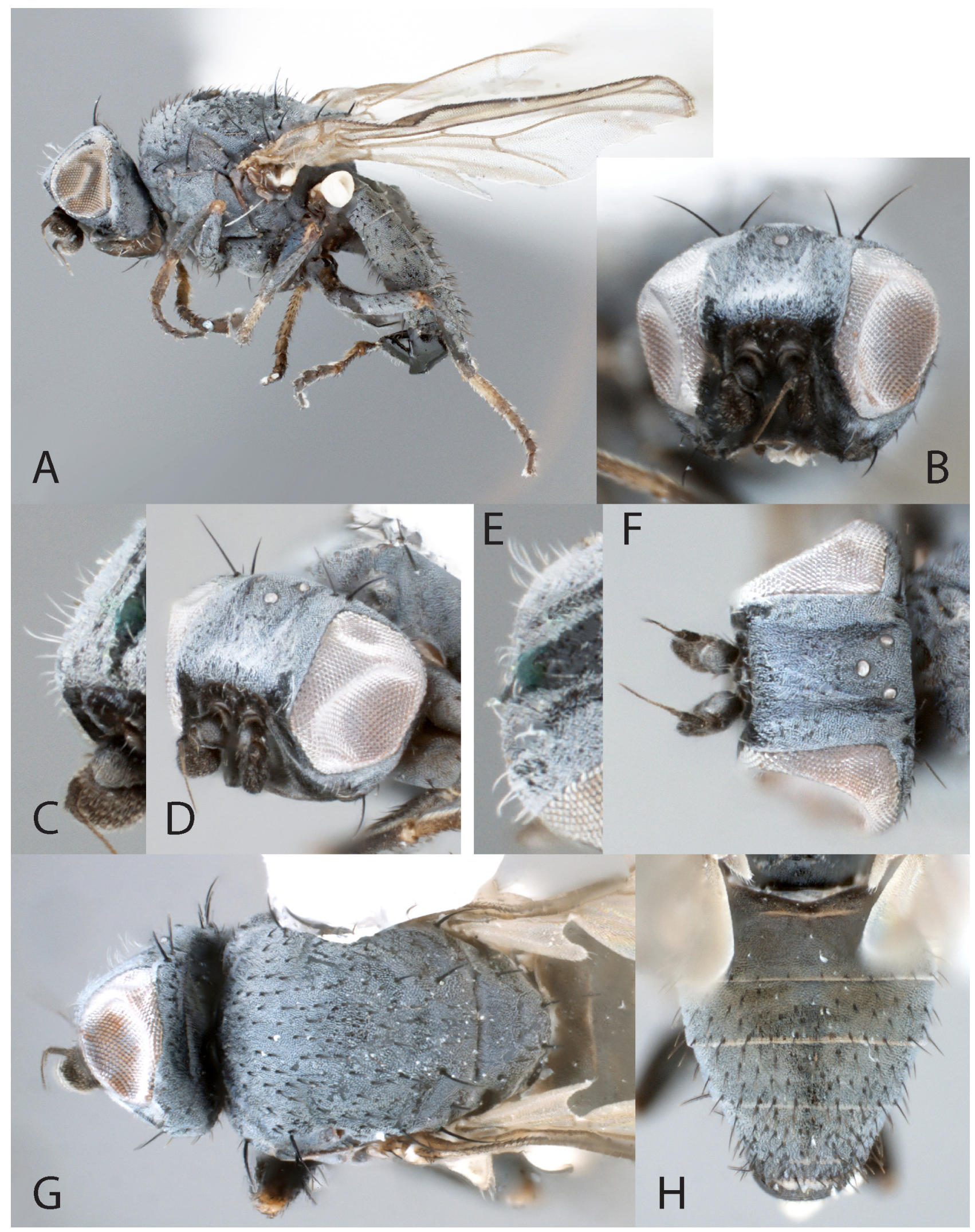

FIGURE 4. Leucotaraxis sepiola, male, external features. A. Habitus, lateral view (paratype). B-F. Head: B. anterior view (holotype); C-D. oblique view: C. showing setae along edge of frons (paratype); D. entire (holotype); E-F. dorsal view: E. showing setae along edges of frons (paratype); F. entire (holotype); G-H. dorsal view (holotype): G. head and thorax; H. abdomen. 


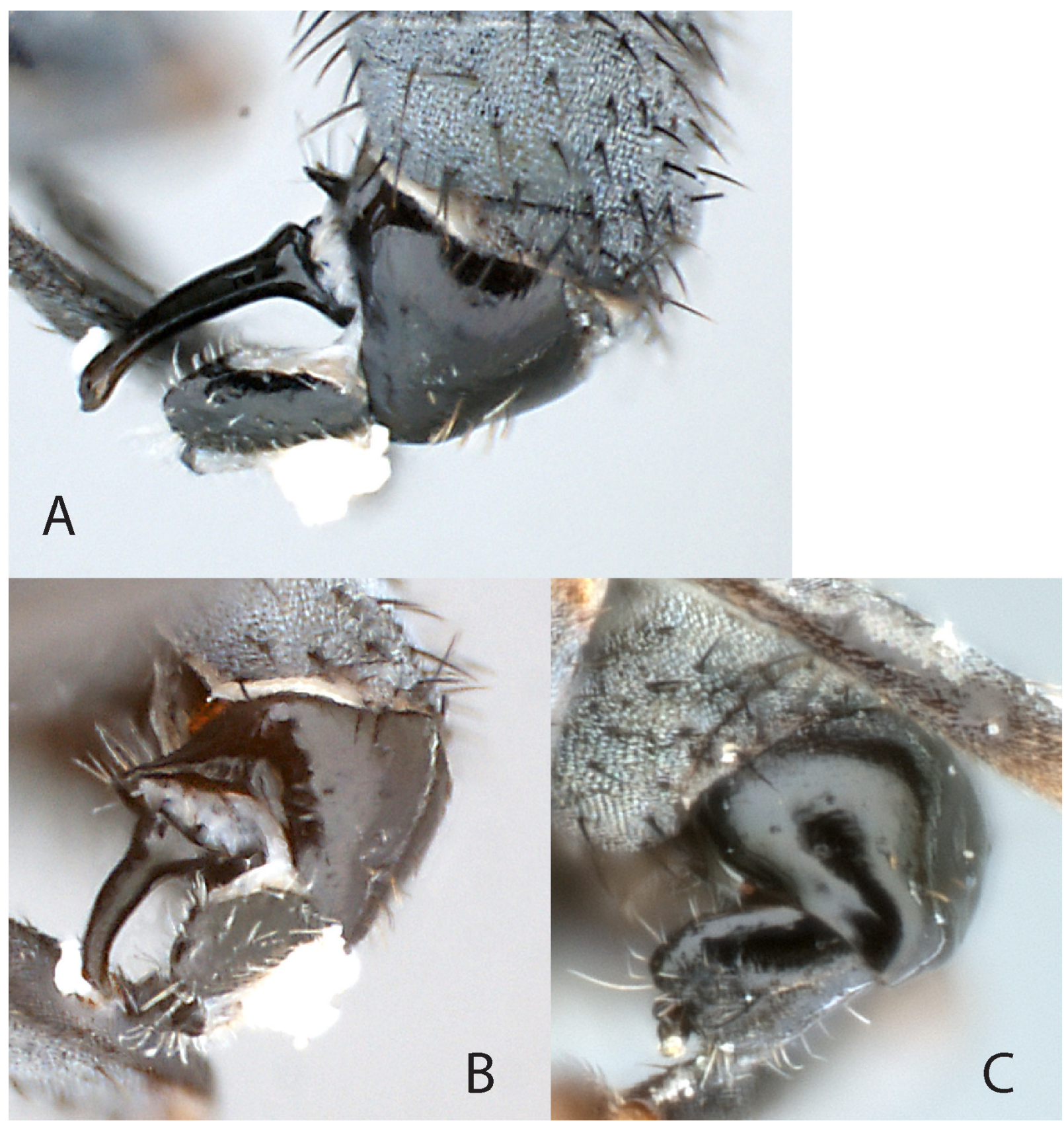

FIGURE 5. Leucotaraxis sepiola, male, genitalic features. A-B. Holotype: A. lateral view; B. posterolateral view. C. Paratype, posterolateral view, with surstylus oriented medially under cercus.

with lateral arms very thick to point of articulation with postgonite, becoming abruptly thin posteriorly; in profile, subquadrate, evenly wide. Pregonite absent. Postgonite flattened, curved, with blunt tip; dorsally setulose; lightly sclerotized. Phallapodeme about $2 \mathrm{X}$ longer than high from lateral view, parallel-sided; in ventral view, bone-shaped, about $3 \mathrm{X}$ longer than wide. Phallus from ventral view parallel-sided to blunt tip, $2.2 \mathrm{X}$ longer than wide; from lateral view, length $4.0 \mathrm{X}$ height of basiphallus, basiphallus extending into small subtriangular lobe, distiphallus slightly curved, evenly narrow to blunt tip).

Immatures. Unknown.

Biology. All known specimens were swept from infestations of Cinara ponderosae in young stands of Pinus ponderosa (e.g., height less than $5 \mathrm{~m}$ throughout the large stand), but despite rearing $>150$ chamaemyiid larvae from this host, none were this species, but were instead Vitaleucopis nidolkah and an undescribed species of Leucopis (Leucopis). It remains a possibility that Leucotaraxis sepiola is a predator in that system, whether on the Cinara aphids or on adelgids unseen by the first author while collecting. 
Remarks. At one locality in New Mexico, this species was collected together with Chamaethrix necopina, Leucotaraxis argenticollis, Leucotaraxis atrifacies and Vitaleucopis nidolkah, and at an additional New Mexico locality along with Leucotaraxis atrifacies.

Distribution. Known only from New Mexico.

Type material. Holotype $\widehat{\delta}$ (point mounted, very good condition), deposited in CSCA, with the following labels: "USA. NEW MEXICO. Lincoln Co., 2.4 km W Angus, Lincoln Nat'1 For., White Mts. Wilderness, head of Mills Cyn. trail along Rio Bonito, el. 2130 m, 3327’05”N 10541’46”W, 26 JUN 1995, S.D. Gaimari, ex. sweep Cinara ponderosae on Pinus ponderosa" / "HOLOTYPUS $\widehat{\jmath}$ Leucotaraxis sepiola Gaimari" (red label). Paratypes: USA: NEW MEXICO. Lincoln Co., 2.4 km W Angus, Lincoln National Forest, White Mountains Wilderness,

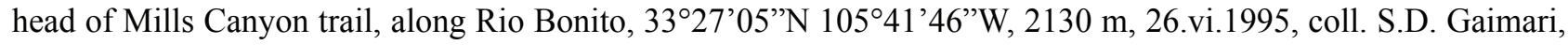
ex. sweep Cinara ponderosae on Pinus ponderosa [same data as holotype], Specimen \#10F352 (1 $\widehat{\jmath}$ [molecular voucher] (SDG dissection 1371), CSCA). McKinley Co., 4 mi. SSW Fort Wingate, Cibola National Forest, Zuni

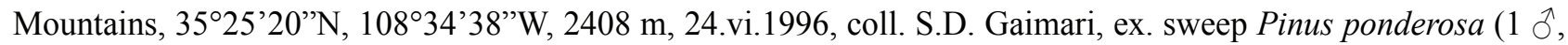
CSCA).

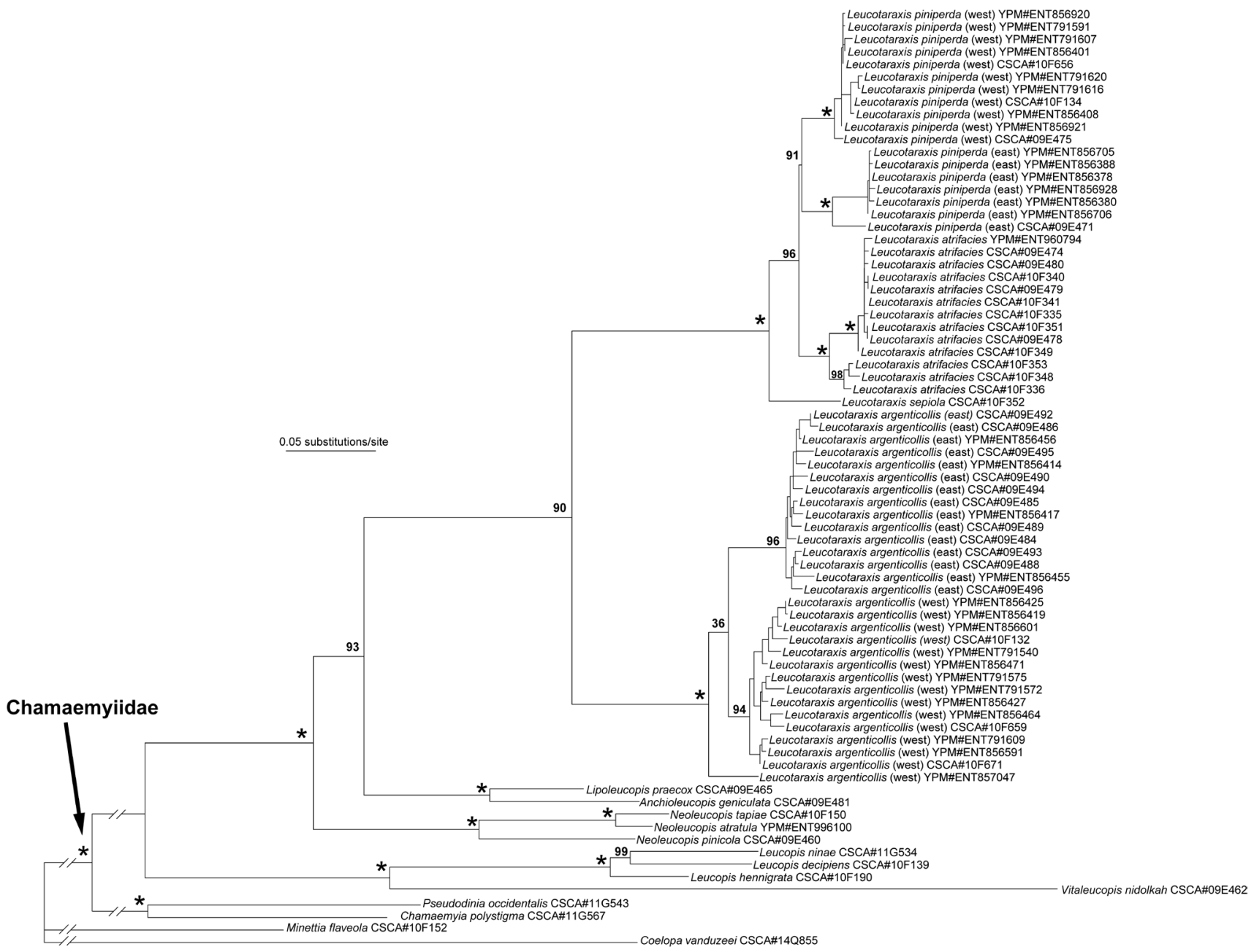

FIGURE 6. Phylogeny of Leucotaraxis showing its position in Chamaemyiidae and the relationships among species. Maximum likelihood tree inferred from the concatenated alignment of one mitochondrial and two nuclear genes. The numbers at the major nodes show the UFBoot support values (* for $100 \%$ ).

\section{Molecular phylogeny}

COI sequences were generated for all specimens included in the phylogeny. TPI sequences were generated for all specimens but Minettia flaveola plus 11 of 13 Leucotaraxis atrifacies, and CAD sequences were generated for all specimens but 11 of 13 L. atrifacies. The lack of TPI and CAD data for some L. atrifacies specimens should not 
impact its placement in the phylogeny because these genes are less variable than COI, and their inclusion for two representatives of the species acts as a 'backbone' for higher-level relationships (Talavera et al. 2021). The topology of the maximum likelihood tree (Fig. 6) shows strong support for the monophyly of Leucotaraxis. This new genus is not sister to Leucopis, to which Leucotaraxis argenticollis, L. atrifacies, and L. piniperda previously belonged. Leucotaraxis atrifacies is sister to L. piniperda, consistent with these species being morphologically similar. As previously reported in Havill et al. (2018), both L. argenticollis and L. piniperda have distinct western and eastern clades in North America. In the West, both species can be readily collected feeding on hemlock woolly adelgid, while in the East, they have not been observed feeding on hemlock woolly adelgid. It therefore appears that western and eastern North American populations of these species have different adelgid prey preferences. The new species Lencotaraxis sepiola is sister to the $L$. atrifacies $+L$. piniperda clade, while $L$. argenticollis is sister to those three species. It is worth noting that the phylogeny presented here shows a specimen of L. argenticollis collected from Pineus coloradensis on Picea engelmannii in Colorado, USA (molecular voucher, YPM; ENT857047), as sister to the rest of the species, which raises the possibility of additional intraspecific variation associated with geography and/or prey preference. It will also be interesting to see the possible variation with the as yet unsampled Palearctic populations of $L$. argenticollis.

\section{Key to Chamaemyiidae feeding on Pinaceae-infesting Sternorrhyncha}

Members of Chamaemyiini are not keyed past the second couplet, since all of those with known biology are predators on Sternorrhyncha in grasses, although occasionally species of some genera will go to Sternorrhyncha on Pinaceae for honeydew as an adult sugar source, e.g., Chamaemyia fumicosta Malloch was collected by the first author on several occasions sweeping Cinara-infested ponderosa pine. A list of the species included is provided after the key, annotated with their known biology, distribution, and other relevant information. The taxa in brackets [ ] have not been specifically reared from Pinaceae-attacking Sternorrhyncha, but are considered likely to be predators in this system; further information is provided in the post-key list, and habitus photographs are provide (Figs 7-14) for all of the relevant genera, with those for Leucotaraxis species in Figs 2-5. The taxa in parentheses ( ) are not thought to be associated with Pinaceae, but are included in the key to account for incidental visitors occasionally taken in sweep samples. The key presented below is based upon study of most included species, with some aspects based on modifications of published keys of McAlpine (1971), Papp (2010), and Tanasijtshuk (1986), and notes and draft keys of McAlpine and the first author.

1. Head largely yellow, except for grey pruinose ocellar triangle; eye much longer than high; gena higher than eye height. Prescutellum and presutural supra-alar seta absent. Male with articulated bilobate surstylus and flexible phallus with spinelike

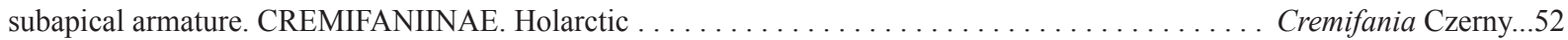
Head color light grey to black, but never yellow; eye dimensions variable, but eye height greater than genal height. Prescutellum present or absent, but presutural supra-alar seta always present. Male usually with fixed non-bilobate surstylus (articulated in Vitaleucopis), phallus rigid and without spinelike armature. $\ldots \ldots \ldots \ldots \ldots \ldots \ldots \ldots \ldots \ldots \ldots \ldots$ CHAMAEMYINAE $\ldots 2$

2 (1). Body elongate, tapering posteriorly. Head with lunule low, bare; 1 or 2 strong fronto-orbital setae present; postocellar setae present; ocellar setae strong, proclinate (absent or minute in some species of Plunomia Malloch and Pseudodinia Melander).

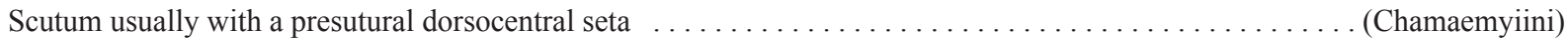
Body compact, stout posteriorly. Head with lunule high and often with setulae; fronto-orbital setae present or absent, sometimes with 1 or 2 enlarged setulae on upper part of fronto-orbital area; postocellar setae absent; ocellar setae absent or small. Scutum

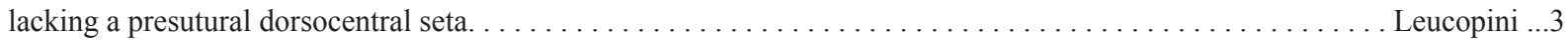

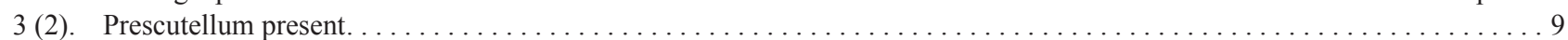

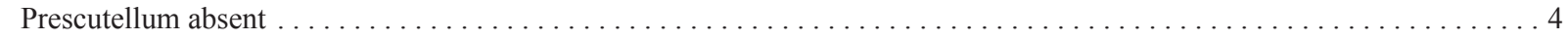

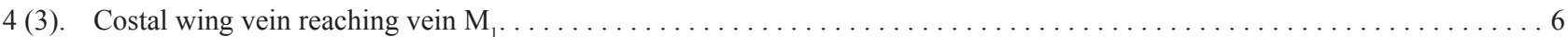
Costal wing vein ending at vein $\mathrm{R}_{4+5}$. Palearctic $\ldots \ldots \ldots \ldots \ldots \ldots \ldots \ldots \ldots \ldots$ Lipoleucopis Meijere ...5

5 (4). Scutum densely setulose; with three pairs of dorsocentral setae; prescutellar acrostichal seta present. Surstylus beak-shaped,

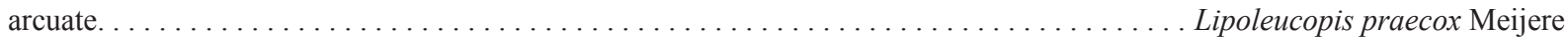
Scutum with very sparse setulae; with one pair of dorsocentral setae; prescutellar acrostichal seta absent. Surstylus hammershaped, with broad basiphallus tapering to sharpened tip . ...................... Lipoleucopis pulchra Raspi]

6 (4). Small, $2 \mathrm{~mm}$ or less in length. Ocellar seta present, reclinate. Upper part of fronto-orbital area with 1 or 2 enlarged, lateroclinate setulae. Palearctic (in part) $\ldots \ldots \ldots \ldots \ldots \ldots \ldots \ldots \ldots \ldots \ldots \ldots \ldots \ldots \ldots \ldots \ldots \ldots$ Malloch, in part...8

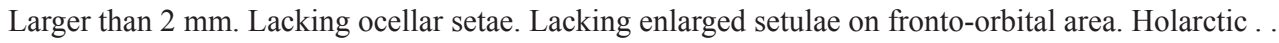

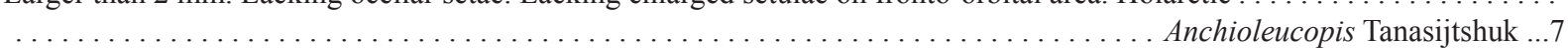


7 (6). Frons pale grey with dark elongate triangle of ocellar plate reaching lunule. Legs black with femora yellow at apex. In male

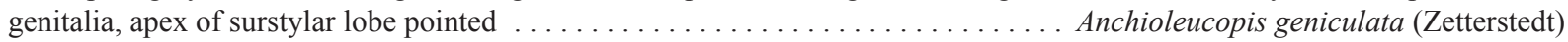
Frons pale grey with greyish ocellar plate visible only in dorsal view. Legs black except tibiae with yellow bases and apices, and basotarsomere yellow. In male genitalia, apex of surstylar lobe rounded........Anchioleucopis macalpinei Tanasijtshuk

8 (6). Ocellar seta small, 1/3 length of inner vertical seta. Fore tarsus yellow. In male, phallus strongly recurved in lateral view, with large ventral lobe with toothed distal edge. In female, sternite 7 divided medially by membranous strip . . . . . . . . . .

. [Neoleucopis orbiseta (McAlpine)] Ocellar seta large, subequal in length to inner vertical seta. Fore tarsus brown. In male, phallus simple, comma-shaped in lateral view. In female, sternite 7 entire $\ldots \ldots \ldots \ldots \ldots \ldots \ldots \ldots \ldots \ldots \ldots \ldots \ldots \ldots \ldots \ldots \ldots \ldots \ldots \ldots \ldots \ldots$ Neoleucopis freyi (McAlpine)

9 (3). Body and head shiny black. Frons with 1 strong fronto-orbital seta present. Crossvein bm-cu stub-like, incomplete, not fully separating cells $\mathrm{dm}$ and $\mathrm{bm}$. Neotropical (predators of Ortheziidae) .........................elacopis Sabrosky) Body and head predominantly pruinose, at most with abdomen shiny black. Fronto-orbital setae absent, or with more than 1.

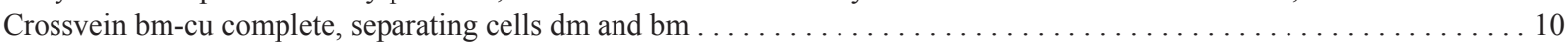

10 (9). Anepisternum with 1 to several setae, setulae, or both, along posterior edge. Afrotropical, Neotropical (predators of

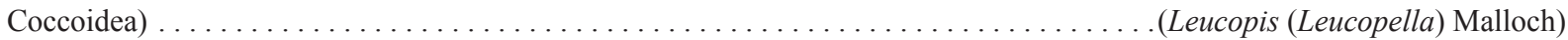

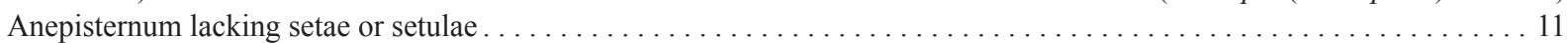

11 (10). Frons lacking strong fronto-orbital setae, although slightly enlarged setulae may be present in upper part. Ocellar setae absent,

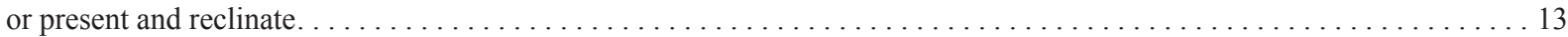
Frons with 2 or more strong fronto-orbital setae. Ocellar setae small, proclinate and diverging $\ldots \ldots \ldots \ldots \ldots 12$

12 (11). Frons with 2 fronto-orbital setae present, with anterior seta equidistant between posterior seta and lunule. Prescutellar acrostichal seta present. Abdominal tergites shiny black. Neotropical (predators of Ceroplastes Gray scales) ..................

(Chamaeleucopis Gaimari) Frons with series of 5 or 6 evenly spaced, strong fronto-orbital setae. Prescutellar acrostichal seta absent. Abdominal tergites silvery-grey pruinose with darkened pruinose spots on tergite 3. Nearctic ............ [Chamaethrix necopina Gaimari]

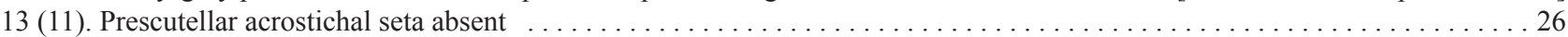

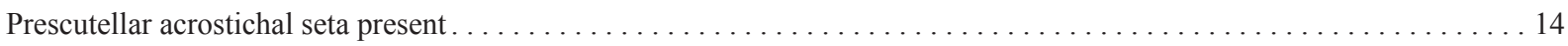

14 (13). Body and head silvery-grey pruinose; scutum with dorsocentral vittae; abdomen with paired dark spots on tergite 3. Ocellar seta absent. Holarctic (predators of eggs within coccoid ovisacs) . ................. (Leucopomyia Malloch) Body and head dull, dark grey to brown pruinose; scutum lacking dorsocentral vittae; abdomen lacking paired spots on tergite 3. Ocellar seta present. Holarctic, Neotropical . . . . . . . . . . . . . . . . Neoleucopis Malloch, in part ... 15

15 (14). Ocellar seta weak, shorter than distance from anterior ocellus to vertex, frequently pale and very fine $\ldots \ldots \ldots \ldots \ldots$ Ocellar seta strong, as long or longer than distance from anterior ocellus to vertex, black. . . . . . . . . . . . .

16 (15). Antennal pedicel light brown, distinctly paler than first flagellomere. In lateral view of male genitalia, epandrium large, with 10 or more setae on dorsal surface; phallus sickle-shaped ............... Neoleucopis hadzibeiliae (Tanasijtshuk) Antennal pedicel concolorous with first flagellomere, silvery grey at some angles. In lateral view of male genitalia, epandrium large or narrow, with fewer than 8 setae on dorsal surface; phallus not sickle-shaped $\ldots \ldots \ldots \ldots \ldots \ldots \ldots \ldots \ldots$

17 (16). Setulae on the frontal plate and along the eye margin weak and pale. Ocellar triangle sparsely and weakly setulose. In lateral view of male genitalia, epandrium large with convex dorsum, with surstylar lobe narrow; phallus widest at middle. In female,

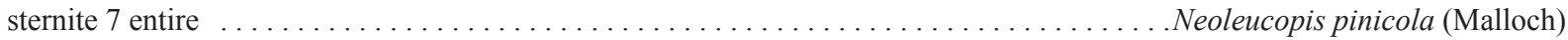
Setulae on the frontal plate and along the eye margin coarse and black. Ocellar triangle densely and strongly setulose. In lateral view of male genitalia, epandrium narrow, smoothly tapering through surstylar lobes; phallus widest basally. In female, sternite

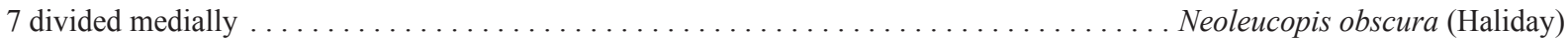

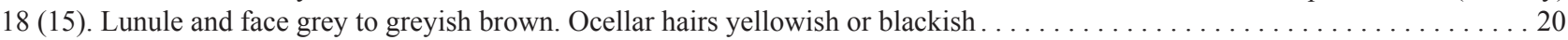

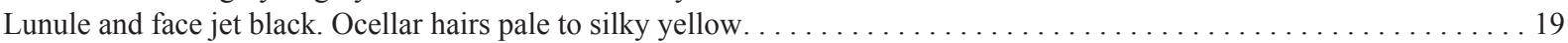

19 (18). Ocellar hairs distinctly longer and stronger than adjacent hairs. Posterior ocelli farther apart than distance to anterior ocellus. Prescutellar acrostichal seta easily distinguished from surrounding setulae .............. Neoleucopis militia (McAlpine) Ocellar hairs scarcely distinguishable from adjacent hairs. Distance from anterior ocellus to a posterior ocellus greater than distance between posterior ocelli. Prescutellar acrostichal seta usually indistinguishable from surrounding setulae ........

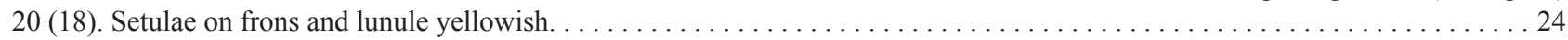

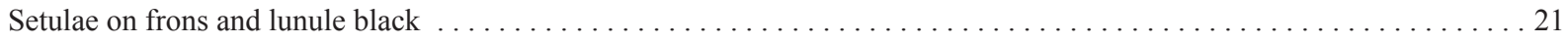

21 (20). In male, sternites 4 and 5 each with paired dense patches of thick, medially-oriented setulae; epandrium in lateral view large, extending through thick surstylar lobes; phallus with extremely enlarged basal lobe, constricted relative to long thin distiphallus. In female, medial third of tergite 6 lacking pruinosity and only lightly sclerotized; tergite 7 with distinct jet-black longitudinal striations; tergite 8 deeply cleft anteriorly; sternite 7 medially separated into two halves . . .

Neoleucopis kartliana (Tanasijtshuk) In male, sternites 4 and 5 with normal setulae, neither dense, thick, in patches, nor medially oriented; epandrium with surstylar lobe distinctly tapering; phallus variable, but basal lobe neither massive nor constricted relative to distiphallus; distiphallus not long and thin. In female, tergite 6 pruinose and sclerotized throughout; tergite 7 grey to brown pruinose, lacking longitudinal

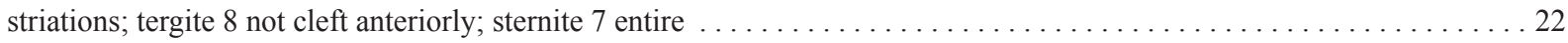

22 (21). Ocellar setae subequal to or slightly longer than adjacent setulae. Fronto-orbital area with 1 or more slightly enlarged setulae in upper part. Distiphallus abruptly tapered. Spermathecae small and spherical . . . . . . . Neoleucopis atratula (Ratzeburg) Ocellar setae at least $2 \mathrm{X}$ longer than adjacent setulae. Fronto-orbital area lacking enlarged setulae. Distiphallus variable,

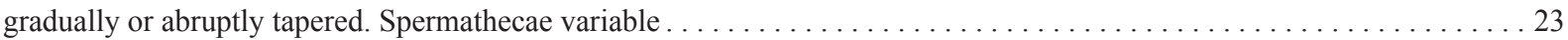


23 (22). Basal two segments of fore tarsus and basal three segments of mid and hind tarsi yellow. Epandrium conical in lateral view. Basiphallus moderately swollen, with distiphallus gradually tapered. Spermathecae small and spherical . ............

Neoleucopis ancilla (McAlpine), in part Basal segment of fore tarsus and basal two segments of mid and hind tarsi yellow. Epandrium parallel-sided. Basiphallus strongly swollen, with distiphallus abruptly tapered. Spermathecae large and ovoid ....... Neoleucopis tapiae (Blanchard)

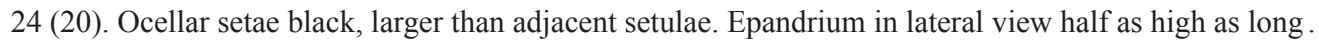

Neoleucopis ancilla (McAlpine), in part Ocellar setae weak and pale, scarcely distinguishable from adjacent setulae. Epandrium in lateral view up to $1 / 3$ as high as

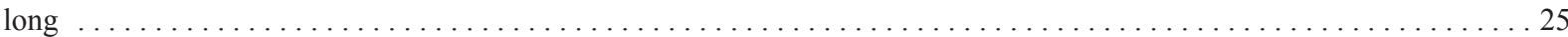

25 (24). Setulae of frons along eye margin long and erect (length subequal to distance between posterior ocelli). Central part of scutum brownish. Epandrium in lateral view with dorsal edge relatively straight. ............ Neoleucopis manii (Tanasijtshuk) Setulae of frons along eye margin short and depressed forward (length less than half distance between posterior ocelli). Scutum uniformly silvery grey. Epandrium in lateral view with dorsal edge rounded........... Neoleucopis aciliosa (McAlpine)

26 (13). Ocellar setae absent in both sexes, and ocellar triangle neither densely pilose nor fuzzy in males, but if moderately fuzzy (i.e., not completely and uniformly covering the area), then posterior ocelli equidistant in comparison with distance from one

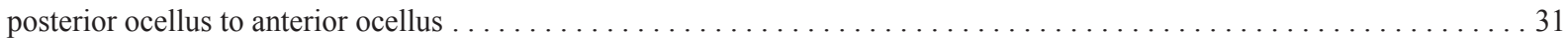
Ocellar setae small and reclinate, or ocellar triangle (in males) densely and uniformly pilose and fuzzy with posterior ocelli

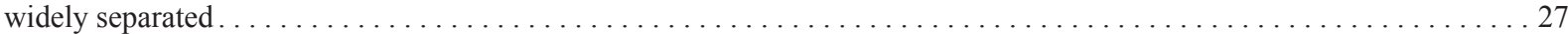

27 (26). Fronto-orbital area lacking enlarged setulae. Ocellar plate greatly expanded, with posterior ocelli widely spread, much farther apart than distance between anterior and one posterior ocellus. Ocellar seta present in females, but usually absent in males that instead have ocellar plate densely pilose and fuzzy. Nearctic, Neotropical..................... (Leucopina Malloch) Fronto-orbital area with 1 or 2 (rarely 0 or 3) enlarged setulae dorsally. Ocellar plate not expanded, pilose nor densely fuzzy, but posterior ocelli sometimes slightly farther apart than distance to anterior ocellus. Ocellar seta present or absent . . . . 28

28 (27). Head high, height to length ratio nearly 2:1. Eye height to length ratio 2:1. Lunule subequal in height to length to frons, with conspicuous proclinate black setulae. Ocellar seta absent. Anterior ocellus surrounded by ring of short black setulae. Neotropical (predators of eggs within coccoid ovisac) . . . . . . . . . . (Echinoleucopis Gaimari \& Tanasijtshuk) Neither head, eye nor lunule so high. Lunule with small setulae inconspicuous. Ocellar seta present. Anterior ocellus lacking

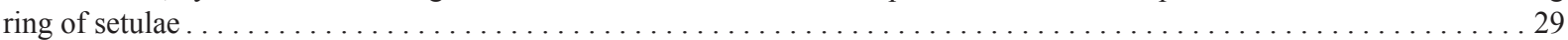

29 (28). Lunule with numerous erect black setulae. Scutum and scutellum dark brown pruinose. Legs entirely jet black. . . . . . . . .

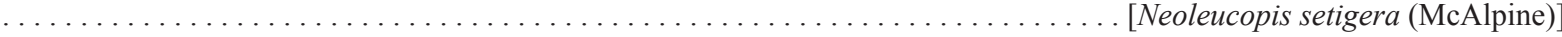
Lunule with small setulae inconspicuous. Scutum grey pruinose, with goldish dorsocentral vittae. Legs with tips of femora, bases of tibiae and at least basal two tarsomeres yellow. Nearctic, Neotropical (feed on Coccoidea); Palearctic ..........

.................................................. Leucopis (Xenoleucopis) Malloch ...30

30 (29). Dorsocentral vitta with diffuse edges, blending into goldish shade over posterior part of scutum and scutellum. Eye 4 X higher than gena. Distal section of vein $\mathrm{CuA}_{1} 2 \mathrm{X}$ longer than length of crossvein dm-cu . . .

[Leucopis (Xenoleucopis) setifrons Tanasijtshuk] Dorsocentral vitta sharply outlined, continuing through grey scutum. Scutellum grey. Eye at least $5 \mathrm{X}$ higher than gena. Distal section of vein $\mathrm{CuA}_{1}$ up to $1.5 \mathrm{X}$ longer than length of crossvein $\mathrm{dm}-\mathrm{cu}$....... Leucopis (Xenoleucopis) raoi Tanasijtshuk

31 (26). Abdomen silvery-grey to grey pruinose, often with spots on tergite 3 . Frons not protruding over lunule, lacking stiff lateroclinate setulae, and lacking enlarged laterally directed setulae in anterolateral corners. Maxillary palpus normal, much smaller than

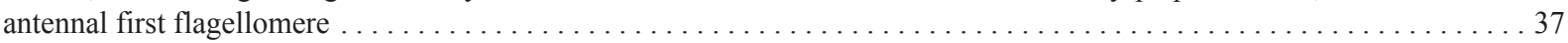
Abdomen shiny black with only sparse pruinosity. Frons with 1 or 2 rows of stiff black lateroclinate setulae along eye margin. In male, frons protruding roof-like over lunule, and with enlarged laterally directed setulae in anterolateral corners (sometimes clumped into horn-like pencils). In female, maxillary palpus greatly enlarged (subequal to antennal first flagellomere) and

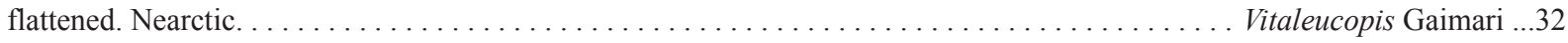

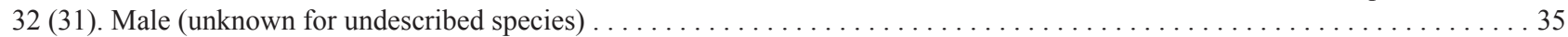

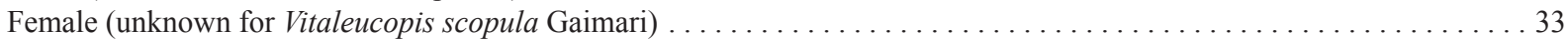

33 (32). Upper face (between antennal sockets) silvery pruinose; antenna light brown, except basal part orange; palpus orange, with distal part light brown; scutum and scutellum bronzy pruinose, distinctly differentiated from silvery-grey pruinose pleuron ..

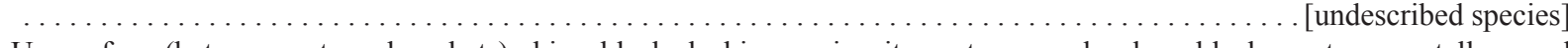
Upper face (between antennal sockets) shiny black, lacking pruinosity; antenna and palpus black; scutum, scutellum and

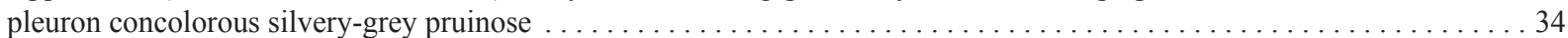

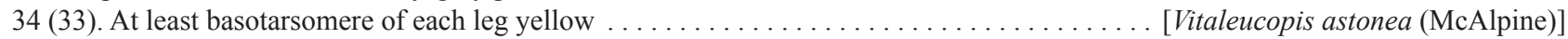
Tarsi entirely dark brown (hind basotarsomere sometimes dark orange basally) ............ Vitaleucopis nidolkah Gaimari

35 (32). Anterolateral part of frons with cluster of 2-4 lateroclinate setae, whisker-like (not clustered to appear as 1 very thick seta), with length less than length of inner vertical seta . . . . . . . . . . . . . . . Vitaleucopis nidolkah Gaimari Anterolateral corner of frons with distinct tight cluster of 4 or 5 lateroclinate setae (appearing like 1 very thick seta), with length

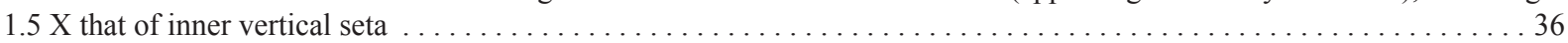

36 (35). Frons with width and length subequal; distance from vertex to anterior tip of frons $1.7 \mathrm{X}$ width of frons at level of anterior

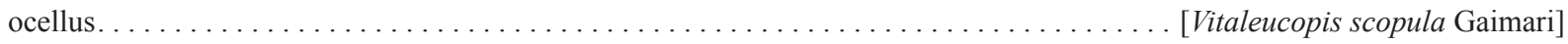
Frons $1.4 \mathrm{X}$ wider than long; distance from vertex to anterior tip of frons $1.3 \mathrm{X}$ width of frons at level of anterior ocellus ...

. [Vitaleucopis astonea (McAlpine)]

37 (31). Scutum with dorsocentral vittae (rarely absent) and pair of anterior median vittae. Frons gently curved and sloping through lunule. Plane of face and parafacial at obtuse angle with frons. Cosmopolitan. . . . . . . . . . Leucopis Meigen, in part ...44 
Scutum unicolorous grey, lacking vittae. Frons flat, sometimes slightly concave medially, ending at $90^{\circ}$ angle with upper edge of lunule. Plane of face and parafacial are at an acute angle with the frons. Holarctic . . . . . . . Leucotaraxis gen. nov.... 38

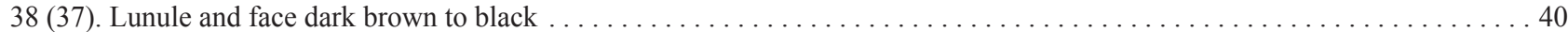

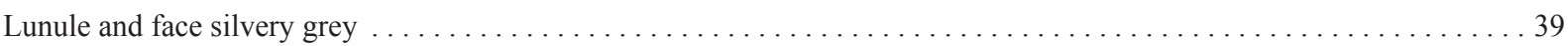

39 (38). Postpronotum with 1 to several long setulae (longer than setulae on scutum) medially from postpronotal seta. In male, phallus from lateral view with broad wedge-shaped anterobasal process at $90^{\circ}$ angle from thin elongate pointed process. In female, tergite 7 present and strap-like, and sternite 7 present and arcuate . . . . . . . . . Leucotaraxis argenticollis (Zetterstedt) Postpronotum lacking setulae, or with only tiny setulae (much smaller than setulae on scutum) medially from postpronotal seta. In male, phallus from lateral view elongate and thin, curving gently to pointed tip. In female, tergite and sternite 7 absent $\ldots$

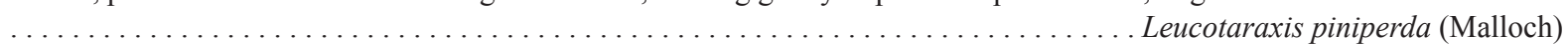

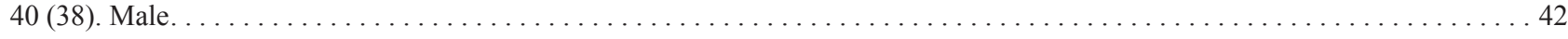

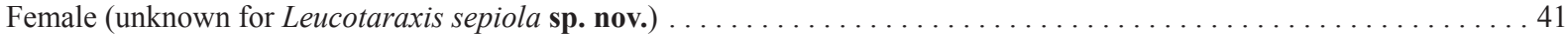

41 (40). Tergite 7 absent . . . . . . . . . . . . . . . . . . . . . . . . . . Leucotaraxis piniperda (Malloch) Tergite 7 present and strap-like $\ldots \ldots \ldots \ldots \ldots \ldots \ldots \ldots \ldots \ldots \ldots \ldots \ldots \ldots \ldots \ldots \ldots \ldots \ldots \ldots \ldots \ldots$. $\ldots \ldots \ldots$ atrifacies (Aldrich)

42 (40). Epandrial complex large and polished black, with epandrium extending into central process bearing cerci at upward angle.

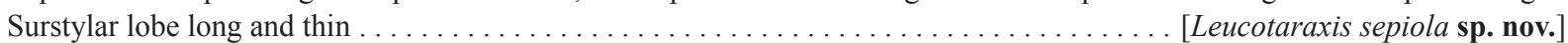
Epandrial complex simple, small, yellowish- to silvery-grey pruinose, with no central epandrial process. Surstylar lobe short,

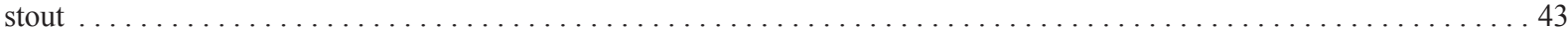

43 (42). Phallus in lateral view very long and thin, more than $10 \mathrm{X}$ longer than height at middle, gently curved throughout to pointed

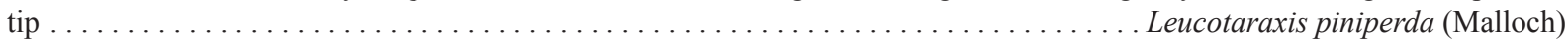
Phallus in lateral view long and thick, less than $8 \mathrm{X}$ longer than height at middle, straight-sided until abrupt curve to pointed

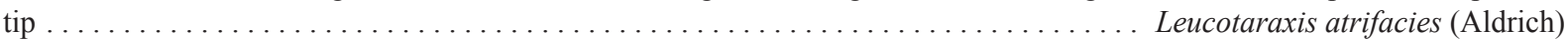

44 (37). Frons with surface covered with long, thin, reclinate silvery setulae. In male, phallus with two prominent, curved, tusk-like

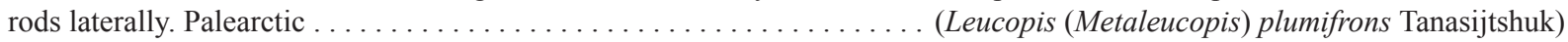
Frons lacking thin, reclinate silvery setulae. In male, phallus simple, lacking lateral rods. Cosmopolitan. ....

Leucopis (Leucopis) Meigen ...... 45

45 (44). Scutum reddish brown to brown, lacking dorsocentral vittae or very faintly visible. Gena less than $1 / 5$ eye height. Tibiae and tarsi yellow. In male, abdominal tergite 3 brownish grey without spots; phallus awl-shaped, smoothly curved ..........

Leucopis (Leucopis) adelgivora Tanasijtshuk Scutum silvery grey to greyish brown, with distinct dorsocentral vittae, which may be faint. Gena more than $1 / 5$ eye height. Tibiae and tarsi predominantly dark brown. In male, tergite 3 either brownish or silvery grey with paired spots; phallus variable,

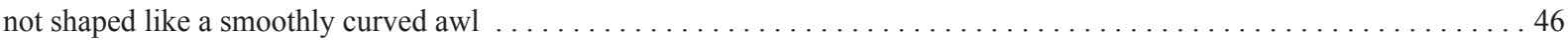

46 (45). Body greyish brown, with dark goldish-brown dorsocentral vittae that diffuse together in posterior part of scutum. Gena high, about $1 / 2$ eye height. Scutellum goldish brown. Abdomen uniformly brown .... . Leucopis (Leucopis) hennigrata McAlpine Body light grey to silvery grey. Gena $1 / 4-1 / 3$ eye height. Dorsocentral vittae variable, but never diffusing together in posterior part of scutum. Scutellum silvery grey. Abdomen with tergites 3-5 silvery grey, with paired dark spots on tergite 3 (except for

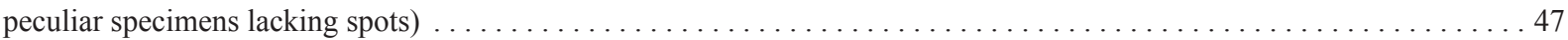

47 (46). Ocellar plate with patch of short stiff setae lateral to anterior ocellus. Abdominal tergites covered with long strong setae (mostly half length of tergite). In male, phallus narrow in lateral view ........... [Leucopis (Leucopis) spinifrons Tanasijtshuk] Ocellar plate lacking short stiff setae lateral of anterior ocellus, instead bare to slightly fuzzy. Abdominal tergites with normal setae (much shorter than half length of tergite). Phallus variable (only males key from here) . . . . . . . . . . . 4 48

48 (47). Surstylar lobe broad, extended from narrow epandrium, parallel-sided all the way to large blunt tip from lateral view ......

Leucopis (Leucopis) aphidiperda Rondani Surstylar lobe extended from convex epandrium, tapering to narrow or sharpened tip. . . . . . . . . . . . . 49

49 (48). Surstylar lobe beak-like, with a wide base and tapering to tip. Phallus either with very strong, angular, subbasal ventral

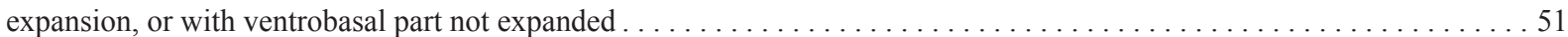
Surstylar lobe narrow from base to tip. Phallus with subbasal ventral expansion small, smoothly rounded $\ldots \ldots \ldots \ldots 50$

50 (49). Dorsocentral vittae varying from olive brown to pale goldish brown, with dark grey median vittae. Distiphallus from lateral view slightly curved to blunt (sometimes slightly dilated) tip . . . . . . . . . . Leucopis (Leucopis) ninae Tanasijtshuk Dorsocentral vittae grey, concolorous with median vittae. Distiphallus from lateral view straight and narrow to sharpened tip

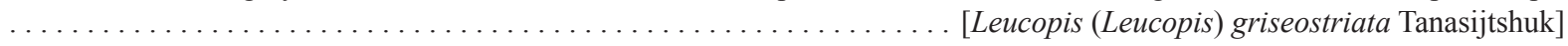

51 (49). Phallus with strongly produced, angular subbasal ventral expansion. . . . . . Leucopis (Leucopis) cinarophaga Tanasijtshuk Phallus narrow throughout in lateral view .................... Leucopis (Leucopis) glyphinivora Tanasijtshuk

52 (1). Scutum with 4 or more pairs of postsutural dorsocentral setae, shortening anteriorly. Wing hyaline. Anepisternum with several fine hair-like setulae in anterodorsal corner. Anepimeron bare. Calypter entirely white ... . [Cremifania nearctica McAlpine] Scutum with 1 or 2 pairs of dorsocentral setae. Wing with dark markings at least in subcostal cell and/or costal cell, or wing more extensively patterned. Anepisternum bare in anterodorsal corner. Anepimeron with or without a setula medioventrally.

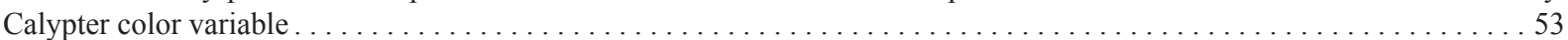

53 (52). Antennal arista lanceolate, with 3rd segment flattened, broadened and pointed apically. Costal cell with a central diffuse dark spot; subcostal cell with large black spot apically and a small subbasal spot confluent with dark spot in costal cell. Scutum with 1 pair of dorsocentral setae. Anepimeron lacking medioventral setula. Calypter and fringe entirely whitish yellow. .......

[Cremifania lanceolata Papp] Antennal arista normal, or only basal part thickened. Costal cell hyaline; subcostal cell entirely darkened. Scutum with 2 pairs

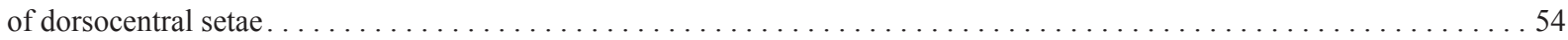


54 (53). Ocellar triangle small, with grey pruinosity only surrounding ocelli. Lacking interfrontal setae. Wing membrane not patterned outside of subcostal cell. Anepimeron with 1 or more setulae medioventrally. Calypter with margin and fringe dusky .......

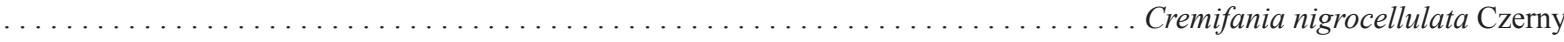
Ocellar triangle elongated, with grey pruinosity extending anteriorly nearly to lunule. Anterior tip of ocellar triangle with a pair of strong, proclinate interfrontal setae. Wing membrane darkened at least around distal part of vein $\mathrm{R}_{2+3}$ and surrounding crossvein dm-cu. Anepimeron bare. Calypter with margin and fringe pale ............. [Cremifania bulgarica Papp]

\section{Annotated list of species of Chamaemyiidae feeding on Pinaceae-infesting Sternorrhyncha}

Anchioleucopis Tanasijtshuk, 1997: 115 (Fig. 7)

Anchioleucopis geniculata (Zetterstedt, 1855: 4810; Leucopis)

Type locality: Sweden (HT + , MZLU).

This species occurs in northern Europe, and although it has not been reared, it is very likely a predator of adelgids, and has been collected from canopies of Scots pine, Pinus sylvestris (Thunes et al. 2004) and swept from the same species infested with Pineus pini (McLean 1982).
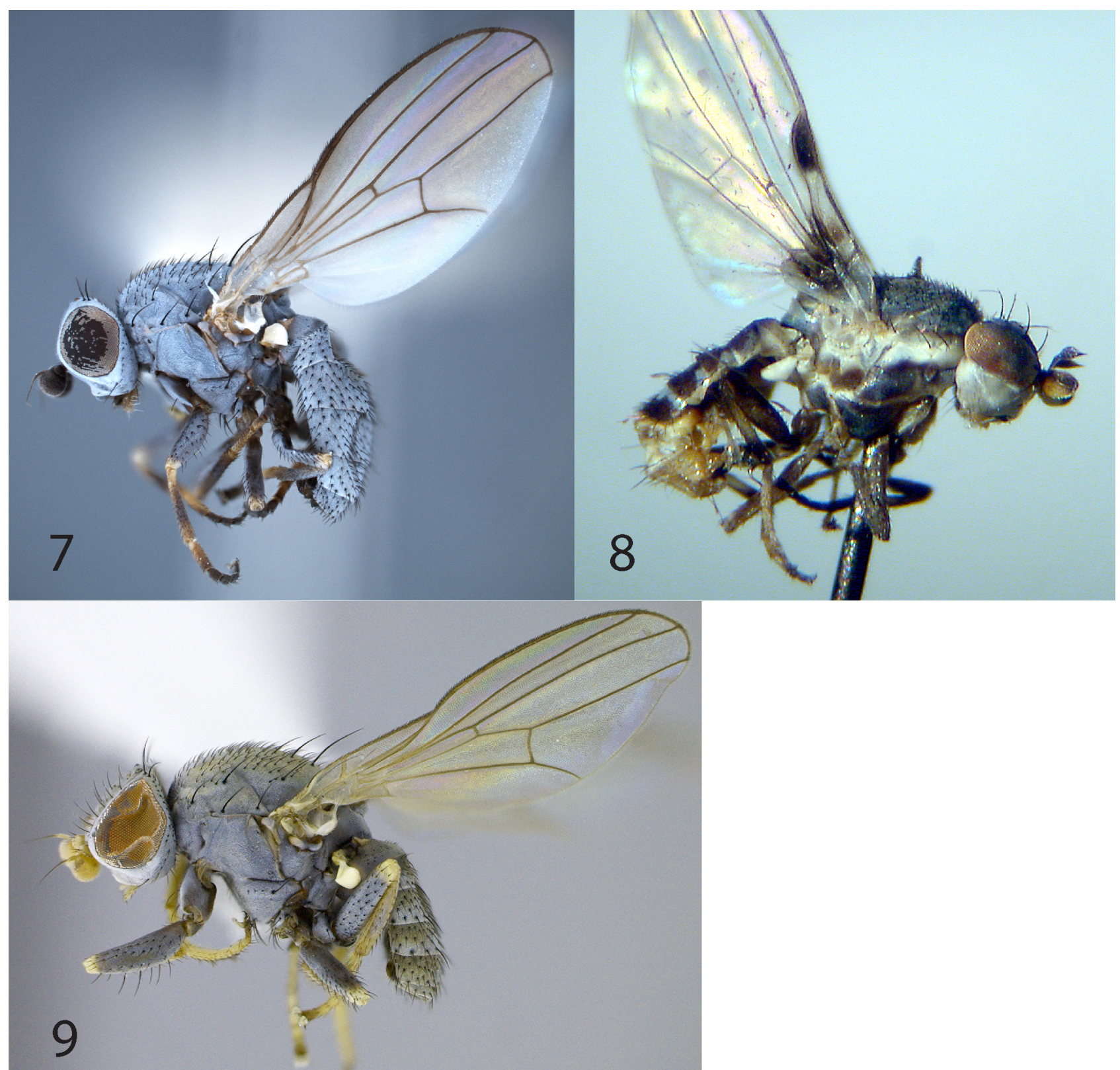

FIGURES 7-9. Chamaemyiidae genera, lateral habitus. 7. Anchioleucopis geniculata (Zetterstedt), female. 8. Cremifania lanceolata Papp, holotype male. 9. Chamaethrix necopina Gaimari, holotype male. 
Anchioleucopis macalpinei Tanasijtshuk, 2001: 904

Type locality: USA: Ohio (HT $\hat{\partial}, \mathrm{CNC}$ ).

This species occurs in eastern North America, and has been reared only from Pineus strobi, which most commonly infests eastern white pine, Pinus strobus.

Chamaethrix Gaimari, 2020: 62 (Fig. 9)

[Chamaethrix necopina Gaimari, 2020: 62]

Type locality: USA: Arizona (HT $\hat{\sigma}$, CSCA).

This species occurs in the southwestern United States in areas above $2100 \mathrm{~m}$ elevation. All known specimens were swept from infestations of Cinara ponderosae in young stands of Pinus ponderosa, but despite rearing $>150$ chamaemyiid larvae from this host by the first author, none were this species. It remains a possibility that this species is a predator in that system.

Cremifania Czerny, 1904: 169 (Fig. 8)

[Cremifania bulgarica Papp, 2010: 195]

Type locality: Bulgaria (HT §े, HNHM).

This species is known only from Bulgaria, collected at an elevation of $2250 \mathrm{~m}$ in a Pinaceae-dominated habitat. Although never reared, it is likely a predator of adelgids.

[Cremifania lanceolata Papp, 1994: 105]

Type locality: Hungary (HT $\curvearrowright$, HNHM).

This species is known only from Hungary, originally collected in an oak forest with Pinaceae present within about $1 \mathrm{~km}$. Although never reared, it is likely a predator of adelgids.

[Cremifania nearctica McAlpine, 1963: 252]

Type locality: USA: New Mexico (HT ô, USNM).

This species is known only from the southwestern United States, and was collected at higher elevations in an area dominated by Pinaceae. Although never reared, it is likely a predator of adelgids.

Cremifania nigrocellulata Czerny, 1904: 170

Type locality: Austria (HT 9 , NHMW).

This species is native to central Europe and was introduced and established in both eastern and western North America (Harris \& Dawson 1979, Humble 1994). Much attention was paid to this species in the 1950s due to extensive biological control efforts against balsam woolly adelgid, Adelges piceae, attacking several species of fir, Abies spp., in North America.

Leucopis (Leucopis) Meigen, 1830: 133 (Fig. 10)

Leucopis (Leucopis) adelgivora Tanasijtshuk, 1986: 204

Type locality: Russia: Sakhalin (HT Ô, ZISP).

Known only from the Russian Far East (Sakhalin), this species is reported as a predator of Adelges japonicus (Monzen) on Ayan fir, Abies ajanensis (Tanasijtshuk 1986), but A. japonicus feeds on Larix and Picea (Sano et al. 2008), so the specific prey is unclear.

Leucopis (Leucopis) aphidiperda Rondani, 1848: 435

Type locality: Italy: Parma (LT $\hat{\jmath}$, MZUB).

This is a widespread species, found in southern and eastern Europe, the eastern Palearctic and the Near East. It is known mainly as a predator of aphids on angiosperms, but has been reared from a species of Cinara on Abies (Tanasijtshuk 1986). 
Leucopis (Leucopis) cinarophaga Tanasijtshuk, 1962: 225

Type locality: Russia: Leningrad region (HT $\hat{\partial}$, ZISP).

This species is found mainly in northern Europe, although it has also been found in southern Europe. As the name implies, it is a predator of Cinara species. Specifically, it has been reared from Cinara brauna Böner on Pinus laricio, Cinara pini (L.) and Cinara pinea (Mordvilko) on Pinus sylvestris, and on Cinara costata (Zetterstedt) and Cinara pruinosa (Hartig) on Picea excelsa (Tanasijtshuk 1986).

Leucopis (Leucopis) glyphinivora Tanasijtshuk, 1958: 92

Type locality: Russia: Leningrad region (HT $\hat{\partial}$, ZISP).

This is a very widespread species throughout Europe, the eastern Palearctic, the Near East, North America and in South Africa and the Oriental Region. Some of this distribution may be due to introductions, and this species has been considered as a possible biocontrol agent against pest aphids (Barriault et al. 2018). This is a polyphagous species, being known to attack more than 70 species of aphids on more than 100 species of plants (Tanasijtshuk 1986). Among these records is a species of Cinara infesting Pinus sylvestris.

[Leucopis (Leucopis) griseostriata Tanasijtshuk, 2006: 282]

Type locality: USA: New Hampshire (HT ô, USNM).

This species is known only from the eastern United States. Although it was never reared, it is thought to be a predator of adelgids because it had identical collection labels as a series of specimens belonging to Neoleucopis pinicola and Leucotaraxis argenticollis.

Leucopis (Leucopis) hennigrata McAlpine, 1978: 350

Type locality: Germany (HT $\widehat{\partial}$, CNC).

This species is known from central and southern Europe, and was introduced into eastern and western Canada as a biological control agent against balsam woolly adelgid, Adelges piceae on several species of fir, Abies spp. This species has a rather wide adelgid host range, including: Adelges piceae and Adelges nordmannianae (Eckstein) infesting several species of fir, as well as Adelges (Sacchiphantes) viridis (Ratzeburg) infesting larch, Larix spp.

Leucopis (Leucopis) ninae Tanasijtshuk, 1966: 234

Type locality: Kazakhstan (HT §̂, ZISP).

This is a very widespread species, occurring in central and southern Europe, the eastern Palearctic, Near East, and north Africa, and has been introduced into the Nearctic and Afrotropical Regions. It is polyphagous, known to feed on more than 50 species of Sternorrhyncha, particularly aphids, but also has been reared from Pineus pini infesting Pinus sylvestris, as well as some Coccoidea (Tanasijtshuk 1986).

[Leucopis (Leucopis) spinifrons Tanasijtshuk, 2006: 284]

Type locality: Canada: Manitoba (HT ô, CNC).

This species is known from south-central Canada. It is thought to be a predator of adelgids because it was collected by sweeping white spruce, Picea glauca.

Leucopis (Xenoleucopis) Malloch, 1933: 384 (Fig. 11)

Leucopis (Xenoleucopis) raoi Tanasijtshuk, 1986: 182

Type locality: India: Himachal Pradesh (HT $\stackrel{\jmath}{\text {, ICPR) }}$

This species is known only from India, and has been reported in the Himalayas as an important predator of Adelges knucheli on Morinda spruce, Picea smithiana, and on silver fir, Abies pindrow (Krishnaswamy \& Chacko 1988).

[Leucopis (Xenoleucopis) setifrons Tanasijtshuk, 1986: 181]

Type locality: Kyrgyzstan (HT ô, ZISP).

Known only from Kyrgystan, this species is assumed to be a predator of adelgids due to having been swept from Tien-Shan fir, Abies sibirica var. semenovii. 

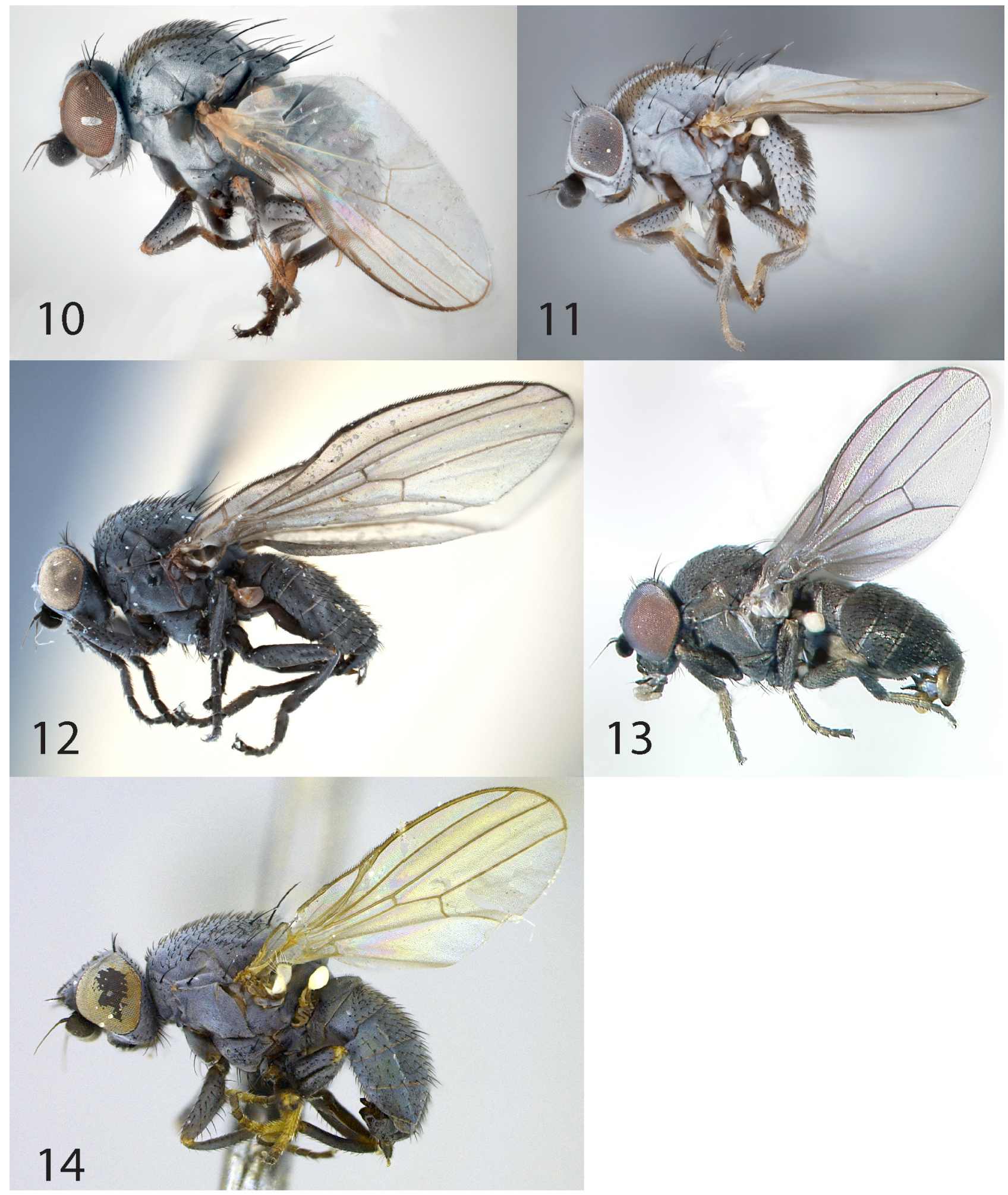

FIGURES 10-14. Chamaemyiidae, genera and subgenera, lateral habitus. 10. Leucopis (Leucopis) sp., male. 11. Leucopis (Xenoleucopis) cilifemur Malloch, male. 12. Lipoleucopis praecox Meijere, male. 13. Neoleucopis kartliana (Tanasijtshuk), male. 14. Vitaleucopis astonea (McAlpine), holotype male. 
Leucotaraxis gen. nov. (Figs 1-5)

Leucotaraxis argenticollis (Zetterstedt, 1848: 2814; Leucopis), comb. nov.

Type locality: Sweden (LT $\widehat{\partial}$, MZLU).

This species is widespread in North America, and occurs in northern Europe, the far eastern Palearctic, and India. They are predators of species of Adelges and Pineus infesting Abies, Picea, Pinus, and Tsuga (details provided above). They have also been swept from Cinara ponderosae infesting young stands of Pinus ponderosa.

Leucotaraxis atrifacies (Aldrich, 1925: 152; Leucopis), comb. nov.

Type locality: USA: California (HT + , USNM).

This species is known only from western North America, attacking species of Adelges and Pineus infesting Tsuga and Pinus (details provided above). They have also been swept from Cinara ponderosae infesting young stands of Pinus ponderosa.

Leucotaraxis piniperda (Malloch, 1921: 351; Leucopis), comb. nov.

Type locality: USA: Illinois (HT $q$, INHS).

This species is widespread in both eastern and western North America, attacking species of Adelges and Pineus infesting Abies, Picea, Pinus, and Tsuga (details provided above).

\section{[Leucotaraxis sepiola $\mathbf{s p .}$ nov.]}

Type locality: USA: New Mexico (HT $\hat{\partial}$, CSCA).

This species is known only from the southwestern United States. Although never reared, it has been swept from Cinara ponderosae infesting young stands of Pinus ponderosa, which may have also been infested with adelgids.

Lipoleucopis Meijere, 1928: 76 (Fig. 12)

Lipoleucopis praecox Meijere, 1928: 76

Type locality: Netherlands (2ST $\hat{~}, 2 \mathrm{ST}+$, $1 \mathrm{ST}$ sex?, ZMAN).

This species is native to northern Europe, and is a predator of Pineus pini on Pinus sylvestris.

[Lipoleucopis pulchra Raspi, 2008: 664]

Type locality: United Arab Emirates (HT $\hat{o}$, DCDS).

This species is known only from the Arabian Peninsula and Morocco (Ebejer 2016), and has never been reared. The lack of native Pinaceae would suggest a different host than adelgids if Lipoleucopis pulchra is native to the $\mathrm{UAE}$ or Morocco, but the possibility remains that the species is more widespread, and feeds on adelgids infesting ornamental Pinaceae in its currently known range.

Neoleucopis Malloch, 1921: 357 (Fig. 13)

Neoleucopis aciliosa (McAlpine, 1971: 1871; Leucopis)

Type locality: Japan (HT $\hat{\jmath}$, CNC).

This species is known only from Japan, and has been reared from species of Pineus infesting Pinus pentaphylla and Pinus koraiensis.

Neoleucopis ancilla (McAlpine, 1971: 1869; Leucopis)

Type locality: USA: Oregon (HT ${ }^{\lambda}$, USNM).

This species is known from western North America, as predators of species of Pineus.

Neoleucopis atratula (Ratzeburg, 1844: 170; Musca)

Type locality: Germany (NT $\curvearrowright$, CNC). 
This species is widespread in Europe, the Near East, and the eastern Palearctic, and has been introduced into Australia and New Zealand, Argentina, and in several parts of North America. This species was among the predators introduced and established for biological control of Adelges piceae attacking true firs, Abies spp., in North America (Humble 1994). Rearing indicates that Adelges piceae is a primary host for this species. In addition, it is known as a predator of species of Pineus (such as Pineus strobi) infesting species of Pinus, and of other species of Adelges infesting species of Abies. The species has been collected from canopies of Scots pine, Pinus sylvestris (Thunes et al. 2004).

Neoleucopis freyi (McAlpine, 1971: 1869; Leucopis)

Type locality: Switzerland (HT ðे, CNC).

This species is known only from northern Europe, as predators of Adelges (Sacchiphantes) viridis on Japanese larch, Larix kaempferi.

Neoleucopis hadzibeiliae (Tanasijtshuk, 1986: 173; Leucopis)

Type locality: Georgia (HT $\precsim$, ZISP).

This species is known from the Caucasus region, as a predator in ovisacs of Marchalina caucasica Hadzibeili (Margarodidae) infesting Nordmann fir, Abies nordmanniana, and Oriental spruce, Picea orientalis.

Neoleucopis kartliana (Tanasijtshuk, 1986: 175; Leucopis)

Type locality: Georgia (HT $\hat{\partial}$, ZISP).

This species is known from Georgia through Greece, and Italy. Gaimari et al. (2007) gave detailed life history information, having reared the species from the scale Marchalina hellenica (Gennadius) (Margarodidae) on Pinus halepensis. The species was subsequently introduced into Italy to combat this pest (Viggiani \& Mustica 2008). The species was also reared from a puparium found on Oriental spruce, Picea orientalis.

Neoleucopis manii (Tanasijtshuk, 1968: 6; Leucopis)

Type locality: India: Assam (HT ${ }^{7}$, ICPR).

This species is known only from Assam, India, as a predator of species of Pineus infesting Pinus insularis.

Neoleucopis militia (McAlpine, 1971: 1855; Leucopis)

Type locality: Pakistan (HT ${ }^{7}, \mathrm{CNC}$ ).

This species is known only from Pakistan, although it was released against Adelges piceae in western North America, where it is not known to have established. It is known as a predator of species of Adelges infesting Abies pindrow.

Neoleucopis nigraluna (McAlpine, 1971: 1857; Leucopis)

Type locality: India: Assam (HT $\hat{\partial}, \mathrm{CNC}$ ).

This species is native to India and Pakistan and has been introduced into Hawaii and eastern North America. The species has been reared from species of Pineus infesting Pinus insularis (McAlpine 1971) and from Pineus simmondsi Yaseen \& Ghani (Greathead 1995). This species was released and established against Adelges piceae in North America, and against a Pineus species attacking Pinus pinaster in Hawaii.

Neoleucopis obscura (Haliday, 1833: 173; Leucopis)

Type locality: Ireland (LT ${ }^{\lambda}$, NMID).

This species is widespread in Europe, and has been introduced into Hawaii, and the eastern and western parts of North America. For Hawaii, although a small percentage of the vouchers from these releases are this species, most turned out to be $N$. tapiae. This species was also among the predators introduced and established for biological control of Adelges piceae attacking balsam fir, Abies balsamea, in North America. It is known to attack various species of Adelges infesting species of Abies, and less frequently species of Pineus infesting Pinus.

Leucopis olivacea Meijere 1928: 75, syn. nov. Type locality: Netherlands (LT $\hat{O}$, ZMAN). The following lectotype is designated here to stabilize the concept of the species, due to the importance of male characteristics to properly identify species in this genus: of specimen, double mounted on minuten into left pleuron, with the 
following labels: 1) "Diemen / 3.VIII.18 / deMeijere", 2) "ZMA040", 3) "Lectotypus $\widehat{\partial}$ / Leucopis / olivacea / de Meijere / des. Gaimari \& Havill". The paralectotype is female, with the same first label as the lectotype, and the following additional labels: 2) "L. olivacea / d.M. ”, 3) "ZMA041", 4) "Paralectotypus + / Leucopis / olivacea / de Meijere / des. Gaimari \& Havill”, 5) "Neoleucopis / obscura / (Haliday) / det. SD Gaimari, 2011".

[Neoleucopis orbiseta (McAlpine, 1971: 1862; Leucopis)]

Type locality: Finland (HT ô, CNC).

This species is known from northern Europe, and its biology is not known, but likely feeds on adelgids, following the same pattern as all other members of the genus found on Pinaceae.

Neoleucopis pinicola (Malloch, 1921: 357; Leucopis)

Type locality: USA: Illinois (HT $\widehat{\jmath}$, INHS).

This species is known from eastern North America and may be present in parts of Europe. It is known to prey on Pineus strobi infesting Pinus strobus, as well as Adelges piceae on balsam fir, Abies balsamea (McAlpine 1971, Sluss \& Foote 1973). The immature stages and biology were thoroughly described by Sluss \& Foote (1973), although the descriptions do not compare the species with congeners.

[Neoleucopis setigera (McAlpine, 1971: 1872; Leucopis)]

Type locality: Argentina: Tierra del Fuego (HT $\widehat{\partial}, \mathrm{CNC}$ ).

This species is only known from the type locality in Argentina, and nothing is known of its biology.

Neoleucopis tapiae (Blanchard, 1964: 137; Leucopis)

Type locality: Argentina: Nahuel Huapi (22 ST $\widehat{\jmath} / \%$, MACN).

Although described from Argentina, this was likely due to an early introduction with the planting of species of Pinus for lumber. This species is widespread in Europe and has been purposely introduced as a predator of species of Pineus infesting Pinus species in Hawaii, western North America, Malawi, South Africa and New Zealand (Greathead 1995). In Hawaii, this species was introduced under the name Neoleucopis obscura (along with the real N. obscura), only subsequently having been found to be this species (Greathead 1995). Specific rearing records include Pineus pini infesting Pinus radiata, Pineus strobi infesting Pinus strobus and Pinus sylvestris, Pineus cembrae (Cholodkovsky) infesting Pinus cembra, Pineus laevis (Maskell) infesting Pinus sylvestris and Pinus radiata, Pineus orientalis (Dreyfus) infesting a species of Pinus, Pineus boerneri infesting Pinus patula, Pineus havrylenkoi Blanchard infesting a species of Pinus.

Vitaleucopis Gaimari, 2020: 67 (Fig. 14)

[Vitaleucopis astonea (McAlpine, 1977: 14; Leucopis)]

Type locality: Canada: British Columbia (HT $\left.{ }^{\top}, \mathrm{CNC}\right)$.

This species is known only from western Canada. Although there is no rearing information, it was collected in a place characterized by Pinaceae, and can be assumed to be a predator of adelgids or Cinara aphids.

Vitaleucopis nidolkah Gaimari, 2020: 72

Type locality: USA: New Mexico (HT ô, CSCA).

This species is known only from the southwestern United States in areas above $2100 \mathrm{~m}$ elevation. The first author reared numerous individuals from field-collected larvae attacking Cinara ponderosae infesting Pinus ponderosa.

[Vitaleucopis scopulus Gaimari, 2020: 78]

Type locality: USA: California (HT ${ }^{\lambda}$, CSCA).

This species is known only from western United States. Given the association with "aborted sugar pine cones", this species is likely a predator on adelgids or Cinara aphids attacking sugar pine, Pinus lambertiana, since they sometimes infest areas at the bases of new cones and can stunt or abort their development. 
[undescribed species (Gaimari 2020: 68)]

Locality: USA: California ( $\$$ specimen, CSCA).

The single specimen is known from the western United States (southern California), but there is no further biological information.

\section{Acknowledgements}

The first author thanks H. Wayne Thornton and Doug Salyer (United States Department of Agriculture, Forest Service) for permission to collect in the National Forests of the Southwestern Region, and to Terry Myers of the Apache-Sitgreaves National Forest, Alpine District, for providing logistical help in the field, and sons Anthony (Tony) and Alexander Gaimari for help with fieldwork on multiple trips. The first author also thanks his late friend and colleague, Vitali Tanasijtshuk (ZISP), for his help and mentorship over the years. We also thank the following curators for providing access to specimens under their care: the late Norman Penny (CAS); James O'Hara and Jeff Cumming (CNC); E. Richard Hoebeke (CUIC); Alfio Raspi (DCDS); the late Donald Webb (INHS); the late Laszlo Papp (HNHM); Adriana Oliva (MACN); Roy Danielsson (MZLU); Ruth Contreras-Lichtenberg and Peter Sehnal (NHMW); Leland Humble (PFCA); Louise Cloutier (QMOR); Carl Olson (UAIC); Allen Norrbom and Wayne Mathis (USNM); Raymond Pupedis, Larry Gall, and Adalgisa Caccone (YPM); the late Vitali Tanasijtshuk (ZISP); and Ben Brugge (ZMAN). In addition, we thank several collectors who provided numerous specimens from their biological studies, including Darrell Ross and his students Sarah Grubin and Glenn Kohler (Oregon State University, Corvallis), and Tonya Bittner (Cornell University, Ithaca, New York). Joanne Klein (Yale University, New Haven Connecticut) helped with molecular lab work. We are particularly grateful to Kevin Barber and Martin Ebejer for their thoughtful and thorough reviews. This paper is based upon previous work supported by the National Science Foundation under DEB Award No. 0075206, as well as a USDA Forest Service agreement 09-CA-156 to the authors and Adalgisa Caccone (Yale University). The findings and conclusions in this publication are those of the authors and should not be construed to represent any official USDA or U.S. Government determination or policy.

\section{References}

Aldrich, J.M. (1925) A new Leucopis from San Francisco. Pan-Pacific Entomologist, 1 (4), 152.

Barriault, S., Soares, A.O., Gaimari, S.D. \& Lucas, E. (2018) Leucopis glyphinivora Tanasijtshuk (Diptera: Chamaemyiidae), a new aphidophagous biocontrol agent; development, survival and comparison with Aphidoletes aphidimyza Rondani (Diptera: Cecidomyiidae). Bulletin of Entomological Research, 109 (4), 472-478. https://doi.org/10.1017/S0007485318000767

Bertone, M.A., Courtney, G.W. \& Wiegmann, B.M. (2008) Phylogenetics and temporal diversification of the earliest true flies (Insecta: Diptera) based on multiple nuclear genes. Systematic Entomology, 33, 668-687. https://doi.org/10.1111/j.1365-3113.2008.00437.x

Blanchard, E.E. (1964) Nuevos predatores de la familia Chamaemyiidae con información sobre otras especies argentinas (Dipt.). Revista de Investigaciones Agropecuarias, Serie 5, Patologia Vegetal, 1, 133-150. [in Spanish]

Cole, F.R. \& Schlinger, E.I. (1969) The Flies of Western North America. University of California Press, Berkeley and Los Angeles, California, 693 pp.

Culliney, T.W., Beardsley Jr., J.W. \& Drea, J.J. (1988) Population regulation of the Eurasian pine adelgid (Homoptera: Adelgidae) in Hawaii. Journal of Economic Entomology, 81, 142-147. https://doi.org/10.1093/jee/81.1.142

Cumming, J.M. \& Wood, D.M. (2009) Adult Morphology and Terminology. In: Brown, B.V., Borkent, A., Cumming, J.M., Wood, D.M., Woodley, N.E. \& Zumbado, M. (Eds.), Manual of Central American Diptera. Vol. 1. NRC Research Press, Ottawa, pp. 9-50.

Czerny, L. (1904) Cremifania nigrocellulata, eine neue Ochthiphiline. Systematische Stellung und Gattungen-Diagnose der Ochthiphilinen. Wiener entomologische Zeitung, 23, 167-170. https://doi.org/10.5962/bhl.part.27205

Czerny, L. (1936) 51. Chamaemyiidae (Ochthiphilidae). In: Lindner E. (Ed.), Die Fliegen der Palaearktischen Region. Vol. 103. E. Schweizerbart'sche Verlagsbuchhandlung, Stuttgart, pp. 1-25.

Dietschler, N.J., Bittner, T.D., Trotter III, R.T., Fahey, T.J. \& Whitmore, M.C. (2021) Biological control of hemlock woolly adelgid: Implications of adult emergence patterns of two Leucopis spp. (Diptera: Chamaemyiidae) and Laricobius nigrinus (Coleoptera: Derodontidae) larval drop. Environmental Entomology, 50 (4), 803-813. 
https://doi.org/10.1093/ee/nvab037

Ebejer, M.J. (2016) The first record of the genus Melanochthiphila Frey (Diptera: Chamaemyiidae) from the Palaearctic, and new data on other Chamaemyiidae from Morocco. Studia dipterologica, 22 (1), 111-120.

Edgar, R.C. (2004) MUSCLE: multiple sequence alignment with high accuracy and high throughput. Nucleic Acids Research, 32, 1792-1797. https://doi.org/10.1093/nar/gkh340

Eichhorn, O. (1968) Problems of the population dynamics of silver fir woolly aphids, genus Adelges (=Dreyfusia), Adelgidae. Zeitschrift für Angewandte Entomologie, 61, 157-214. https://doi.org/10.1111/j.1439-0418.1968.tb03886.x

Gaimari, S.D. (2010) Chamaemyiidae. In: Brown, B.V., Borkent, A., Cumming, J.M., Wood, D.M., Woodley, N.E. \& Zumbado, M. (Eds.), Manual of Central American Diptera. Vol. 2. NRC Research Press, Ottawa, pp. 997-1007.

Gaimari, S.D. (2012) A new genus and species of Chamaemyiidae (Diptera: Lauxanioidea) from South America feeding on Ceroplastes wax scales (Hemiptera: Coccidae), and status of the genus Ortalidina as a chamaemyiid. Zootaxa, 3342 (1), 39-50. https://doi.org/10.11646/zootaxa.3342.1.2

Gaimari, S.D. (2020) Two new genera of Nearctic Chamaemyiidae (Diptera: Lauxanioidea) associated with Cinara aphids (Hemiptera) on Pinus. Zootaxa, 4852 (1), 61-82.

https://doi.org/10.11646/zootaxa.4852.1.3

Gaimari, S.D. (2021 in press) 76. Chamaemyiidae (Silver Flies). In: Kirk-Spriggs, A.H. \& Sinclair, B.J. (Eds.), Manual of Afrotropical Diptera. Vol. 3. Brachycera: Cyclorrhapha, excluding Calyptratae. Suricata 6. African National Biodiversity Institute, Pretoria, pp. 1633-1656.

Gaimari, S.D., Milonas, P. \& Souliotis, C. (2007) Notes on the taxonomy, biology and distribution of Neoleucopis kartliana (Diptera: Chamaemyiidae). Folia Heyrovskyana, Series A, 15, 7-16.

Greathead, D.J. (1995) The Leucopis spp. (Diptera: Chamaemyiidae) introduced for biological control of Pineus sp. (Homoptera: Adelgidae) in Hawaii: implications for biological control of Pineus ?boerneri in Africa. The Entomologist, 114, 83-90.

Grubin, S.M., Ross, D.W. \& Wallin, K.F. (2011) Prey suitability and phenology of Leucopis spp. (Diptera: Chamaemyiidae) associated with hemlock woolly adelgid (Hemiptera: Adelgidae) in the Pacific Northwest. Environmental Entomology, 40 (6), 1410-1416. https://doi.org/10.1603/EN11127

Haliday, A.H. (1833) Catalogue of Diptera occurring about Holywood in Downshire. Entomological Magazine, 1, $147-180$.

Harris, J.W.E. \& Dawson, A.F. (1979) Predator release program for balsam woolly aphid Adelges piceae (Homoptera: Adelgidae) in British Columbia, Canada, 1960-1969. Journal of the Entomological Society of British Columbia, 76, 21-26.

Havill, N.P., Gaimari, S.D. \& Caccone, A. (2018) Cryptic east-west divergence and molecular diagnostics for two species of silver flies (Diptera: Chamaemyiidae: Leucopis) from North America being evaluated for biological control of hemlock woolly adelgid. Biological Control, 121, 23-29. https://doi.org/10.1016/j.biocontrol.2018.02.004

Hebert, P.D.N., Penton, E.H., Burns, J.M., Janzen, D.H. \& Hallwachs, W. (2004) Ten species in one: DNA barcoding reveals cryptic species in the Neotropical skipper butterfly Astraptes fulgerator. Proceedings of the National Academy of Sciences of the United States of America, 101, 14812-14817. https://doi.org/10.1073/pnas.0406166101

Humble, L.M. (1994) Recovery of additional exotic predators of balsam woolly adelgid, Adelges piceae (Ratzeburg) (Homoptera: Adelgidae), in British Columbia. The Canadian Entomologist, 126, 1101-1103. https://doi.org/10.4039/Ent1261101-4

Kohler, G.R., Stiefel, V.L., Wallin, K.F. \& Ross, D.W. (2008) Predators associated with the hemlock woolly adelgid (Hemiptera: Adelgidae) in the Pacific Northwest. Environmental Entomology, 37, 494-504. https://doi.org/10.1093/ee/37.2.494

Krishnaswamy, S. \& Chako, M.J. (1988) Population dynamics of Adelges knucheli and its predators in the north-western Himalayas. I. Host phase: Gallicola. Journal of Biological Control, 2, 92-96.

Malloch, J.R. (1921) Forest insects in Illinois, I. The subfamily Ochthiphilinae (Diptera, Family Agromyzidae). Bulletin of the Illinois Natural History Survey, 13, 347-361. https://doi.org/10.21900/j.inhs.v13.338

Malloch, J.R. (1933) Diptera of Patagonia and South Chile based mainly on material in the British Museum (Natural History). Part VI-Fascicle 4. Acalyptrata (Helomyzidae, Trypetidae, Sciomyzidae, Sapromyzidae, etc. British Museum (Natural History), London, pp. 171-391, 7 pls.

McAlpine, J.F. (1963) Relationships of Cremifania Czerny (Diptera: Chamaemyiidae) and description of a new species. The Canadian Entomologist, 95, 239-253. https://doi.org/10.4039/Ent95239-3

McAlpine, J.F. (1965) Chamaemyiidae. In: Stone, A., Sabrosky, C.W., Wirth, W.W., Foote, R.H \& Coulson, J.R. (Eds.), A catalog of the Diptera of America north of Mexico. USA Department of Agriculture, Agricultural Handbook 276. Agricultural Research Service, U.S. Dept. of Agriculture, Washington, D.C., pp. 706-709. 
McAlpine, J.F. (1971) A revision of the subgenus Neoleucopis (Diptera: Chamaemyiidae). The Canadian Entomologist, 103, $1851-1874$.

https://doi.org/10.4039/Ent1031851-12

McAlpine, J.F. (1977) A remarkable new species of Leucopis from western Canada (Diptera: Chamaemyiidae). Proceedings of the Entomological Society of Washington, 79, 14-18.

McAlpine, J.F. (1978) A new dipterous predator of balsam woolly aphid from Europe and Canada (Diptera: Chamaemyiidae). Entomologica Germanica, 4, 349-355. https://doi.org/10.1127/entom.germ/4/1978/349

McAlpine, J.F. \& Tanasijtshuk, V.N. (1972) Identity of Leucopis argenticollis and description of a new species (Diptera: Chamaemyiidae). The Canadian Entomologist, 104, 1865-1875. https://doi.org/10.4039/Ent1041865-12

McLean, I.F.G. (1982) Three species of Leucopis Meigen (Diptera: Chamaemyiidae) new to Britain. Entomologist's Record and Journal of Variation, 94, 70-72.

Meigen, J.W. (1830) Systematische Beschreibung der bekannten europäischen zweiflügeligen Insekten. Sechster Theil. Schulz, Hamm, xi $+401+[3]$ pp.

Meijere, J.C.H. de (1928) Vierde supplement op de nieuwe nammlijst van nederlandsche Diptera. Tijdschrift voor Entomologie, 71, 11-83. [in Dutch]

Mills, N.J. (1990) Biological control of forest aphid pests in Africa. Bulletin of Entomological Research, 80, 31-36. https://doi.org/10.1017/S0007485300045880

Motley, K., Havill, N.P., Arsenault-Benoit, A.L., Mayfield, A.E., Ott, D.S., Ross, D., Whitmore, M.C. \& Wallin, K.F. (2017) Feeding by Leucopis argenticollis and Leucopis piniperda (Diptera: Chamaemyiidae) from the western USA on Adelges tsugae (Hemiptera: Adelgidae) in the eastern USA. Bulletin of Entomological Research, 107, 699-704. https://doi.org/10.1017/S0007485317000219

Moulton, J.K. \& Wiegmann, B.M. (2004) Evolution and phylogenetic utility of CAD (rudimentary) among Mesozoic-aged Eremoneuran Diptera (Insecta). Molecular Phylogenetics and Evolution, 31, 363-378. https://doi.org/10.1016/S1055-7903(03)00284-7

Neidermeier, A.N., Ross, D.W., Havill, N.P. \& Wallin, K.F. (2020) Temporal asynchrony of adult emergence between Leucopis argenticollis and Leucopis piniperda (Diptera: Chamaemyiidae), predators of the hemlock woolly adelgid (Hemiptera: Adelgidae), with implications for biological control. Environmental Entomology, 49 (4), 823-828. https://doi.org/10.1093/ee/nvaa049

Nguyen, L.-T., Schmidt, H.A., Haeseler, A. von \& Minh, B.Q. (2015) IQ-TREE: A fast and effective stochastic algorithm for estimating maximum-likelihood phylogenies. Molecular Biology and Evolution, 32, 268-274. https://doi.org/10.1093/molbev/msu300

Papp, L. (1979) Korhardéklegyek-Pajzstetülegyek-Lauxaniidae-Chamaemyiidae. Fauna Hungariae, 15 (4), 1-89. [in Hungarian]

Papp, L. (1994) A new Cremifania species from Hungary (Diptera, Chamaemyiidae). Annales Historico-Naturales Musei Nationalis Hungarici, 86, 105-107.

Papp, L. (2010) A new Cremifania species from Bulgaria (Diptera, Cremifaniidae), with a proposal for wing venation terms in higher Diptera. Annales Historico-Naturales Musei Nationalis Hungarici, 102, 193-204.

Rao, V.P. (1965) Final technical report covering the period May 2, 1960 to May 1, 1965. U.S. PL-480 Project: Survey for natural enemies of Adelges spp. attacking silver fir and spruce in the Himalayas. Commonwealth Institute of Biological Control, India Station, Bangalore, $85 \mathrm{pp}$.

Rao, V.P. \& Ghani, M.A. (1972) Studies on predators of Adelges spp. in the Himalayas. Commonwealth Agricultural Bureaux, Farnham Royal, Slough, England. Miscellaneous Publication, 3, 1-116.

Raspi, A. (2008) Order Diptera, family Chamaemyiidae. Arthropod Fauna of the UAE, 1, 662-665.

Ratzeburg, J.T.C. (1844) Die Forst-Insecten oder Abbildung und Beschreibung der in den Wäldern Preussens und der Nachbarstaaten als schädlich oder nützlich bekannt gewordenen Insecten; in systematischer Folge und mit besonderer Rücksicht auf die Vertilgung der Schädlichen. Vol. 3. Die Ader-, Zwei-, Halb-, Netz- und Geradflügler. Nicolai, Berlin, vii +314 pp., 16 pls.

Rondani C. (1848) Osservazioni sopra parecchie specie di esapodi afidicidi e sui loro nemici [part]. Nuovi Annali delle Scienze Naturali e Rendiconto delle Sessioni della Società Agraria e dell'Accademia delle Scienze dell'Instituto di Bologna, Serie 2, 8 [1847], 337-351, 432-448.

Ross, D.W., Gaimari, S.D., Kohler, G.R., Wallin, K.F. \& Grubin, S.M. (2011) Chamaemyiid predators of the hemlock woolly adelgid from the Pacific Northwest. In: Reardon, R. \& Onken, B. (Eds.), Implementation and Status of Biological Control of the Hemlock Woolly Adelgid. U.S. Forest Service, Publication FHTET-2011-04. U.S. Forest Service, Morgantown, West Virginia, pp 97-106

Sano, M., Tabuchi, K. \& Ozaki, K. (2008) A holocyclic life cycle in a gall-forming adelgid, Adelges japonicus (Homoptera: Adelgidae). Journal of Applied Entomology, 132, 557-565. https://doi.org/10.1111/j.1439-0418.2008.01299.x

Sluss, T.P. \& Foote, B.A. (1973) Biology and immature stages of Leucopis pinicola and Chamaemyia polystigma (Diptera: Chamaemyiidae). The Canadian Entomologist, 105, 1443-1452. 
https://doi.org/10.4039/Ent1051443-11

Talavera, G., Lukhtanov, V., Pierce, N.E. \& Vila, R. (2021) DNA barcodes combined with multilocus data of representative taxa can generate reliable higher-level phylogenies. Systematic Biology, syab038. [published online] https://doi.org/10.1093/sysbio/syab038

Tanasijtshuk, V.N. (1958) New species of the genus Leucopis (Diptera, Chamaemyiidae) from Leningrad region. Trudy Zoologicheskogo Instituta, 24, 89-98. [in Russian]

Tanasijtshuk, V.N. (1962) New and little-known species of the genus Leucopis (Diptera, Chamaemyiidae) from the European part of the USSR. Entomologicheskoye Obozreniye, 41, 220-229. [in Russian; English translation: (1962) Entomological Review, 41, 132-138]

Tanasijtshuk, V.N. (1966) New species of the genus Leucopis (Diptera, Chamaemyiidae) from south-western Kazakhstan. Trudy Zoologicheskogo Instituta Akademii Nauk SSSR, 37, 233-236. [in Russian]

Tanasijtshuk, V.N. (1968) Species of Leucopis (Diptera, Chamaemyiidae) from India. Bulletin of Entomology, Madras, 9, 612.

Tanasijtshuk, V.N. (1986) [Silver-flies (Chamaemyiidae)]. Fauna of the USSR. New Series 134. Dipterans. Vol. 14. Zoological Institute of the Russian Academy of Sciences, Nauka Publishers, St Petersburg, 335 pp. [in Russian]

Tanasijtshuk, V.N. (1997) A new Holarctic genus of Chamaemyiidae (Diptera). International Journal of Dipterological Research, $8(2), 113-116$.

Tanasijtshuk, V.N. (2001) On two sister species of the genus Anchioleucopis Tanasijtshuk, 1997 (Diptera, Chamaemyiidae) from the Holarctic region. Entomologicheskoye Obozreniye, 80 (4), 901-907. [in Russian; English translation: (2001) Entomological Review, 81 (5), 542-547]

Tanasijtshuk, V.N. (2002) Studies on Nearctic species of Leucopis (Diptera: Chamaemyiidae). I. The redescription of Nearctic Leucopis published before 1965. Zoosystematica Rossica, 11, 193-207.

Tanasijtshuk, V.N. (2003) Studies on Nearctic species of Leucopis (Diptera: Chamaemyiidae). II. New species. Zoosystematica Rossica, 11, 375-396.

Tanasijtshuk, V.N. (2005) Studies on Nearctic species of Leucopis (Diptera: Chamaemyiidae). III. L. annulipes Zetterstedt and a new sibling species from the Nearctic. Zoosystematica Rossica, 13 (2), 233-238.

Tanasijtshuk, V.N. (2006) Studies on Nearctic species of Leucopis (Diptera: Chamaemyiidae). IV. New species. Zoosystematica Rossica, 14 (2), 281-288. https://doi.org/10.31610/zsr/2005.14.2.281

Thunes, K.H., Skartveit, J., Gjerde, I., Stary, J., Solhoy, T., Fjellberg, A., Kobro, S., Nakahara, S., zur Strassen, R., Vierbergen, G., Szadziewski, R., Hagan, D.V., Grogan Jr., W.L., Jonassen, T., Aakra, K., Anonby, J., Greve, L., Aukema, B., Heller, K., Michelsen, V., Haenni, J.-P., Emeljanov, A.F., Douwes, P., Berggren, K., Franzen, J., Disney, R.H.L., Prescher, S., Johanson, K.A., Mamaev, B., Podenas, S., Andersen, S., Gaimari, S.D., Nartshuk, E., Søli, G.E.E., Papp, L., Midtgaard, F., Andersen, A., Tschirnhaus, M. von, Bächli, G., Olsen, K.M., Olsvik, H., Foldvari, M., Raastad, J.E., Hansen, L.O. \& Djursvoll, P. (2004) The arthropod community of Scots pine (Pinus sylvestris L.) canopies in Norway. Entomologica Fennica, 15, 65-90.

Viggiani, G. \& Mustica, L. (2008) Some notes on the biological control of insect pests in the island of Ischia. Bollettino del Laboratorio di Entomologia Agraria Filippo Silvestri, 62, 79-82.

Wantuch, H.A., Havill, N.P., Hoebeke, E.R., Kuhar, T.P. \& Salom, S.M. (2019) Predators associated with the pine bark adelgid (Hemiptera: Adelgidae), a native insect in Appalachian forests, United States of America, in its southern range. The Canadian Entomologist, 151 (1), 73-84. https://doi.org/10.4039/tce.2018.53

Wilson, F. (1938) Notes on the insect enemies of chermes with particular reference to Pineus pini, Koch, and P. strobi, Hartig. Bulletin of Entomological Research, 29, 373-389. https://doi.org/10.1017/S0007485300026286

Zetterstedt, J.W. (1848) Diptera Scandinaviae disposita et descripta. Tomus septimus. Officina Lundbergiana, Lundae [=Lund], pp. 2581-2934.

Zetterstedt, J.W. (1855) Diptera Scandinaviae disposita et descripta. Tomus duodecimus seu supplementum tertium, continens addenda, corrigenda \& emedanda tomis undecim prioribus. Officina Lundbergiana, Lundae [=Lund], pp. $\mathrm{i}-\mathrm{xx}+4547-$ 4942.

Zondag, R. \& Nuttall, M.J. (1989) Pineus laevis (Maskell), pine twig chermes or pine woolly aphid (Homoptera: Adelgidae). In: Cameron, P.J., Hill, R.L., Bain, J. \& Thomas, W.P. (Eds.), Review of Biological Control of Invertebrate Pests and Weeds in New Zealand 1874 to 1987. CAB International Institute of Biological Control, Wallingford, Oxon, pp. $295-297$. 